UNIVERSIDADE DE SÃO PAULO

FACULDADE DE ECONOMIA, ADMINISTRAÇÃO E CONTABILIDADE DEPARTAMENTO DE ADMINISTRAÇÃO

PROGRAMA DE PÓS GRADUAÇÃO EM EMPREENDEDORISMO

RENOVAÇÃO DE PROCESSOS OPERACIONAIS NA EFICIÊNCIA DO ATENDIMENTO AO USUÁRIO EM UNIDADES DE SAÚDE EXTRAHOSPITALARES

Andrea Castelli

Orientador:

Prof. Dr. Antonio Geraldo da Rocha Vidal

SÃO PAULO 
Prof. Dr. Vahan Agopyan

Reitor da Universidade de São Paulo

\author{
Prof. Dr. Fábio Frezatti
}

Diretor da Faculdade de Economia, Administração e Contabilidade

Prof. Dr. Moacir de Miranda Oliveira Júnior

Chefe do Departamento de Administração

Prof. Dr. Marcelo Caldeira Pedroso

Coordenador do Programa de Mestrado Profissional em Empreendedorismo 


\title{
RENOVAÇÃO DE PROCESSOS OPERACIONAIS NA EFICIÊNCIA DO ATENDIMENTO AO USUÁRIO EM UNIDADES DE SAÚDE EXTRA- HOSPITALARES
}

\author{
Dissertação apresentada ao Programa de Pós- \\ Graduação em Mestrado Profissional em \\ Empreendedorismo do Departamento de \\ Administração da Faculdade de Economia, \\ Administração e Contabilidade da Universidade de \\ São Paulo, como requisito parcial para obtenção do \\ título de Mestre em Ciências
}

Orientador: Prof. Dr. Antonio Geraldo da Rocha Vidal Versão Corrigida

SÃO PAULO 
Catalogação na Publicação (CIP)

Ficha Catalográfica com dados inseridos pelo autor

CASTELLI, ANDREA.

RENOVAÇÄO DE PROCESSOS OPERACIONAIS NA EFICIÊNCIA DO ATENDIMENTO AO USUARIO EM UNIDADES DE SAÚDE EXTRA HOSPITALARES / ANDREA CASTELLI. - Săo Paulo, 2019.

$111 \mathrm{p}$.

Dissertaçāo (Mestrado) - Universidade de São Paulo, 2019.

Orientador: ANTONIO GERALDO DA ROCHA VIDAL.

1. Administração de serviços de saúde . 2. Assistência à saúde. 3 .

Saúde. 4. Serviços de saúde . I. Universidade de São Paulo. Faculdade de Economia, Administração e Contabilidade. II. Título. 
Ao meu esposo, André, por me inspirar todos os dias.

Aos meus pais, José e Elenice, por terem me dado a vida e os princípios que me conduziram até aqui.

Aos meus irmãos e cunhadas, importantes parceiros de vida.

Ao meu sobrinho, Gio, minha fonte de alegria. 


\section{AGRADECIMENTOS}

Ao meu orientador, Antonio Geraldo da Rocha Vidal, por ter compartilhado tanto conhecimento com carinho e paciência.

Aos colegas do mestrado profissional, pessoas brilhantes que me inspiraram e contribuíram para ampliar meus horizontes profissionais.

À Fabi, secretária do MPE, guardiã dos prazos e regras, sem ela tudo seria mais difícil.

Aos professores da FEA, em especial ao Marcelo Pedroso, atual coordenador do curso, que me incentivou a trilhar essa jornada de conhecimento e pesquisa em um bate-papo despretensioso em 2016. 
"Ninguém chegou a ser sábio por acaso" Sêneca 


\section{RESUMO}

Ao se analisar a cadeia de valor do segmento de saúde, nota-se a existência de inúmeros atores, cuja atuação nem sempre acontece de forma sinérgica, tornando complexa a gestão e a geração de valor ao usuário. Pode-se considerar que a somatória das interações do usuário com o sistema, dispostas em uma linha do tempo, resulta em uma jornada do seu relacionamento com o sistema de saúde. Atendendo a premissa de vincular a experiência do pesquisador à um projeto de pesquisa com foco em inovação e empreendedorismo, por meio de uma pesquisa descritiva, de abordagem qualitativa em uma pesquisa-ação, esse trabalho se propõe a responder a seguinte questão de pesquisa: como melhorar os processos operacionais de atendimento ao usuário em uma prestadora de serviços de saúde? Foram revisadas atividades, pessoas e estrutura da central de atendimento telefônico, e o resultado após a implementação do projeto demonstrou um aumento do registro de atendimentos no sistema de informação de 100,1\% e uma diminuição de 47,5\% no tempo médio de atendimento ao usuário. Através das ações empreendidas, foi possível concluir que este estudo contribuiu para uma melhoria na eficiência do atendimento ao usuário, gerando uma contribuição efetiva para a empresa estudada.

Palavras chaves: Gestão de Processos, Prestação de Serviços em Saúde, Eficiência Operacional 


\section{ABSTRACT}

When analyzing the value chain of the health segment, one notices the existence of numerous actors, whose performance does not always happen synergistically, making management and the generation of value to the user complex. It can be considered that the sum of user interactions with the system, arranged in a timeline, results in a journey of their relationship with the health system. Given the premise of linking the researcher's experience to a research project focused on innovation and entrepreneurship, through a descriptive research, qualitative approach in an action research, this paper aims to answer the following research question: how to improve Operational processes for user care at a healthcare provider? Activities, people and structure of the call center were reviewed, and the result after project implementation showed a $100.1 \%$ increase in information system enrollment and a $47.5 \%$ decrease in average customer service time. It is concluded that this study contributed to an improvement in the efficiency of user service, generating an effective contribution to the studied company.

Keyword: Process Management, Health Service Delivery, Operational Efficiency 


\section{LISTA DE ABREVIATURAS E SIGLAS}

ABPMP - Association Of Business Process Management Professionals International ANS - Agência Nacional de Saúde

APH - Atendimento Pré-Hospitalar

ARM - Auxiliares de Regulação Médica

BPM - Business Process Management

CHA - Conhecimento, Habilidade e Atitude

CPF - Cadastro de Pessoa Física

DCNT - Doenças Crônicas Não Transmissíveis

EBITDA - Earnings before interest, taxes, depreciation and amortization. Em português, "Lucros antes de juros, impostos, depreciação e amortização"

ERP - Enterprise Resource Planning

MFP - Mecanismo da Função Produção

NEAD - Núcleo de Empresas de Atenção Domiciliar

NF - Nota Fiscal

NPS - Net Promoter Score

OS - Ordem de Serviço

PAD - Plano de Assistência Domiciliar

PDCA - Plan, Do, Check, Act

RFP - Request For Proposal

RJ - Rio de Janeiro

SADT - Serviço de Apoio a Diagnose e Terapia 
SAMU - Serviço de Atendimento Móvel de Urgência

SIV - Suporte Intermediário de Vida

SLA - Service Level Agreement

SP - São Paulo

SUS - Sistema Único de Saúde

URA - Unidade de Resposta Audível

UTI - Unidade de Tratamento Intensivo 


\section{LISTA DE FIGURAS}

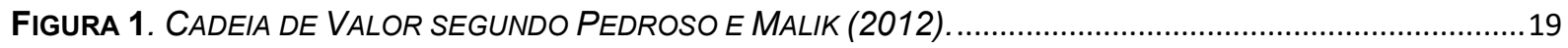

FIGURA 2. APRESENTAÇÃO DO ESTUDO. FONTE: ELABORADO PELA AUTORA. ..............................................2

FIGURA 3 ABORDAGEM DE APLICAÇÃO DE BPM (BUSINESS PROCESS MANAGEMENT, EM PORTUGUÊS,

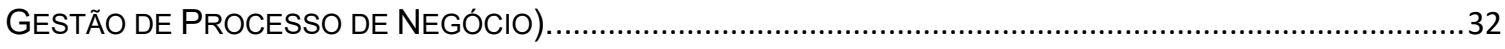

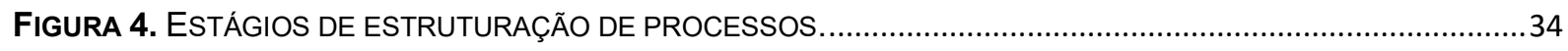

FIGURA 5. O QUE FALTA EM CADA ESTÁGIO PARA UMA GESTÃO BASEADA EM PROCESSOS. ...............................35

FIGURA 6. ESTRUTURA PARA CONDUÇÃO DE PESQUISA-AÇÃO....................................................................4

FIGURA 7. TAXA DE SINISTRALIDADE DAS OPERADORAS DE PLANOS DE SAÚDE NO BRASIL.............................4

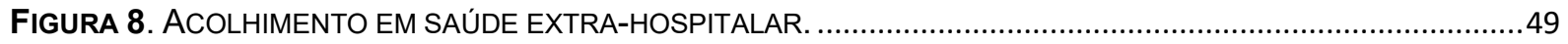

FIGURA 9. METODOLOGIA DE DESENVOLVIMENTO DO DIAGNÓSTICO. ..........................................................

FIGURA 18. NOVO MODELO DE ATENDIMENTO AO USUÁRIO. FONTE: ELABORADO PELA AUTORA. ......................81

FIGURA 19. OPORTUNIDADES DE MELHORIA NOS SISTEMAS DE SUPORTE DIAGNOSTICADAS PELA

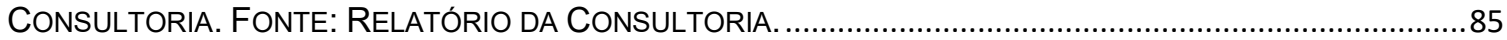

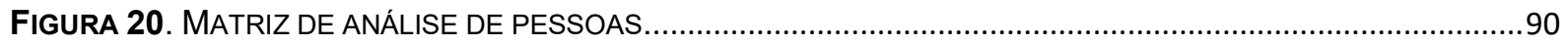

FIGURA 21. ESTRUTURA ATUAL DAS ÁREAS. FONTE: ELABORADA PELA AUTORA. ..........................................93

FIGURA 22. ESTRUTURA PROPOSTA APÓS A REVISÃO DAS ATIVIDADES. FONTE: ELABORADA PELA AUTORA....94 


\section{LISTA DA TABELAS}

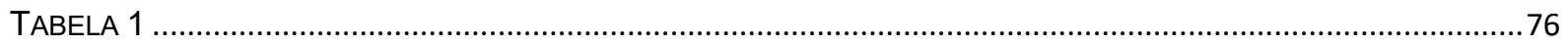

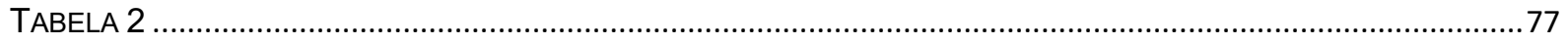

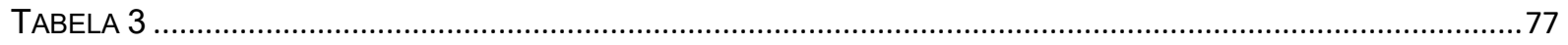

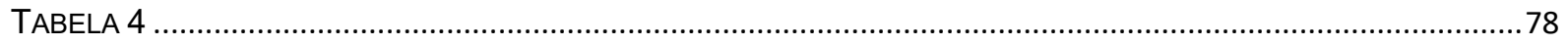

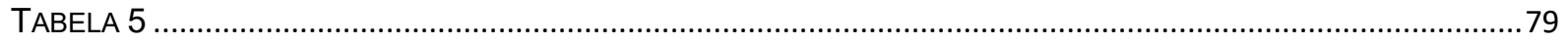

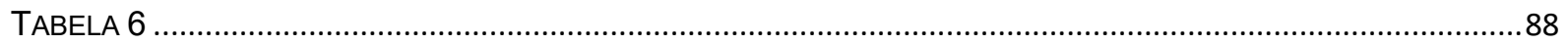

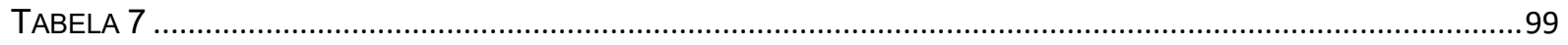

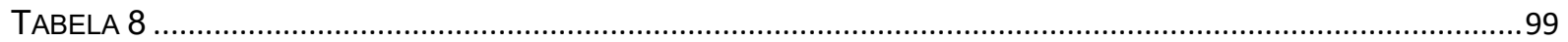

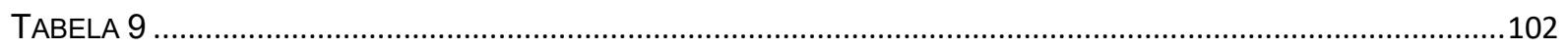

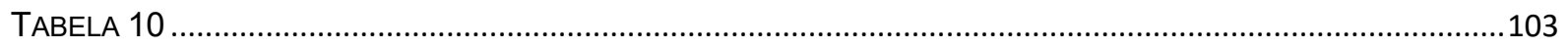

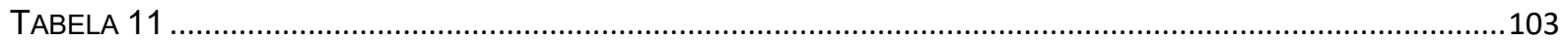




\section{SUMÁRIO}

$\begin{array}{lr}\text { 1. Introdução } & 16\end{array}$

$\begin{array}{ll}1.1 \text { Contexto do sistema de saúde } & 16\end{array}$

1.2 Cadeia de Valor em Saúde $\quad 17$

1.3 Prestação de serviços em saúde $\quad 20$

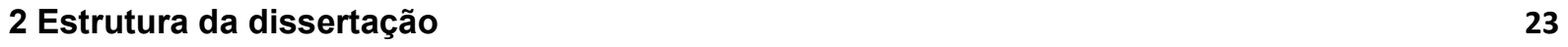

$\begin{array}{lr}3 \text { Justificativas do estudo } & 24\end{array}$

4 Objetivos e resultados esperados $\quad 26$

$\begin{array}{lr}5 \text { Referencial teórico } & 28\end{array}$

$\begin{array}{ll}5.1 \text { Eficiência Operacional } & 28\end{array}$

5.2 Gestão por processos de negócios $\quad 30$

5.3 Gestão Organizacional $\quad 36$

5.3.1 Estrutura Organizacional $\quad 36$

$\begin{array}{ll}\text { 5.3.2 Competências } & 38\end{array}$

6 Método de Pesquisa $\quad 39$

$\begin{array}{ll}6.1 \text { Contexto } & 39\end{array}$

6.2 Abordagem da pesquisa $\quad 39$

$\begin{array}{ll}6.3 \text { Pesquisa Ação } & 41\end{array}$

7 Planejamento da pesquisa $\quad 45$

7.1 Entendimento do problema $\quad 45$

7.2 Planejamento das ações $\quad 49$

8 Coleta de Dados $\quad 51$

8.1 Diagnóstico da Consultoria $\quad 51$

9 Implementação das ações $\quad \mathbf{5 4}$

9.1 Análise dos processos operacionais de atendimento 54

9.1.1 Transporte terrestre de usuários $\quad 55$

9.1.2 Programas de Gerenciamento de doenças crônicas $\quad 61$

9.1.3 Internação domiciliar $\quad 67$

9.2 Proposta para o novo processo de atendimento ao usuário 79

9.3 Implementação da central de atendimento 82

9.3.1 Novo sistema de telefonia $\quad 83$

9.3.2 Revisão do Sistema de Informação $\quad 84$

9.3.3 Revisão das atividades $\quad 86$

9.3.4 Reestruturação da equipe de atendimento 88

9.3.5 Revisão da estrutura organizacional 89

10 Avaliação dos Resultados $\quad 98$

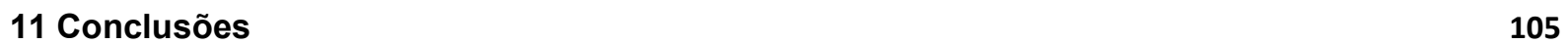




\section{Introdução}

\subsection{Contexto do sistema de saúde}

O sistema de saúde é composto por um conjunto de instituições que trabalham de forma complementar umas às outras no atendimento ao usuário final, que é, muitas vezes, denominado paciente.

Do ponto de vista da oferta de valor, pode-se dividir o sistema em empresas de prestação de serviços, empresas fabricantes de insumos e compradores de serviços e insumos (Burns et al, 2002).

Do ponto de vista do financiamento, o sistema brasileiro pode ser dividido em dois setores: o setor público, situação na qual o financiamento parte do Estado e pode ser subdividido nas esferas Federal, Estadual e Municipal; e o setor privado, também conhecido como saúde suplementar, cujo financiamento provém das empresas e pessoas físicas que sustentam os planos e seguros privados de saúde. $\mathrm{O}$ acesso ao setor privado normalmente tem relação direta com a capacidade de pagamento do cidadão. Ainda que se trate de sistemas distintos (público e privado), eles se conectam, havendo o reembolso do sistema privado para parte dos atendimentos públicos (Paim, Travassos, Almeida, Bahia, \& Macinko, 2011).

Esta pesquisa transcorre na esfera das empresas prestadoras de serviços que são remuneradas por planos e seguros privados da saúde suplementar. O foco se dará no processo de atendimento aos usuários, buscando a oferta de um serviço mais eficiente e de melhor qualidade percebida.

Nos próximos tópicos, pretende-se localizar melhor esse estudo dentro desse sistema tão complexo que é o da saúde. 


\subsection{Cadeia de Valor em Saúde}

Segundo Christensen et al (2009), entende-se como rede de valor a forma como uma empresa estabelece seu modelo de gestão, que inclui a sua relação com a cadeia de fornecedores, parceiros e distribuidores, de forma que o trabalho integrado traga lucro e atenda a um determinado segmento de consumidores.

Analisando a cadeia de valor do segmento de saúde, nota-se a existência de inúmeros atores, cuja atuação nem sempre acontece de forma sinérgica, tornando complexa a gestão e a geração de valor ao usuário. Esse tema foi alvo de pesquisa de uma série de autores que buscaram analisar oportunidades de atuação nesse segmento, contribuindo para o setor de saúde de uma forma geral.

Uma análise da produção sobre o tema 'cadeia de valor' dentro do sistema americano de saúde permite destacar os autores e suas respectivas linhas de pesquisa:

- Burns et al (2002) considera cinco elos na cadeia de valor (financiadores, intermediadores financeiros, prestadores de serviços, fabricantes de insumos e compradores);

- Christensen et al (2009) destaca 12 elementos nessa cadeia e propõe um modelo disruptivo que reconfigure a relação entre esses agentes;

- Herzlinger (2007) propõe que a cadeia seja impulsionada pelas forças do mercado e pelo desejo do consumidor, sendo suportada por um prontuário eletrônico pessoal único e sistemas de avaliação de desempenho para os prestadores de serviços;

- Pisano (2006) analisa a cadeia de saúde partindo do setor de biotecnologia;

- Porter e Teisberg (2006) analisaram a cadeia de valor da saúde sob a ótica da estratégia competitiva.

No Brasil, podem ser citados três autores que investigaram esse tema: 
- Campos et al (2009) divide os participantes dessa cadeia em 10 grupos: (1) Planos de saúde (2), Profissionais da saúde, incluindo médicos, (3) Hospitais, (4) Serviços de apoio ao diagnóstico e terapia SADT, (5) Indústria Farmacêutica, (6) Distribuidores de medicamentos, (7) Farmácias, (8) Indústria de insumos, (9) Distribuidores de equipamentos e materiais, (10) Serviços Governamentais. O usuário final, comumente chamado de paciente, ocupa o centro dessa cadeia, uma vez que os autores o veem como a razão dessa cadeia existir;

- Gadelha (2003) criou um modelo conceitual denominado complexo industrial da saúde, enquadrando os agentes na indústria de base química, indústria de base mecânica e prestadores de serviços de saúde;

- Pedroso e Malik (2012) combinaram os conceitos anteriores e propuseram um novo modelo de cadeia de valor contendo seis elos verticais e três elos horizontais, suportados por quatro fluxos de valor. 


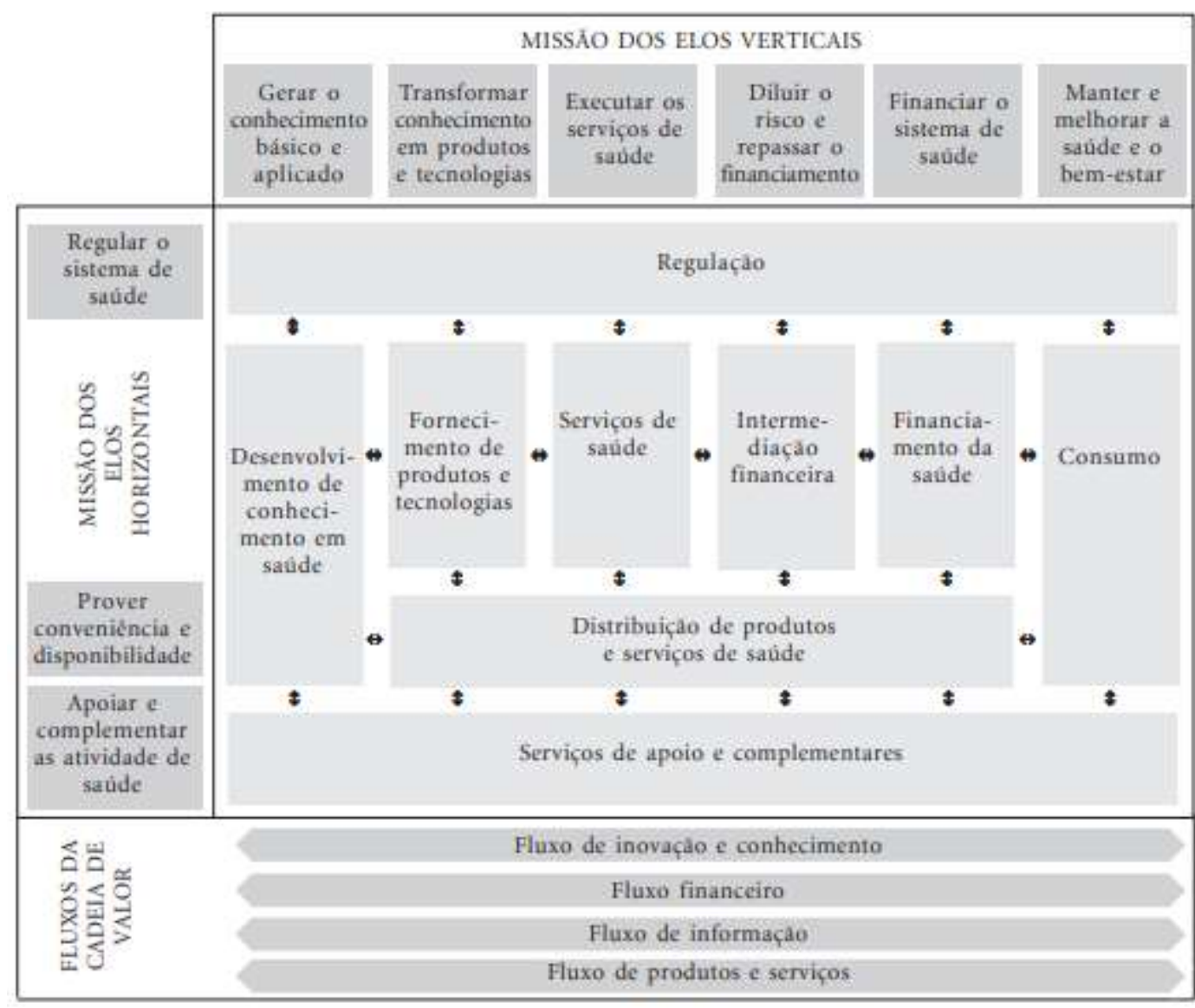

Figura 1. Cadeia de Valor segundo Pedroso e Malik (2012).

Esses autores ressaltam a importância da pesquisa e do desenvolvimento dentro desse setor, propondo um modelo que parta da geração de conhecimento e que produza uma cascata de ações que o transformem em produtos e tecnologias até atingir o usuário final, com ações de manutenção ou ampliação de qualidade de vida e bem-estar. Os elos horizontais dessa cadeia destacam a atuação do sistema regulatório em todas as áreas do conhecimento, a cadeia de distribuição dos produtos e serviços e os serviços complementares que apoiam o sistema como um todo.

O direcionamento dos investimentos em pesquisa entre as diversas áreas na saúde advém tanto das estratégias das várias empresas envolvidas nesse sistema, quanto da força da sociedade civil em direcionar esforços para as questões que garantam acesso e equidade. Nem sempre os benefícios são endereçados aos grupos de maior vulnerabilidade. Pode-se, então, delimitar as pesquisas e inovações em saúde como uma construção econômica, institucional e política, para as quais 
convergem fortes interesses. O Estado assume uma posição importante como regulador desse sistema, garantindo a preservação do interesse da população ao não permitir que a lógica econômica privada seja prioritária em relação às necessidades da sociedade. (Gadelha, 2003)

\subsection{Prestação de serviços em saúde}

As empresas prestadoras de serviço em saúde, dentro da cadeia de valor proposta por Pedroso e Malik (2012), sofrem influência do elo da intermediação financeira e devem se adequar às suas regras de atuação. Além disso, consomem insumos das distribuidoras de produtos e tecnologia para executar suas atividades junto ao usuário final. Sua principal finalidade consiste em organizar e orquestrar recursos humanos, materiais e conhecimento, visando à oferta de um atendimento de qualidade e seguro para o paciente.

Estão enquadradas na categoria de prestadores de serviços, instituições como hospitais, empresas de assistência domiciliar, clínicas multiprofissionais, laboratórios, empresas de promoção à saúde e gerenciamento de doentes crônicos, além de transporte de usuários.

Essas empresas interagem com o usuário do serviço de diferentes formas e em diferentes contextos, dependendo da demanda de saúde apresentada por ele. As interações podem ser pontuais e únicas, como, por exemplo, na administração de uma vacina; ou contínuas e longas, como no caso de internações ou tratamento de doenças crônicas.

A somatória dessas interações, dispostas em uma linha do tempo, resulta em uma jornada de relacionamento do usuário com o sistema de saúde.

Pode-se considerar a experiência do usuário como a resultante do seu relacionamento com o sistema de saúde. Segundo Rodrigues (2019), experiência e a satisfação do usuário são conceitos distintos. Enquanto a satisfação está relacionada à expectativa atendida, a experiência inclui aspectos como acesso à informação, 
forma como as suas solicitações são tratadas, respeito em todas as etapas do atendimento, sentir-se ouvido e, portanto, participante das decisões, e ter seus valores individuais respeitados.

Sob esse aspecto, as instituições de saúde que pretendam interferir na experiência dos seus usuários de forma positiva precisam se preocupar não só com a adequada capacitação técnica da equipe e da disponibilização de recursos diagnósticos e terapêuticos, mas também com aspectos como capacidade de comunicação e empatia.

Essas empresas podem ser classificadas por tipo de atendimento, a saber:

- Ambulatorial (situação na qual a prestação de serviço é voltada para atender usuários que necessitem ser avaliados por algum profissional de saúde com habilitação, como médicos, psicólogos, enfermeiros, entre outros);

- Internação (situação na qual a prestação de serviço tenha capacidade de ofertar um leito hospitalar para permanência mínima de 24 horas);

- Serviço de Apoio a Diagnose e Terapia (SADT) - situação na qual a prestação de serviço tem como objetivo o diagnóstico ou o apoio à continuidade do tratamento ao usuário);

- Urgência (situação na qual a prestação de serviço tem como alvo o atendimento ao usuário com risco iminente de vida, com o objetivo de minimizar possíveis danos) e,

- Vigilância Epidemiológica e/ou Sanitária e Farmácia ou Cooperativa. (Ministério da Saúde, 19/12/2005, Portaria 741).

Uma outra forma de classificá-las seria por nível de complexidade clínica de usuários atendidos, que determina o nível de especialização da oferta. Nesse caso, o sistema é dividido em atenção primária, secundária e terciária:

- A atenção primária é constituída por estabelecimentos cujo foco se dá nos atendimentos de baixa complexidade. Pode-se enquadrar nessa categoria os consultórios e clínicas, ambulatórios de clínica médica e saúde da família, além de serviços de promoção à saúde e gerenciamento de doenças crônicas. 
- A atenção secundária abarca um nível de maior complexidade e especialização. Nessa categoria, pode-se agrupar os ambulatórios e clínicas de especialidade, serviços de apoio ao diagnóstico e terapia (SADT), serviços de urgência e emergência e hospitais gerais.

- A atenção terciária tem foco no atendimento de maior complexidade e, por essa razão, também é oferecida por instituições altamente especializadas. Aqui, encontram-se os hospitais especializados em determinados segmentos, como centros de atendimento ao câncer, centros de ortopedia ou hospitais que segmentam sua prestação de serviços nos subsistemas anatômicos, criando pequenos centros de especialidade dentro da mesma planta física. (Cohn e Elias, 2003) 


\section{Estrutura da dissertação}

O presente estudo está subdividido em cinco partes, conforme demonstrado na Figura 2.

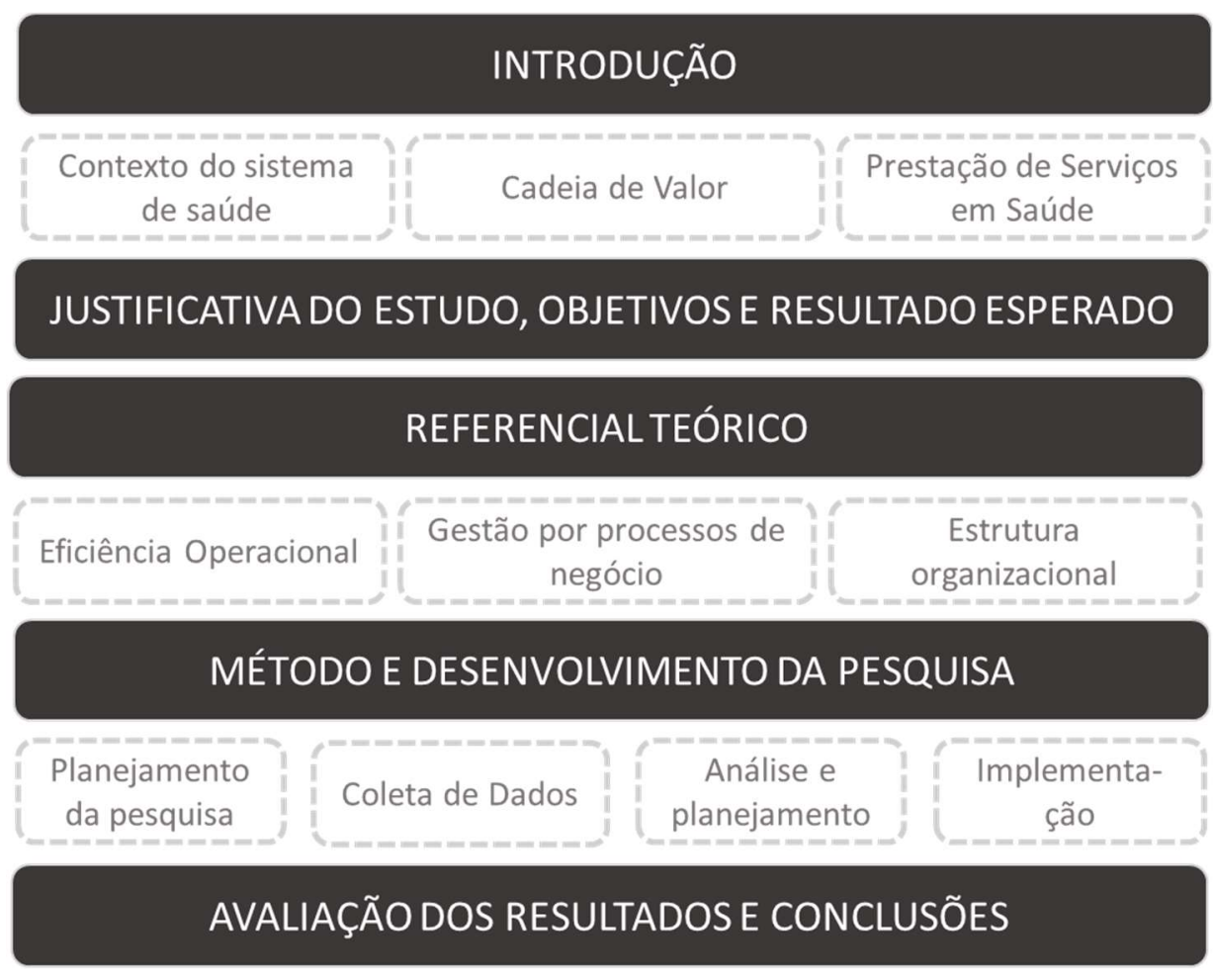

Figura 2. Apresentação do Estudo. Fonte: elaborado pela autora.

A partir de todo um contexto do sistema de saúde e da problemática encontrada pela autora, definem-se os objetivos da pesquisa e quais são os resultados esperados com relação a sua execução. Uma vez definidos os objetivos e os resultados esperados, o capítulo seguinte apresenta a visão de vários autores sobre o tema em questão, embasando teoricamente a pesquisa. Finalmente, é exposto o método científico escolhido e seu desenvolvimento, bem como as conclusões que a autora pôde alcançar. 


\section{Justificativas do estudo}

O presente trabalho nasceu da inquietação da autora, que, dentro da sua trajetória profissional, viveu o dia a dia de empresas de vários segmentos da cadeia da saúde (hospitais, clínica de longa permanência, assistência domiciliar, gestão de doentes crônicos, operadoras de planos de saúde, gestão de benefício farmácia e serviços de remoção e APH). Ainda que houvesse muitas diferenças entre elas, como posicionamento estratégico, proposta de valor e tipo de prestação de serviço, uma questão era comum a todas: como poderiam contribuir para um atendimento mais efetivo ao usuário do ponto de vista de custo e qualidade?

A resposta a essa questão não é simples. Isso porque essas empresas fazem parte de um sistema que é considerado complexo, possuindo um grande número de agentes em interação, exibindo comportamentos emergentes, não triviais e com autoorganização (Michell, 2009).

Considerando a imensa gama de possibilidades de pesquisa dentro do mercado da saúde, a opção pelo foco deste estudo partiu do desafio profissional da autora. Como Executiva de uma empresa que atua no ramo de prestação de serviços extra-hospitalares na área de saúde, seu principal desafio, imposto em função do diagnóstico da consultoria, foi o de atuar em um projeto de reestruturação da companhia, que passava por grande crise. Seu maior foco seria na busca por eficiência, identificando oportunidades de melhoria de processos, o que teria como efeito a diminuição dos custos, sem perder de vista a qualidade do atendimento e a segurança do usuário atendido.

Ainda era necessário definir o ponto de partida, uma vez que inúmeros processos demonstravam grandes oportunidades de ganhos. A decisão de atuar na renovação do processo de atendimento aos usuários da assistência domiciliar partiu da lógica de que, ali, seria possível interagir com todos os stakeholders dessa cadeia (clientes, usuários, fornecedores e funcionários), organizar as demandas da operação que concentra $65 \%$ do faturamento da empresa, e concentrar as demandas 
provenientes dessa cadeia em um único canal, facilitando a captura de informações e atuação nas demandas de maior custo.

Esse foco de pesquisa ganhou ainda mais relevância quando foi traçado um paralelo entre o microambiente da empresa e o macroambiente do sistema de saúde: ambos necessitam de uma nova forma de organização, propiciando um ambiente que explore o máximo potencial individual de todos os agentes, num sistema que permita a integração entre e todos e, acima de tudo, gerando resultados que melhorem o valor para o cliente e, consequentemente, para o usuário, trazendo sustentabilidade financeira para o setor e maior percepção de qualidade para quem utiliza o sistema.

Esse estudo certamente não tem a pretensão de esgotar todas as possibilidades de atuação e resolver os problemas que circundam esse sistema, mas se propõe, com base em um estudo de caso, a ser um agente de mudança, inovação e base para futuros estudos. 


\section{Objetivos e resultados esperados}

O objetivo deste estudo é a estruturação do canal de recebimento das demandas da assistência domiciliar através da renovação dos processos operacionais de atendimento ao usuário.

Para atingir o objetivo principal, há que se alcançar os objetivos específicos:

- Analisar os processos operacionais de atendimento aos usuários dos serviços da empresa;

- Identificar as desconexões e oportunidades de remodelagem, definição de indicadores de desempenho e redução de desperdícios nos processos de atendimento aos usuários;

- Remodelagem dos processos operacionais de atendimento aos usuários;

- Analisar a implementação dos processos remodelados;

- Avaliar e Monitorar os resultados alcançados.

Espera-se, com essa pesquisa aplicada:

- Possibilitar a produção de indicadores que permitam uma análise do ponto de vista de custo e efetividade, buscando apoiar a empresa a se tornar sustentável;

- Aumentar a eficiência operacional, medida por meio de relatórios e indicadores produzidos pelos sistemas de informação, comparando o volume total da equipe disponível para atendimento antes e depois da implementação do projeto;

- Especificação de requisitos de informação para os Sistemas de Informação para Apoio aos novos processos;

Pretende-se responder a seguinte questão de pesquisa: como melhorar os processos operacionais de atendimento ao usuário de forma a se obter os seguintes resultados: 
- Aumento da eficiência - reduzindo o tempo de resposta para as solicitações dos usuários;

- Diminuição de custo - reduzindo o retrabalho e o custo com pessoal envolvido diretamente no atendimento ao usuário

- Aumento da satisfação do usuário - medida por diminuição nos apontamentos para a Ouvidoria 


\section{Referencial teórico}

O conhecimento teórico indica uma direção que tenha maior probabilidade de produzir resultados de valor. Ele tem uma grande importância para a primeira etapa do processo de pesquisa, pois trará o norte necessário para que ela se desenvolva. $\mathrm{A}$ teoria bem aplicada garante a entrega de resultados úteis ao término do processo de pesquisa (Hair, Babin, Money, \& Samouel, 2005).

\subsection{Eficiência Operacional}

O termo "eficiência" tem origem no latim efficientia, que significa "ato, ação, força, virtude de produzir um efeito" (Ferreira, 1975, s.p.).

Eficiência é a "virtude ou característica (que pode ser atribuída a uma pessoa, máquina, técnica ou empreendimento) de conseguir o melhor rendimento com o mínimo de erros, dispêndio de energia, tempo, dinheiro ou meios" (Houaiss, 2001, s.p.).

Processos operacionais produzem produtos e serviços por meio da transformação de entradas em saídas, esse evento é comumente chamado de processo de transformação (Slack, Chambers \& Johnston, 2009).

Cogan (1994) diferencia as empresas prestadoras de serviços das indústrias manufatureiras nos seguintes aspectos: (a) o serviço não é passível de ser estocado; (b) não poderá haver substituição em caso de "defeito", o que obriga a um processo de qualidade vigorando no momento da prestação do serviço; (c) capacidade de recursos e demanda de utilização, se não forem bem estimados, podem resultar na formação de filas de espera por atendimento; (d) é intangível, e (e) requer pessoas treinadas envolvidas em todas as etapas.

Não são raras as associações entre eficiência operacional e redução de custos, porém reduzir o termo a essa simples tarefa significa deixar de atentar para 
itens relevantes, como otimização de recursos, qualidade na entrega e melhoria de processos, sendo que esse último não se refere apenas à revisão da cadeia produtiva, como o emprego maciço da tecnologia.

De modo geral, pode-se relacionar eficiência à forma como os recursos são consumidos, mais especificamente, na quantidade de recurso empregada no processo produtivo até a entrega final do produto ou serviço ao cliente. É possível considerar eficiente uma empresa que utiliza bem os recursos na cadeia produtiva, produzindo em quantidade e qualidade produtos e serviços que atendam a necessidade do cliente (Torres Júnior, \& Miyake, 2011).

Esses mesmos autores esclarecem sobre as diferenças entre os termos eficiência e eficácia. Enquanto eficiência trata da melhor utilização dos recursos, a eficácia tem relação com os objetivos propostos, como a entrega de resultados aos clientes (Torres Júnior, \& Miyake, 2011). Toda organização almeja ser eficiente e eficaz na sua operação, e entende-se que esse é o maior desafio que os gestores podem enfrentar. É fundamental que se desenvolva internamente diretrizes adequadas para que a busca por desempenho considere esses critérios.

Porter (1996) ensina que eficiente é a empresa que exerce suas atividades de maneira igual ou superior aos seus rivais. Essas atividades incluem qualquer prática que as leve a utilizar seus recursos de maneira mais eficiente, reduzindo o volume de produtos defeituosos ou construindo um processo de produção que entregue produtos com melhor qualidade em menor tempo. Esse autor, cujo tema posicionamento estratégico é o foco de seus estudos, estabelece um paralelo entre eficiência e diferenciação de mercado, quando afirma que posicionamento estratégico é o exercício das atividades de modo diferente da concorrência, ou mesmo o exercício das mesmas atividades de forma diferenciada, tornando evidentes as diferenças de eficiência operacional entre os diversos players do mesmo segmento ou não de atuação.

Shingo (1996) propôs o Mecanismo da Função Produção (MFP), um instrumento de análise da função de produção que enxerga o sistema produtivo como uma rede de processos e operações, cujos recursos envolvidos (materiais, pessoas e 
equipamentos) sofrem intersecções, participando de uma mesma função em determinado tempo e espaço.

O desenho da cadeia produtiva é projetado para atender as necessidades competitivas da organização, de forma que processos e sistema produtivo estejam interligados e funcionando em cadeia, sistemicamente, e que cada etapa do ciclo afete de alguma forma o processo seguinte e, por essa razão, seu resultado conjunto determinará o desempenho geral do negócio (Antunes, \& Trevizan, 2000).

É notório que as instituições que prestam serviços de saúde enfrentam grandes desafios para aumento da produtividade. Alguns trabalhos apontam a necessidade de uma redefinição da rede de operações do setor e da adoção de novas práticas para a gestão de processos, privilegiando atividades que notadamente agreguem valor para os usuários finais (Christensen, Grossman, \& Hwang, 2009).

O assunto eficiência em serviços de saúde, inevitavelmente, passa pela discussão de aspectos de qualidade, uma vez que o erro pode gerar um dano à vida. O planejamento das entradas dos processos e o acompanhamento do atendimento é fator crítico de sucesso, sendo a contingência um aspecto obrigatório. O maior desafio está em ter um processo flexível o suficiente para atendimento das demandas adicionais de serviços não previstas e, muitas vezes, urgentes.

\subsection{Gestão por processos de negócios}

Processo é uma atividade ou um conjunto delas, que tem uma entrada, uma adição de valor e uma saída para um cliente específico, para tal transformação são utilizados os recursos da organização (Harrington, 1991). Na visão de Hammer e Champy (1994), essas atividades são realizadas em uma sequência lógica de ponta a ponta, visando produzir um bem ou serviço que tenha valor para o cliente, superando as fronteiras funcionais.

O BPM CBOK (2009) traz a seguinte definição: 
Gerenciamento de Processos de Negócio (BPM) é uma abordagem disciplinada para identificar, desenhar, executar, documentar, medir, monitorar, controlar e melhorar processos de negócio automatizados ou não, para alcançar os resultados pretendidos consistentes e alinhados com as metas estratégicas de uma organização. BPM envolve a definição deliberada, colaborativa e cada vez mais assistida por tecnologia, melhoria, inovação e gerenciamento de processos de negócio ponta a ponta que conduzem a resultados de negócios, criam valor e permitem que uma organização cumpra com seus objetivos de negócio com mais agilidade. BPM permite que uma organização alinhe seus processos de negócio à sua estratégia organizacional, conduzindo a um desempenho eficiente em toda a organização através de melhorias das atividades especificas de trabalho em um departamento, a organização como um todo ou entre organizações.

Já o termo gestão por processos se refere a um mecanismo de gestão apoiador das decisões estratégicas e operacionais de uma empresa. Na prática, refere-se ao mecanismo de melhoria contínua dos processos críticos, tendo como foco a necessidade dos clientes (Candido, Ferreira \& Zuhlke, 2008).

Ao buscar as diversas definições de gestão de processos de negócios, Paim, Cardoso, Caulliraux e Clemente (2009) relatam que há termos que se repetem: melhoria, inovação, engenharia, controle, documentação, otimização, implantação, modelagem, automação, continuidade, execução, análise e mensuração. No entanto, os autores entendem gestão por processos como a gestão organizacional com base nos seus processos.

De acordo com Debruin e Doebeli (2009), a gestão por processos pode ser dividida em três tipos distintos de abordagem: foco em tecnologia e sistemas de informação, foco na gestão e melhoria dos processos de negócio e foco na gestão organizacional por processo de negócio.

Nas estruturas organizacionais tradicionais, a divisão é feita por departamentos, áreas, funções e tarefas, que comumente se refletem nos organogramas. Segundo Gonçalves (2000, p. 11), a organização é "um conjunto de unidades funcionais verticais isoladas umas das outras, operando em paralelo, sem muita interligação. Nesse modelo, os processos precisam atravessar as fronteiras entre as 'chaminés' funcionais, com sensível perda de tempo, qualidade e capacidade de atendimento". A estruturação por processos é uma medida para evitar a 
abordagem das chaminés, em um modelo em que os processos cruzam fronteiras e estabelecem as conexões necessárias para a eficiência no atendimento.

\begin{tabular}{|l|l|}
\hline Abordagem de aplicação de BPM & Descrição \\
\hline Tecnologia e sistemas de informação & $\begin{array}{l}\text { Entende BPM como uma solução para } \\
\text { negócios, utilizando sistemas de software ou } \\
\text { tecnologias para automatizar e gerenciar os } \\
\text { processos de negócio. }\end{array}$ \\
\hline Gestão e melhorias de processos de negócio & $\begin{array}{l}\text { Entende BPM como uma abordagem para } \\
\text { gerenciar e melhorar os processos de negócio } \\
\text { com foco em seu ciclo de vida. }\end{array}$ \\
\hline $\begin{array}{l}\text { Gestão de organização por processos de } \\
\text { negócio }\end{array}$ & $\begin{array}{l}\text { Entende BPM como uma abordagem para } \\
\text { gerenciar uma organização por meio da visão } \\
\text { de processos de negócio (o foco vai além dos } \\
\text { processos de negócio). }\end{array}$ \\
\hline
\end{tabular}

Figura 3 Abordagem de aplicação de BPM (Business Process Management, em português, Gestão de Processo de Negócio).

Fonte: T. Debruin e G. Doebeli, 2009, BPM as an organizational approach: the experience of an Australian transport provider, p. 166.

Ainda segundo o mesmo autor, olhando especialmente para a empresa de serviços, cuja sequência de atividades nem sempre é clara e visível, nem pelos próprios executores, tampouco pelo cliente, o conceito de processos assume importância fundamental (Gonçalves, 2000).

Ao reorganizar a empresa a partir da perspectiva de processos de negócio, a principal alteração passa a ser o foco no cliente externo. Deve-se considerar que os processos começam e terminam no cliente, ou seja, partem do desejo dele, e terminam com a aquisição do que ele precisa. O cliente assume o centro, e o objetivo final passa a ser a oferta de mais valor, de forma mais rápida e a um custo mais baixo. Os executores dessa cadeia também assumem nova posição em uma gestão por processos, uma vez que devem assumir mais responsabilidade e desenvolver a capacidade de trabalho em equipe em ambientes de colaboração (Hammer, 1998). 
A fundamentação teórica da gestão por processos aponta para a premissa de que, para criação e manutenção de bons produtos e serviços, é fundamental que a visão de processos de ponta a ponta, a partir da perspectiva do cliente, seja um objetivo da organização e de sua estrutura de gestão (Jesus \& Macieira, 2015).

Na prática, a estrutura funcional comum, com pessoas que respondem as suas lideranças, de forma hierarquizada, não desaparecem na estrutura por processos. Conforme os 'process owners' (donos do processo) ganham intimidade com o projeto e assumem mais responsabilidade pela concepção e funcionamento dos processos críticos das empresas, os cargos mais altos se concentram mais na formação técnica e capacitação para a atuação nos diversos níveis da organização (Gonçalves, 2000).

Na saúde, a questão da humanização se faz presente como foco na entrega de valor aos clientes e usuários. Para Deslandes (2004), o processo de humanizar o atendimento passa obrigatoriamente pela revisão do processo de produção.

Gonçalves (2000) apresenta cinco estágios de estruturação de processos, começando de um patamar em que não se sabe do que se trata, até o patamar em que a empresa está totalmente estruturada por processos. 


\begin{tabular}{|c|c|c|c|c|c|}
\hline & \multicolumn{5}{|c|}{ Etapas } \\
\hline & A & B & C & D & $\mathrm{E}$ \\
\hline Onde estamos & $\begin{array}{l}\text { Processos, que } \\
\text { processos? }\end{array}$ & $\begin{array}{l}\text { Identificamos nossos } \\
\text { processos, subprocessos } \\
\text { e subsubprocessos }\end{array}$ & $\begin{array}{l}\text { Melhoramos os processos } \\
\text { essenciais }\end{array}$ & $\begin{array}{l}\text { Redistribuímos nossos } \\
\text { recursos ao longo de } \\
\text { nossos processos } \\
\text { essenciais e atribuímos a } \\
\text { responsabilidade a um } \\
\text { process owner }\end{array}$ & $\begin{array}{l}\text { Nossa organização foi } \\
\text { desenhada pela lógica } \\
\text { dos nossos processos } \\
\text { essenciais }\end{array}$ \\
\hline \multirow{4}{*}{ Comentários } & $\begin{array}{l}\text { As empresas sequer se } \\
\text { deram conta }\end{array}$ & $\begin{array}{l}\text { O foco do esforço ainda } \\
\text { está nas funções }\end{array}$ & $\begin{array}{l}\text { As empresas ainda } \\
\text { raciocinam por funções, } \\
\text { mesmo que conheçam } \\
\text { bem seus processos }\end{array}$ & $\begin{array}{l}\text { Ainda é um remendo, } \\
\text { construído sobre uma } \\
\text { estrutura antiquada }\end{array}$ & $\begin{array}{l}\text { É a forma de organização } \\
\text { indicada para a gestão } \\
\text { por processo }\end{array}$ \\
\hline & $\begin{array}{l}\text { Em geral, as empresas } \\
\text { percebem a penas os } \\
\text { processos de manufatura, } \\
\text { os outros processos são } \\
\text { acessórios }\end{array}$ & $\begin{array}{l}\text { Os processos são } \\
\text { enquadrados na estrutura } \\
\text { funcional }\end{array}$ & $\begin{array}{l}\text { O uso de case managers } \\
\text { pode mel horar o contato } \\
\text { com o cliente }\end{array}$ & $\begin{array}{l}\text { As empresas começam a } \\
\text { obter resultados da } \\
\text { ênfase em processos, mas } \\
\text { com um alto desconforto } \\
\text { na organização }\end{array}$ & $\begin{array}{l}\text { Áreas funcionais } \\
\text { praticamente não existem }\end{array}$ \\
\hline & & $\begin{array}{l}\text { A abordagem é ampla } \\
\text { demais }\end{array}$ & $\begin{array}{l}\text { O poder ainda reside nas } \\
\text { unidades verticais }\end{array}$ & $\begin{array}{l}\text { Implantação na nova } \\
\text { organização }\end{array}$ & $\begin{array}{l}\text { As metas e métricas são } \\
\text { definidas para os } \\
\text { processos }\end{array}$ \\
\hline & & $\begin{array}{l}\text { A forma de trabalho é } \\
\text { provavel mente ainda } \\
\text { antiga }\end{array}$ & & & \\
\hline $\begin{array}{l}\text { Até onde dá } \\
\text { para irmos em } \\
\text { termos de } \\
\text { negócio }\end{array}$ & $\begin{array}{l}\text { Enquanto o assunto é } \\
\text { pura manufatura, as } \\
\text { chances de } \\
\text { aperfeiçoamento radical } \\
\text { são limitadas }\end{array}$ & $\begin{array}{l}\text { Aperfeiçoamento de } \\
\text { gargalos e obtenção de } \\
\text { melhoras de eficiência } \\
\text { pontuais }\end{array}$ & \begin{tabular}{|l|} 
Aperfeiçoamento dos \\
processos essenciais, \\
cortando as atividades e \\
funções que não agregam \\
valor
\end{tabular} & $\begin{array}{l}\text { Gestão de alguns } \\
\text { processos isolados e } \\
\text { integração com processos } \\
\text { auxiliares }\end{array}$ & $\begin{array}{l}\text { Gestão integrada dos } \\
\text { processos essenciais }\end{array}$ \\
\hline
\end{tabular}

Figura 4. Estágios de estruturação de processos.

Fonte: J. E. L. Gonçalves, 2000, Processo, que processo?, p. 14.

Esse mesmo autor também apresenta o que deve ser analisado, estruturado e implementado em cada um dos estágios para que se atinja novos patamares, rumo à gestão por processos (Gonçalves, 2000). 


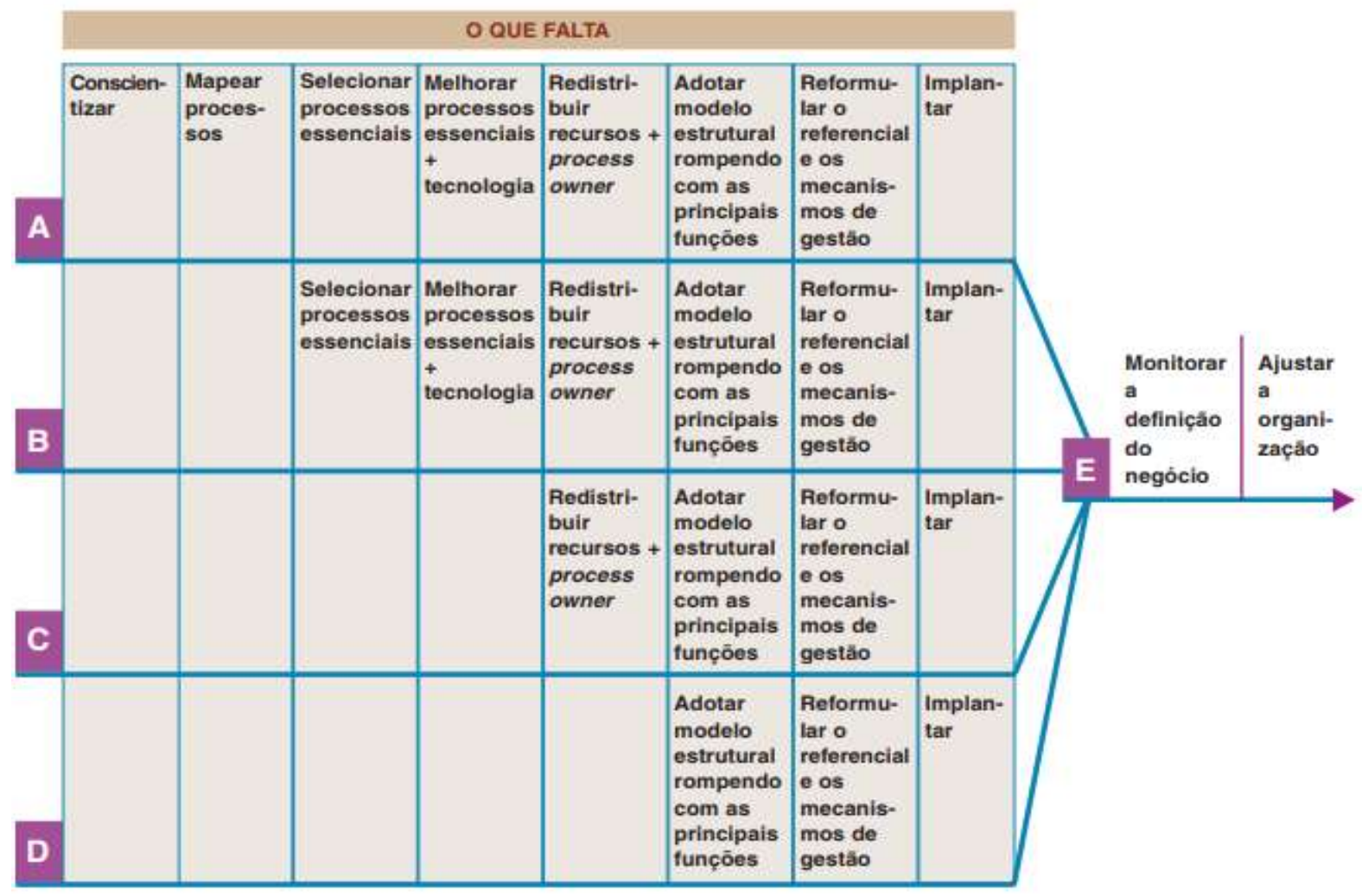

Figura 5. O que falta em cada estágio para uma gestão baseada em processos. Fonte: J. E. L. Gonçalves, 2000, Processo, que processo?, p. 16.

Para Paim et al. (2009), quando se fala de organizações produtivas de qualquer espécie, há que se considerar a coordenação do trabalho realizado, que nada mais é do que a forma com que as pessoas e suas atividades são dispostas, como se faz a gestão desses recursos no dia a dia de trabalho e como se analisam os resultados de forma a identificar oportunidades e implantar modificações que promovam melhorias nas operações. Nesse prisma, a necessidade da gestão por processos se faz presente, uma vez que a necessidade de coordenar deriva da própria ação de dividir e organizar o trabalho em si, superando as limitações dos modelos atuais de organização do trabalho.

Para Jesus e Macieira (2015), pode-se listar quatro desafios das empresas que queiram realmente oferecer melhores produtos e serviços, com aumento de valor para seus clientes, à partir da implantação da teoria de gestão por processos: 1) implantar projetos que transformem a produção, melhorando a oferta ao cliente; 2) 
sustentar, por meio da gestão do dia a dia, o valor criado aos clientes; 3) os processos provém da estratégia, e portanto estão interligados, e 4) tecnologia que apoie todos os processos.

A ABPMP (2013) enfatiza que, ainda que seja possível encontrar inúmeros modelos que apoiem a análise de todas as etapas do processo de negócio, que variam no volume e detalhamento das fases, a maioria deles utiliza o ciclo básico de PDCA (Plan, Do, Check, Act) de Deming.

Os sistemas de informação permitem aos gestores dos serviços de saúde o alinhamento da execução com as decisões estratégicas dos serviços, além da possibilidade de acompanhar o dia a dia de trabalho e realizar auditorias. (Vidor, Fischer e Bordin, 2011)

Considera-se interoperabilidade a comunicação entre os diversos sistemas de informação, permitindo fluxo de dados e informações no suporte à tomada de decisão. Sua ausência pode levar à ineficiência na utilização dos recursos, bem como a condutas inadequadas por parte da equipe de atendimento. A interoperabilidade é um caminho que as instituições devem perseguir, garantindo o acesso de toda a equipe de profissionais de saúde às informações necessárias para decisões que preservem a segurança do usuário dos serviços (Orlova et al., 2005).

Do ponto de vista do usuário de saúde, a interoperabilidade permite um cuidado coordenado, ou seja, baseado em informações internas e externas, permitindo um cuidado contínuo, menos invasivo e com melhor custo-beneficio (Enthoven, 2008).

\subsection{Gestão Organizacional}

\subsubsection{Estrutura Organizacional}


A estrutura organizacional estabelece a forma como as atividades são executadas, isto é, como as pessoas se relacionam hierarquicamente e como se controlam os produtos dessas interações (Robbins, 1990).

Tushman e Nadler (1997) sugerem a criação de comitês e equipes de trabalho com indivíduos de áreas distintas, buscando a resolução de problemas comuns como estratégia para integração. Proporcionar ambientes de discussão e troca de informações melhora a comunicação e acelera a adaptação.

A implementação da gestão por processos pode encontrar grandes resistências internas. Isso porque um dos principais indicadores de desempenho passa a ser a satisfação do cliente, o que torna tanto equipe, quanto o corpo gerencial, mais viabilizadores da necessidade do cliente, do que grandes tomadores de decisão. (Maximiano, 2004).

Ostroff, em seu livro publicado em 1999, aborda a gestão horizontalizada e como utilizá-la na transformação de uma organização. Ele sugere que:

- A análise deve partir de processos que atravessem a organização, e não de atividades isoladas;

- Cada processo deve ter um "dono", e essa responsabilidade não necessariamente tem relação com posição hierárquica, mas com a contribuição do indivíduo na entrega;

- Redução da hierarquia e tarefas que não agreguem valor ao processo;

- Capacitar e empoderar a equipe para resolver problemas;

- Usar a tecnologia para permitir respostas rápidas;

- Medir resultado continuamente e,

- Promover uma cultura organizacional de cooperação e colaboração.

Considera-se supervisão uma atividade ou um conjunto de atividades com o objetivo de garantir a adequada execução do trabalho e a obtenção dos resultados planejados. Essas atividades são realizadas por indivíduos com competências complementares à da equipe de execução, responsáveis por oferecer apoio gerencial e técnico, além influenciar no rumo do trabalho (Campos, 2007). 
Quando se analisa o conceito de integração em saúde, verifica-se que a ação prevê a manutenção de uma governança (ou supervisão) comum entre diversos atores ou organizações autônomas, orquestrando a interdependência entre elas, com o objetivo de entregar um projeto de atendimento clínico coletivo, assegurando a continuidade dos serviços, organizados no tempo e no espaço, utilizando os conhecimentos disponíveis na equipe multidisciplinar (Hartz \& Contandriopoulos, 2004).

\subsubsection{Competências}

Segundo Bergue (2014), a administração dos recursos humanos precisa acompanhar o aumento do grau de complexidade das organizações, por meio de modelos de gestão que enderecem as principais deficiências, apoiando o sucesso das áreas funcionais.

Nesse contexto, definir as competências mínimas necessárias para cada uma das posições e confrontá-las com os candidatos no momento do recrutamento e seleção de pessoal se torna ação indispensável na estratégia de gestão de pessoas. Dessa forma, a adequada alocação desse trabalhador trará um resultado mais rápido para a área de negócio, além de contribuir com adequados índices de retenção e desempenho (Monteiro, 2010).

Essa estratégia da administração de pessoal também considera a forma como o trabalhador é visto e tratado. A estratégia de controle, em que cada indivíduo é um número e um centro de custo, já demonstrou sua ineficiência. Já na estratégia de comprometimento, o indivíduo é tratado como um colaborador na entrega do resultado e, portanto, é razoável que a empresa invista para que ele produza cada vez melhor. Essa estratégia se fundamenta no pressuposto de que, quanto maior o comprometimento, maior o desempenho das organizações (Albuquerque, 2002). 


\section{Método de Pesquisa}

\subsection{Contexto}

Este capítulo tem por objetivo apresentar o método utilizado para o desenvolvimento desta pesquisa, classificando-o quanto ao propósito e abordagem.

A metodologia pode ser vista como conhecimento geral e seu domínio está entre habilidades necessárias ao pesquisador para se orientar no processo de investigação, tomar as melhores decisões, se apropriar de conceitos, levantar hipóteses, escolher técnicas e selecionar os dados adequados (Thiollent, 2011).

Segundo Walliman (2015), os projetos de pesquisa servem para explicar um fenômeno ou testar uma teoria. Os métodos de pesquisa são parte dos projetos de pesquisa e pretendem explicitar as técnicas utilizadas para construção desse trabalho.

\subsection{Abordagem da pesquisa}

O estudo quantitativo é estabelecido por hipóteses claramente especificadas e variáveis operacionalmente definidas, sendo notória a preocupação com a objetividade dos dados, e sua quantificação, como base para o estabelecimento dos resultados. Precisão é uma característica forte, havendo espaço apenas para uma pequena margem de segurança em relação às inferências obtidas. Em comparação com a pesquisa qualitativa, percebe-se que os pontos fortes de um estudo quantitativo não são típicos da pesquisa qualitativa, cujos dados são geralmente coletados por técnicas que exigem interpretação subjetiva (Godoy, 1995).

A pesquisa qualitativa tem como principal característica estabelecer um processo investigativo por meio do olhar de um observador. Ela consiste em um conjunto de interpretações capazes de tornar visível o objeto investigado. Nesse contexto, esse tipo de pesquisa permite que o pesquisador estude o fenômeno em 
seu contexto natural (abordagem naturalística) e, a partir desse estudo, busque compreender os fenômenos, através do sentido que as pessoas atribuem eles (Flick, 2009).

O ponto central dos estudos qualitativos é explorar o problema de pesquisa, por meio da busca das evidências, com o objetivo de interpretar os achados e analisálos (Creswell, 2010). Contudo, ainda que não tenha apenas essa finalidade, esse tipo de pesquisa é muito praticado em estudos de avaliação de características do ambiente organizacional.

Este estudo é de abordagem qualitativa, pela ausência na precisão dos dados, bem como pela ausência da análise estatística. Pretende-se, ao longo da jornada da pesquisa, através do olhar e ação da pesquisadora sobre o problema pesquisado, levantar material suficiente e consistente e, por meio de interpretação e análise, responder à pergunta de pesquisa, tendo- se em vista seu foco amplo e sua delimitação prevista ao longo do estudo.

Reconhecendo a diversidade existentes nas pesquisas qualitativas Godoy (1995) apresenta alguns aspectos essenciais em estudos deste tipo:

A pesquisa qualitativa tem o ambiente natural como fonte direta de dados e o pesquisador como instrumento fundamental: abordagem na qual valoriza-se o contato direto e prolongado do pesquisador com o ambiente que está sendo estudado.

A pesquisa qualitativa é descritiva: os dados coletados aparecem sob a forma de transcrições de entrevistas, anotações de campo, fotografias, desenhos e vários tipos de documentos.

A abordagem qualitativa pode ser de caráter documental, etnográfica ou estudo de caso. Constitui-se um estudo de caso a análise detalhada e aprofundada de uma unidade de estudo. No entendimento de Godoy (1995), o estudo de caso detalha um ambiente, sujeito ou uma situação em particular. Esse método tem ganhado espaço nas pesquisas de administração, especialmente quando se procura entender a motivação e ocorrência de determinados fenômenos ou mesmo na análise de eventos que só fazem sentido quando analisados em determinado contexto. 
O levantamento de dados para este estudo dar-se-á em uma empresa privada de prestação de serviços em saúde. A partir da coleta e da análise de informações operacionais e gerenciais, relatórios de consultoria e dos dados dos sistemas de informação, pretende-se desenhar o cenário do negócio no início, implementar ações de mudança e, no fim da pesquisa, elucidar os impactos resultantes das mudanças implementadas.

Este estudo de caso utiliza a metodologia de pesquisa-ação, uma das formas de investigação-ação, a qual é definida por Tripp (2005), como toda tentativa continuada, sistemática e empiricamente fundamentada de aprimorar a prática. Ao mesmo tempo que realiza um diagnóstico e a análise de uma determinada situação (caso) ou produto, propõe mudanças que levem a um aprimoramento das práticas e produtos analisados. É um processo no qual se aprimora a prática pela alternância sistemática entre agir e investigar a respeito dela. Desta forma, planeja-se, implementa-se, descreve-se e avalia-se uma mudança, aprendendo-se no decorrer do processo, tanto a respeito da prática quanto da própria investigação. A pesquisaação requer ação tanto nas áreas da prática quanto da pesquisa, de modo que, em maior ou menor medida, terá características tanto da prática rotineira quanto da pesquisa científica (Tripp, 2005).

\subsection{Pesquisa Ação}

São várias as definições de pesquisa-ação. Segundo Thiollent (2011), a pesquisa-ação pode ser considerada uma forma de pesquisa social, realizada com o objetivo de resolver um problema coletivo, com base empírica, em que os pesquisadores atuam de forma participativa com outros participantes envolvidos no ambiente da pesquisa.

Tripp (2005) define pesquisa-ação como uma investigação na forma de ação, cuja base parte de técnicas que dão foco às ações, objetivando a melhoria da prática.

A pesquisa-ação nasceu da necessidade de aproximar a prática da teria, de forma que a prática possa ser inovada tendo como base o próprio processo de 
pesquisa, e não apenas como consequência do que a etapa final do projeto recomenda (Engel, 2000).

Considera-se parte integrante do processo da pesquisa-ação a produção de conhecimentos, o ganho de experiência, maior repertório para discussão ou avanço no debate sobre determinado tema, sendo indiscutível a sua associação entre prática e teoria (Thiollent, 2011).

Para Thiollent (2007), a pesquisa-ação consiste na execução de pesquisa e de ação em um único processo, no qual existe uma interação explícita entre o investigador e os participantes implicados, buscando interativamente compreender os problemas coletivos e experimentar soluções na situação observada. Coughlan e Coughlan (2002) apresentam um conjunto de premissas e condições que caracterizam a pesquisa-ação:

- O pesquisador toma ação e não é um mero observador;

- Envolve sempre dois objetivos: solucionar um problema e contribuir para a ciência;

- É interativa (cooperação e interatividade entre os envolvidos);

- Objetiva desenvolver um entendimento holístico;

- É fundamentalmente relacionada à mudança;

- Pode incluir diferentes métodos de coleta de dados;

- Deve ser conduzida em tempo real;

- Requer critérios próprios de qualidade para sua avaliação.

Mello, Turrioni, Xavier e Campos (2012) elaboraram uma proposta de conteúdo e sequência que ilustra a condução de uma pesquisa-ação, conforme demonstra a Figura 6. 


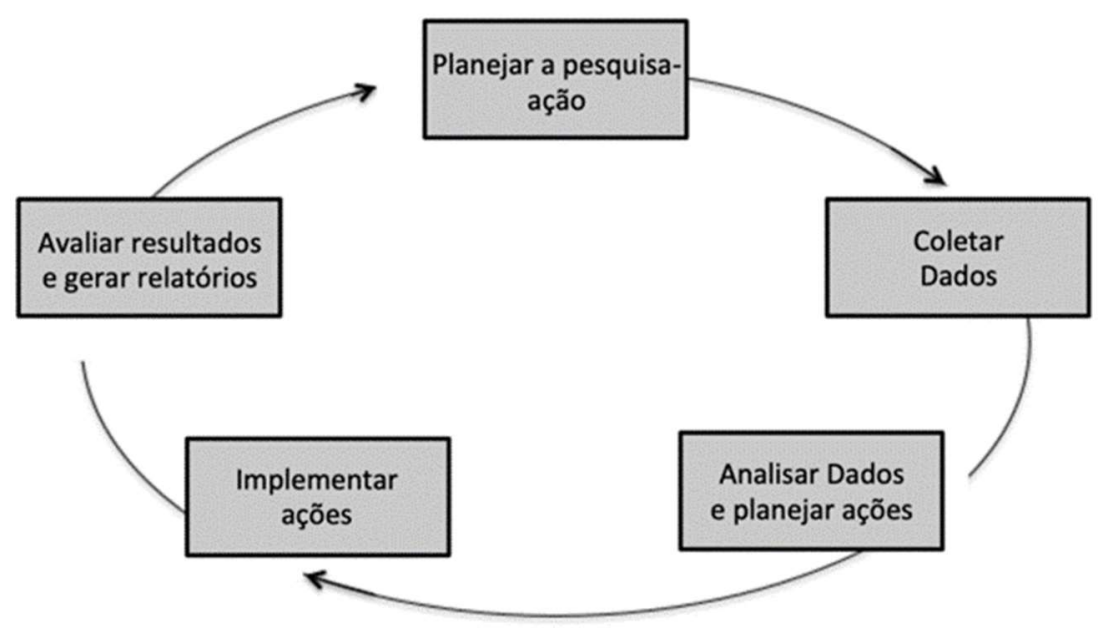

Figura 6. Estrutura para condução de pesquisa-ação.

Fonte: Mello, Turrioni, Xavier e Campos (2012). Adaptado de Westbrook (1995), Coughlan e Coughlan (2002) e Thiollent (2007).

Com base nesses conceitos da pesquisa-ação, as etapas e atividades conduzidas para atingir os objetivos propostos nesta pesquisa, em sintonia com o problema apresentado, são:

1. Planejar a pesquisa-ação
a. Definição do contexto e do objetivo da pesquisa
b. Definição da estrutura conceitual teórica
c. Seleção da unidade de análise
d. Definição de técnicas para coleta de dados

2. Coletar dados

a. Coleta de dados primários
i. Observações
ii. Levantamentos

b. Coleta de dados secundários

i. Coleta de documentos

ii. Identificação dos locais do ambiente da unidade de análise

3. Analisar dados e planejar ações

a. Analisar dados coletados

b. Elaborar plano de ações

4. Implementar ações 
a. Execução das ações

b. Coleta de resultados

5. Avaliar resultados

a. Avaliação dos resultados das ações implementadas

b. Implicações teóricas e práticas dos resultados obtidos

6. Gerar relatório

a. Elaboração de conclusões

b. Limitações das conclusões

C. Recomendações para continuidade de ações

d. Recomendações para estudos futuros

Segundo Mello, Turrioni, Xavier e Campos (2012), na pesquisa-ação, a fundamentação teórica identifica as lacunas nas quais podem existir problemas a serem solucionados em comunhão com o contexto organizacional que promove a pesquisa participativa.

Yin (2005) considera que a definição da unidade de análise está relacionada com a maneira como as questões iniciais de pesquisa foram definidas.

Uma vez que a abordagem de pesquisa-ação deste estudo teve sua iniciação motivada pelo problema de redesenho da operação do negócio, objetivando ganho de eficiência, a unidade de análise foi definida como sendo a central de atendimento ao usuário. 


\section{Planejamento da pesquisa}

\subsection{Entendimento do problema}

O grupo de empresas objeto deste trabalho, que será chamado apenas de empresa, foi fundado em 1979 e iniciou suas atividades de prestação de serviços em saúde atuando no transporte terrestre de usuários. Ao longo de seus 40 anos de existência, a empresa se desenvolveu, ampliando o leque de oferta de serviços, passando a atuar na modalidade de internação domiciliar e gerenciamento de doentes crônicos. Suas atividades podem ser enquadradas, com relação à prestação de serviços em saúde, nas atenções primária (com gerenciamento de doentes crônicos), secundária (com transporte terrestre de usuários e atendimento de urgência) e terciária (com a assistência domiciliar).

Em paralelo ao crescimento da empresa, o mercado de saúde também se transformou. Os custos cresceram, e os agentes intermediadores financeiros buscavam alternativas para melhorar a eficiência de sua operação, de forma que as margens de lucro fossem preservadas ou ampliadas. Nesse contexto, o aspecto qualidade, característica marcante na prestação de serviços dessa companhia, deixou de ser o valor prioritário e passou a competir com o aspecto resultado, envolvendo especialmente o custo dos serviços prestados. A alternativa para continuar prestando um serviço com qualidade com um custo menor seria atuar na redução do desperdício por meio da melhoria contínua. Isso requereria mudanças no modelo de cultura e gestão da companhia, com a instituição de indicadores de desempenho, além de investimento em tecnologia para suportar as melhorias de processos definidas a partir da análise dos resultados entregues.

O mercado também passou a valorizar iniciativas que propunham a integralidade do cuidado, minimizando a atuação fragmentada do sistema e oferecendo ao usuário um atendimento mais coordenado. O desperdício de recursos passou a ser fonte de preocupação, e a gestão de acesso ao sistema de saúde surgiu como alternativa para conter esse desperdício. Segundo Christensen et al., (2009), 
em um sistema integrado, há maior interesse em manter os usuários do sistema saudáveis e, na eventual necessidade de um tratamento, encaminhá-los a uma estrutura cujo modelo de gestão se proponha a realizar a tarefa da maneira mais eficaz e econômica possível.

Esse modelo de atuação pouco integrado do ponto de vista do atendimento ao usuário, somado a não adaptação da estrutura da empresa à exigência de custo imposta pelo mercado, levou a companhia a perder contratos e receitas. Diante disso, a crise financeira obrigou a organização a rever seu modelo de atuação e de governança. Os indicadores que mais evidenciam essa crise foram os de faturamento. Em quatro anos (2015 - 2018), houve perda de receita e diminuição de 12,1 pontos percentuais no lucro bruto.

Como parte do plano de recuperação financeira, uma consultoria foi contratada para realizar um diagnóstico e um plano de recuperação. Após três meses de trabalho, os proprietários optaram por contratar essa mesma equipe de consultores para executar o plano, realizando os ajustes necessários para estancar a perda financeira e melhorar os processos produtivos. A atuação da consultoria se deu nos processos internos e não abrangeu análise dos produtos e do mercado.

No mês de outubro de 2017, foi aplicada uma pesquisa junto aos clientes, cujo objetivo foi avaliar a repercussão da crise financeira na imagem da empresa. Os principais problemas apontados nessa pesquisa integrariam o diagnóstico e o plano de recuperação da empresa.

Essa pesquisa se fundamentou na metodologia do Net Promoter Score (NPS), comumente usada pelas principais empresas do mundo para mapear a experiência do cliente. Ela avalia a satisfação através de uma escala entre 0 e 10 pontos, em respostas à pergunta: "qual é a probabilidade de você recomendar a empresa em questão para um amigo ou colega?

Esse escore é baseado na perspectiva fundamental de que toda a empresa tem clientes que podem ser divididos em três categorias: os promotores (entusiastas que comprariam seus produtos e os recomendariam aos seus clientes), os passivos (que estão satisfeitos, porém neutros em relação à repercussões da imagem da 
empresa) e os detratores (que são clientes insatisfeitos e com relacionamento ruim e que, portanto, contraindicariam a marca para seus conhecidos). (Koladycz, R. Fernandez,G., Gray, K., Marriott, H, 2018).

A amostra continha 91 empresas clientes, sendo que, dessas, 49 responderam, o que correspondeu a $53,8 \%$ de retorno.

Em uma análise geral dos resultados da pesquisa, a principal constatação foi a de que os serviços prestados eram considerados bons, que haveria recomendação dos serviços para outros potenciais clientes. Contudo, o preço praticado estava tornando a operação inviável, pois os clientes estavam enfrentando dificuldades para encaixar as tarifas cobradas dentro das suas tabelas de preço praticadas com o mercado.

De acordo com a cadeia de valor da saúde (Figura 1), os clientes dessa empresa são intermediadores financeiros do sistema, responsáveis pelo acesso dos usuários às instituições de saúde. Sua principal medida de sustentabilidade financeira é a taxa de sinistralidade, que basicamente consiste na relação entre a receita e as despesas. Segundo informações divulgadas pela sala de situação da ANS, no $3^{\circ}$ trimestre de 2018, o índice de sinistralidade apurado era de $84 \%$. Essa medida tem um grande impacto nas relações existentes entre os intermediadores financeiros e os prestadores de serviço em saúde. Considerando que o preço do serviço prestado reflete diretamente nas taxas de sinistralidade, aqueles que praticam valores acima da média do mercado podem ter dificuldades em firmarem contratos com as operadoras de planos de saúde (ANS, 2018). 


\begin{tabular}{|lrr|}
\hline \multicolumn{3}{c|}{ Receita/Despesa no Ano } \\
\hline & $3^{\circ} \mathrm{Tri} / 2017$ & $3^{\circ} \mathrm{Tri} / 2018$ \\
\hline Receita de contraprestações & 129.826 .936 .818 & 142.905 .247 .633 \\
Outras receitas operacionais & 12.256 .198 .900 & 12.697 .023 .742 \\
Despesa assistencial & 110.446 .620 .227 & 120.057 .720 .892 \\
Despesa administrativa & 13.464 .532 .999 & 14.083 .622 .168 \\
Despesa comercialização & 3.775 .058 .368 & 4.055 .522 .669 \\
Outras despesas operacionais & 12.602 .579 .220 & 13.720 .852 .288 \\
Taxa de sinistralidade & $85.1 \%$ & $84 . \%$ \\
\hline
\end{tabular}

Figura 7. Taxa de sinistralidade das operadoras de planos de saúde no Brasil.

Fonte: http://www.ans.gov.br/perfil-do-setor/dados-e-indicadores-do-setor/sala-de-situacao, visualizado em 01/05/2019.

A conclusão foi a de que os processos operacionais essenciais precisavam sofrer mudanças, de forma que a mão de obra e os insumos fossem utilizados em sua máxima potencialidade, diminuindo os custos e aumentando o valor para o cliente e, consequentemente, para usuário.

A Figura 8 resume o formato de atuação da empresa de saúde extra-hospitalar objeto deste trabalho. A partir de uma questão de saúde demandada, o serviço é ativado. Cabe ressaltar que o intermediador financeiro é o elo entre o usuário e a empresa que presta serviços.

Considera-se atendimento extra hospitalar toda a assistência à saúde prestada no ambiente externo ao hospital, para usuários de diversas complexidades clínicas.

Para que haja uma definição adequada do tratamento e o atendimento possa ser executado, faz-se necessário dispor de uma equipe treinada, que seja direcionada por meio de protocolos assistenciais, que tenha à sua disposição os métodos diagnósticos necessários para definir a conduta clínica a ser tomada com o usuário. Insumos materiais, medicamentos, equipamentos e mobiliário também são elementos que devem ser considerados, para que uma adequada assistência seja prestada.

A união desses elementos prevê o atendimento da demanda de saúde apresentada. 


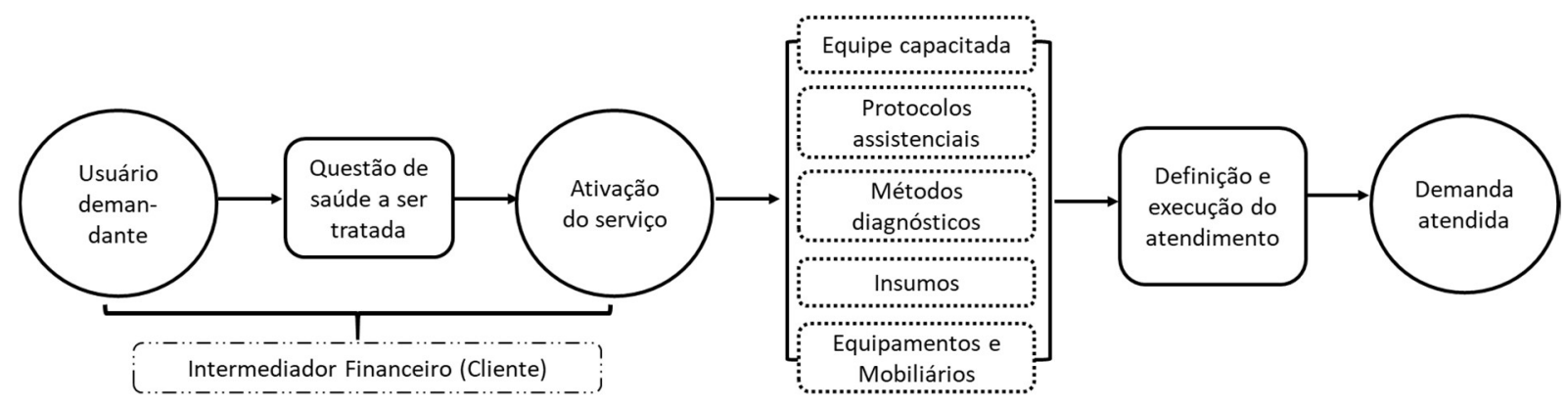

Figura 8. Acolhimento em saúde extra-hospitalar.

Fonte: elaborada pela autora.

\subsection{Planejamento das ações}

Para alcançar os objetivos propostos, foram planejadas as seguintes ações a serem executadas:

> Análise dos processos operacionais de atendimento: coleta de dados de todas as operações que recebem chamadas de usuário.

$>$ Proposta de novo processo de atendimento ao usuário: desenho do novo formato de recepção de demandas.

Análise dos atendimentos realizados: coleta de dados sobre a característica das chamadas, volumes e equipes de atendimento.

> Implementação da nova central de atendimento:

○ Implementação de novo sistema de telefonia: plataforma capaz de captar, distribuir e gravar as chamadas recebidas,

- Revisão dos sistemas de informação: adequações necessárias para atendimento das demandas dentro dos prazos estabelecidos com o usuário,

○ Revisão de procedimentos de trabalho: adequação ao novo desenho proposto,

○ Reestruturação da equipe de atendimento: redistribuição das pessoas, com base no cargo, formação e demanda,

- Revisão de atividades das equipes de atendimento: readequação das atividades administrativas e técnicas e 
- Revisão da estrutura organizacional: readequação da estrutura de pessoas para acomodar as características e volume da demanda. 


\section{Coleta de Dados}

\subsection{Diagnóstico da Consultoria}

Em janeiro de 2017, foi entregue aos sócios da empresa um relatório de diagnóstico, contendo os seguintes itens:

- Apresentação do diagnóstico: utilizada para validação do diagnóstico e validação do plano de implantação;

- Perfil de maturidade de processos: análise do perfil de maturidade dos processos;

- Análise de interfaces: material com a análise de interfaces dos processos;

- Simulador de resultado e caixa: planilha com as projeções de resultado e caixa esperados com a implantação do plano proposto.

A consultoria seguiu a metodologia diagnóstica ilustrada na Figura abaixo:

\begin{tabular}{ll|l|}
\hline Processos & Sistemas e Informações \\
- Análises de gap dos macroprocessos & $\begin{array}{l}\text { Perfil de maturidade dos processos } \\
\text { - Análise da base de dados e sistemas } \\
\text { de informação } \\
\text { Análise de informações operacionais, } \\
\text { gerenciais e estratégicas }\end{array}$ \\
\hline
\end{tabular}

Figura 9. Metodologia de desenvolvimento do diagnóstico. Fonte: Relatório da Consultoria.

Foram analisados os processos essenciais da empresa, com o objetivo de mapear as principais lacunas que impactavam os resultados do negócio. Além disso, esses processos foram classificados por perfis de maturidade, de forma que os 
esforços para a sua reestruturação e melhoria pudessem ser medidos. Passada essa etapa, foram analisados os sistemas de informação da empresa, de forma que fosse possível entender se eles refletiam os processos essenciais e se apoiavam os controles e indicadores do negócio. Considerando que prestadoras de serviços necessitam de um capital humano preparado e habilitado para atuar nos seus diferentes segmentos, o diagnóstico também abrangeu a análise do organograma, das principais lideranças, da equipe de especialistas e head count.

A conclusão do trabalho da consultoria foi de que a empresa tinha um faturamento interessante, mas sua geração de caixa não estava sendo suficiente, tendo alguma disponibilidade para investimento somente a partir de 2020, considerando a implementação de todas as mudanças sugeridas. O maior desafio seria sanear o saldo de caixa nos dois primeiros anos, devido ao acúmulo de financiamentos de curto prazo. Foi proposta uma série de ações que permitiria que o nível de endividamento (EBITDA) e a geração caixa a atingissem os patamares desejados em 24 meses. Segundo o relatório da consultoria, essas ações deveriam ser suportadas por uma extensa melhoria de processos e melhoria dos sistemas de informação em vigor na ocasião. Foram evidenciados:

- Desperdício de recursos (exemplo: uma farmácia era o maior fornecedor da empresa, sendo que existiam fornecedores de medicamentos que vendiam os mesmos produtos por valores inferiores ao balcão, além do prazo de faturamento);

- Desperdícios na utilização de recursos (exemplo: toda a equipe multidisciplinar poderia, a qualquer momento, acionar um motorista para cumprir sua rota de visitas aos domicílios);

- Não foram identificados responsáveis pelo controle da lucratividade dos contratos, apesar desse indicador ser passível de medição e acompanhamento. O resultado dessa falta de controle resultou na não aplicação do reajuste anual previsto em mais de $80 \%$ dos contratos da empresa e, consequente, na perda de margem de lucratividade.

Segundo o relatório da consultoria, analisando a estrutura de gestão:

- Existiam poucos processos e rotinas estabelecidas; 
- Existiam poucos indicadores de desempenho;

- Havia ausência de meritocracia;

- Havia ausência de informações críticas (exemplo: custeio);

- Havia dois sistemas de informação não integrados, cujos números não coincidiam;

A consultoria associou os problemas anteriores de processos e resultados à necessidade de desenvolvimento de uma cultura vencedora. A conclusão foi de que as pessoas, em grande parte:

- Tinham pouca segurança para tomar decisões;

- Eram burocráticas. Queriam fazer, mas não faziam;

- Estavam num ambiente de pouca colaboração, com muitas queixas em relação aos outros departamentos;

- Tinham muito foco no relacionamento, postura paternalista de defender parte da equipe, sem nenhuma medida de resultado atrelada;

- Tomavam decisões subjetivas baseadas no feeling e não em fatos e indicadores de desempenho;

- Tinham pouca ou nenhuma postura para desafiar a situação atual respostas de que "sempre foi assim" eram frequentes;

- Tinham falta de senso de urgência;

- Apresentavam pouca proatividade e envolvimento com os resultados da empresa;

- Não contavam com processos estruturados para apoiá-las na integração das operações e tomadas de decisão, situação essa que demandava a contratação de profissionais no perfil seniores, mais experientes e capacitados tecnicamente, e, consequentemente com maior custo e risco para o negócio, uma vez que a informação está sob o seu domínio e na eventual saída deles, o conhecimento seria perdido.

A atuação sobre a melhoria dos processos por si só levaria a uma cultura vencedora, solucionando boa parte dos problemas identificados, uma vez que:

- Os processos operacionais e administrativos seriam integrados, eliminando-se os conflitos atuais; 
- As decisões seriam mais assertivas e tomadas por quem, no processo, deve tomá-las;

- As atividades dos processos revisados seriam mais eficientes e determinariam quem seria o executor e como a atividade deveria ser feita;

- Seriam mapeadas as redes de colaboração e, a partir daí, se daria a determinação de atividades que eram diretamente dependentes de seus executores, ou seja, quem depende de quem;

- Nessa configuração, o resultado do processo passa a ser medido como um todo, com todos os elementos envolvidos;

- Haveria redução do paternalismo e aumento da meritocracia, pois o foco passaria a ser nos indicadores de desempenho dos processos;

- O desafio passaria a ser o alcance das metas e a manutenção dos índices de desempenho dos processos.

A consultoria permaneceu atuante por um período de 12 meses. Entretanto, a baixa performance relacionada à área financeira determinou sua saída. A governança passou a ser feita por um Comitê Executivo constituído pelos sócios e cinco diretores.

\section{Implementação das ações}

\subsection{Análise dos processos operacionais de atendimento}

Antes de analisar os processos operacionais, faz-se necessário contextualizar os principais agentes envolvidos e como estão sendo nomeados no contexto a seguir.

Será entendida como usuária toda pessoa que se beneficie dos serviços prestados pela empresa, podendo ser o próprio paciente ou seus familiares.

Será entendido como cliente toda a cadeia que custeia a prestação de serviços, podendo ser plano de saúde, empresas ou pessoas físicas. 
Serão entendidos como profissionais todos os envolvidos nos cuidados ao usuário final, podendo ser internos (ou seja, contratações diretas da empresa que presta o serviço), ou externos (quando estão vinculados à família ou ao cliente, mas atuam de forma integrada com a equipe de profissionais internos).

A definição e a execução do atendimento foram divididas em processos: transporte terrestre, internação domiciliar e gerenciamento de doentes crônicos. A melhora dos processos de atendimento nessas três modalidades levará à melhoria dos resultados e do desempenho da empresa.

\subsubsection{Transporte terrestre de usuários}

O transporte terrestre, também conhecido como Atendimento Pré-Hospitalar $(\mathrm{APH})$, está enquadrado na categoria de atendimento de urgência na atenção secundária. Esse serviço engloba todo atendimento que ocorre antes da chegada do usuário ao hospital, objetivando evitar danos, diminuindo taxas de morbidade e mortalidade. Esse atendimento prevê uma assistência de qualidade, com a maior brevidade possível, com equipe qualificada, de forma que o usuário chegue ao hospital com vida e com o mínimo de complicações possível. O APH pode ser de suporte básico à vida, composto por equipe técnica de baixa especialização e, por essa razão, sem autonomia para atuação através de manobras invasivas, bem como de suporte avançado à vida, com equipe composta por enfermeiros e médicos, permitindo a atuação através de procedimentos invasivos de suporte ventilatório e circulatório (Malvestio \& Souza, 2003).

São clientes desses serviços as operadoras de planos de saúde, o setor público de saúde e empresas privadas.

No caso da remoção de pessoas que sejam beneficiárias de planos de saúde, a regra de atendimento é definida pela ANS (Agência Nacional de Saúde, órgão regulador da saúde privada), e contempla a regulação médica, além da anuência do usuário ou de seu responsável (ANS, 2014). 
O setor público também consome esse tipo de prestação de serviço, de maneira complementar ao Serviço de Atendimento Móvel de Urgência (SAMU). Ao analisar o sistema brasileiro de atendimento aos casos de urgência, pode-se verificar várias questões estruturais, tais como: problemas com acesso, volume de leitos não suficiente para retaguarda, comprometimento nas redes de referência e questões relacionadas à formação profissional da equipe de atendimento. No início dos anos 2000, começaram a ser formuladas políticas que atendam a essas questões (Machado, Salvador, \& O'Dwyer, 2011). Essa deficiência do sistema abre portas para ações do sistema privado, especialmente nos âmbitos municipais, cujas estruturas são menos complexas e permitem uma melhor gestão da demanda.

As empresas em geral compõem a lista de clientes através da contratação do serviço de área protegida das suas instalações. Isso lhes dá a garantia de que todas as pessoas que circulam em sua estrutura possam ser brevemente atendidas na ocorrência de algum problema de saúde. Quando há um acionamento, a regra é que uma equipe de saúde esteja disponível para atendimento em até 30 minutos e, dependendo da gravidade do caso, seja ou não transferida para uma unidade hospitalar de saúde.

Ainda em relação aos contratantes desse serviço, em 2014, a Comissão de Constituição e Justiça e de Cidadania da Câmara dos Deputados aprovou o Projeto de Lei 5088/13 (Brasil, 2013), tornando obrigatória a permanência de ambulância e de profissional da área da saúde em lugares com grandes aglomerações - eventos, aeroportos, estádios e rodoviárias - para socorro imediato das vítimas. Essa condição abriu uma nova janela de oportunidade de oferta de serviços. A Figura 11 ilustra as entradas e saídas no macroprocesso de transporte terrestre de usuários. 


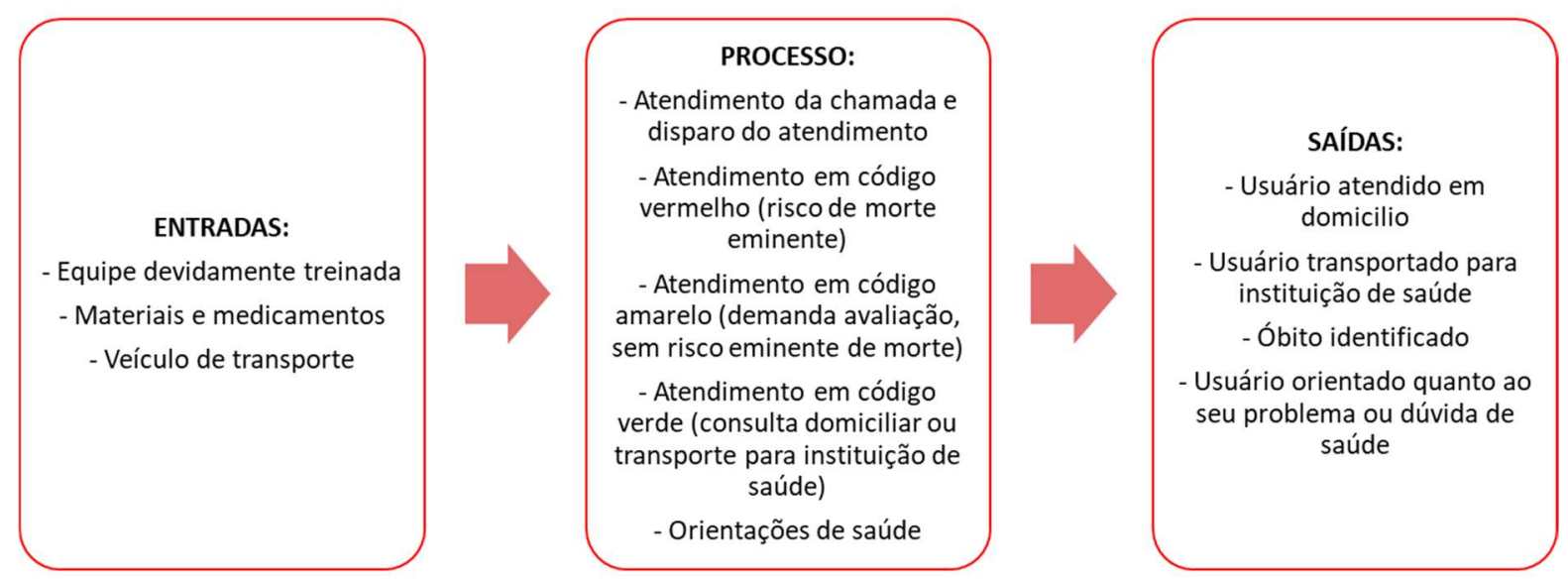

Figura 10. Macroprocesso de transporte terrestre de usuários. Fonte: elaborado pela autora

O processo consiste em atender os usuários que acessam o serviço através de central telefônica, definir o melhor recurso, disparar a equipe em um veículo especializado e com todos os insumos materiais necessários, além de acompanhar o desfecho.

A equipe que suporta essa operação é composta por Auxiliares de Regulação Médica (ARM), profissionais sem formação técnica em saúde, responsáveis pelo atendimento de $90 \%$ das chamadas em até 10 segundos. A partir do entendimento e registro da queixa do usuário, um algoritmo indica, com base em questões que apontem para a existência de situações que exponham os usuários a risco de vida, o tipo de recurso mais adequado a ser despachado.

Esses algoritmos apoiam esses profissionais na melhor decisão. As perguntas que norteiam a velocidade com que os recursos serão alocados estão relacionadas ao nível de consciência (ou seja, se o usuário do serviço está acordado e respondendo a estímulos) e ao padrão respiratório (que considera a existência ou não dos movimentos de inspiração e expiração). Note-se que a ausência de consciência e de movimentos respiratórios configuram os maiores riscos à vida e, portanto, requerem atuação imediata, com alocação prioritária dos recursos.

Entendido o cenário, entram em cena as equipes médica e de tráfego. $\mathrm{O}$ médico é o responsável por toda a tomada de decisão no processo de regulação do serviço de atendimento móvel de urgência (Resolução CFM Nº 2110/2014) e é quem, 
na prática, define o recurso a ser enviado. A equipe de tráfego é formada por profissionais com formação em logística e que, com apoio da tecnologia, se responsabilizam pelo envio, para o local de atendimento indicado no ato da chamada, do recurso que atenda os parâmetros técnicos ditados pelo médico.

A equipe que se desloca ao local do atendimento é composta por socorristas, técnicos em enfermagem, enfermeiros e médicos.

Os socorristas são responsáveis por dirigir o veículo caracterizado como ambulância. O pré-requisito para a contratação desses profissionais é ter carteira de motorista categoria $\mathrm{D}$ e curso de primeiros socorros.

O técnico em enfermagem, em conjunto com o socorrista, compõe a equipe que executa os atendimentos de baixa complexidade. Esse tipo de recurso é escolhido em situações em que o transporte para uma unidade de saúde se faz necessário e a condição clínica dos usuários não requeira cuidados intensivos.

O enfermeiro pode tanto compor uma equipe de suporte intermediário de vida (SIV), quanto o atendimento de alta complexidade (UTI móvel). No primeiro caso, a equipe é composta pelo enfermeiro e pelo socorrista; no segundo, por esses dois profissionais, juntamente com o médico. Esses atendimentos podem tanto solucionar o problema no local de acionamento da ambulância, quanto transportar usuários entre unidades de saúde.

O médico compõe a equipe de atendimento de alta complexidade (UTI móvel). 


\begin{tabular}{|c|c|}
\hline Tipos de casos & $\begin{array}{c}\text { Equipe empenhada no } \\
\text { atendimento }\end{array}$ \\
\hline $\begin{array}{c}\text { Atendimentos de baixa complexidade: restrições } \\
\text { de movimento, necessidade de oxigênio continuo }\end{array}$ & $\begin{array}{c}\text { Socorrista + Técnico em } \\
\text { Enfermagem }\end{array}$ \\
\hline $\begin{array}{c}\text { Atendimentos de média complexidade: } \\
\text { necessidade de monitorização cardíaca contínua, } \\
\text { necessidade de monitorização de sinais de } \\
\text { instabilidade clínica, atendimento inicial até a } \\
\text { chegada da equipe com médico }\end{array}$ & Socorrista + Enfermeiro \\
\hline $\begin{array}{c}\text { Atendimentos de alta complexidade: ventilação } \\
\text { mecânica, instabilidade clinica, uso de drogas } \\
\text { vasoativas }\end{array}$ & $\begin{array}{c}\text { Socorrista + Enfermeiro + } \\
\text { Médico }\end{array}$ \\
\hline
\end{tabular}

Figura 11. Características dos atendimentos e equipes empenhadas.

Fonte: elaborada pela autora.

Esse serviço se relaciona com os demais serviços da empresa atendendo seus usuários finais. No caso da assistência domiciliar, isso se dá quando há algum tipo de intercorrência no domicílio ou quando há necessidade de deslocamento para alguma unidade de saúde. No caso do gerenciamento de doentes crônicos, o serviço é acionado quando o usuário liga para a central de emergência para esclarecer alguma dúvida ou reportar alguma condição de saúde que requeira avaliação in loco.

O registro dessas ocorrências é feito no sistema de informação específico que apoia essa equipe, composto pelos seguintes dados:

- Nome completo e CPF do usuário elegível ao atendimento (o CPF é um dado obrigatório);

- Motivo gerador do acionamento;

- Descrição do atendimento e

- Finalização do atendimento (orientação telefônica, resolução na residência ou transferência para ambiente hospitalar).

A Figura 13 mostra o modelo do fluxo do processo de atendimento ao usuário da central de urgência. Como já foi explicitado anteriormente, esse usuário entra em contato com uma demanda de saúde e passa pelas equipes que compõe essa central, até ter o recurso adequado disponível. 


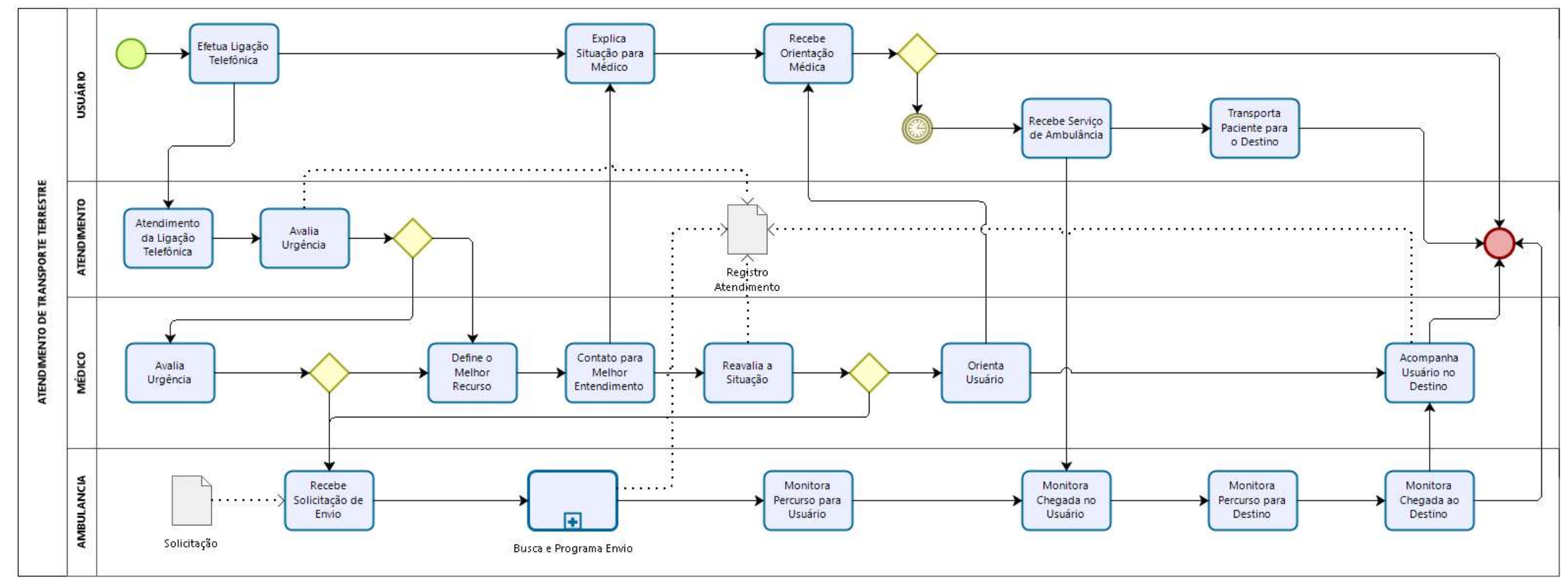

Figura 12. Fluxo de atendimento de solicitação de transporte terrestre. 
Em relação ao volume de chamadas no período 01 a 31/01/2019, foram recepcionadas 14.510 ligações, e dessas, 12.085 foram atendidas e 2.425 foram abandonadas na fila de atendimento.

A chamada foi gerada em duas origens: $62,1 \%$ por parte do próprio usuário e $37,9 \%$ por parte do cliente.

Em relação ao motivo da ligação:

- $38,2 \%$ solicita atendimento de emergência (ameaça imediata);

- $23,4 \%$ solicita atendimento de urgência (pode se tornar uma emergência se não tratada);

- $19,8 \%$ solicita agendamento de remoção e,

- $18,6 \%$ solicita sanar dúvidas de saúde.

Do total de chamadas recebidas, $43,3 \%$ foram transferidas para a equipe médica, que constituía o segundo nível de atendimento.

\subsubsection{Programas de Gerenciamento de doenças crônicas}

As chamadas doenças crônicas não transmissíveis (DCNT) são caracterizadas pela ausência de tratamentos considerados curativos, e, portanto, implicam em cuidados contínuos com a saúde. Elas são, atualmente, as principais responsáveis pela morbimortalidade das populações, trazendo impactos na qualidade de vida, produtividade e funcionalidade. São consideradas doenças multifatoriais, tendo os fatores de risco modificáveis, como tabagismo, etilismo, sedentarismo e alimentação não saudável, forte relação com o aparecimento e a evolução da doença (OPAS, 2011).

O gerenciamento de doença crônica se caracteriza pelo acompanhamento dos portadores de doenças, geralmente através de visitas domiciliares, ligações telefônicas, troca de mensagens eletrônicas ou envio de materiais informativos. $O$ objetivo é orientar sobre as questões que afetam diretamente a manutenção da estabilidade clínica e do ganho de qualidade de vida, apoiando as mudanças de hábito necessárias para frear ou desacelerar o processo de evolução da doença. 
Tal qual a assistência domiciliar, esse tipo de serviço não está no rol de procedimentos obrigatórios, porém é amplamente incentivado pela ANS, que, atualmente, vem promovendo políticas de incentivo, como o Programa de Qualificação da Saúde Suplementar e o Programa de Promoção da Saúde e Prevenção de Riscos e Doenças. O objetivo dessa ação é estimular a alteração nos papéis dos diversos atuantes da saúde suplementar, especialmente os gestores dos planos de saúde privados, que devem se tornar gestores de saúde; os prestadores de serviços, produtores de cuidado; os beneficiários, usuários com consciência sanitária e autonomia; e a ANS, órgão regulador cada vez mais qualificado e eficiente para regular um setor que objetiva produzir saúde (ANS, 2009).

São os resultados apresentados por esse tipo de programa que incentivam fortemente sua contratação. Segundo Veras (2012), quando se investe em prevenção de doenças crônicas, o retorno para cada dólar investido é de US\$2,9, i.e., uma relação de quase 3 para 1.

As maiores contratantes são as operadoras de planos de saúde e autogestões, que têm todos os seus esforços voltados para o controle de custo, uma vez que as margens de lucro estão cada vez mais reduzidas. Ultimamente, tem-se visto um movimento por parte das empresas na contratação de programas de gestão de crônicos para seus colaboradores. Isso porque os resultados também demonstram que os colaboradores saudáveis custam menos e produzem mais. A economia pode chegar a U\$ 6 para cada U\$ 1 investido (Berry, 2010).

A Figura 14 ilustra as entradas e saídas no macroprocesso de gerenciamento de usuários.
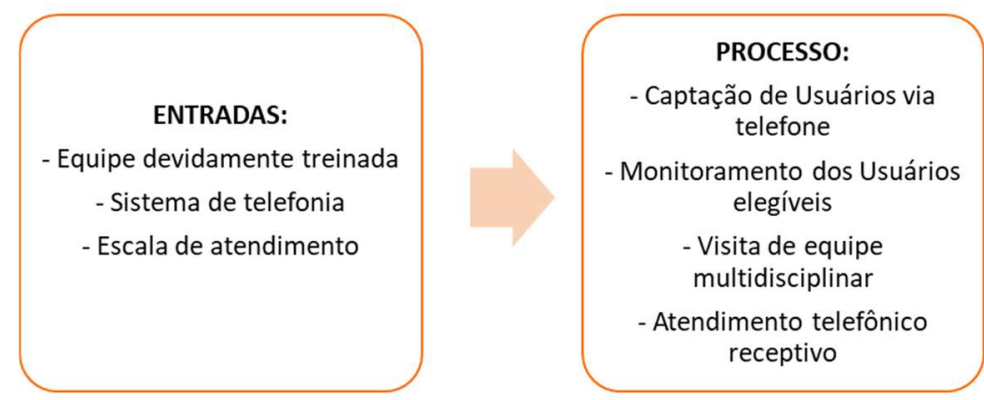

SAÍDAS:

- Usuário auto controlado

- Usuário educado a respeito das condições de saúde que o acometem

- Diminuição das visitas à

Pronto Socorro

- Diminuição de diárias de internação

Figura 13. Macroprocesso de gerenciamento de usuários crônicos 
O programa de acompanhamento de doentes crônicos tem início com a recepção de uma lista de possíveis usuários elegíveis ao programa enviada pelos clientes. Essa lista contém os dados cadastrais mínimos necessários para que se possa estabelecer contato por correspondência ou telefone com os usuários do serviço. Após o registro dessas informações no sistema de informação de apoio, uma equipe de distribuição envia um comunicado por correio com explicações sobre o funcionamento do programa e, na sequência, a equipe de captação inicia as tentativas de contato por telefone. Vale ressaltar o motivo pelo qual a equipe que faz a primeira ligação com o usuário é chamada de equipe de captação: esse primeiro contato tem o objetivo de convencer o usuário de que a permanência no programa pode trazer ganhos para a sua saúde e qualidade de vida. Portanto, é o momento de "captá-lo" para a permanência. Esse contato também tem a função de confirmar sua elegibilidade. Em havendo concordância e perfil, o usuário segue no acompanhamento.

A frequência das abordagens e os recursos alocados são definidos de acordo com o perfil traçado nessa primeira chamada. Quanto maior o risco de saúde e o grau de dependência para as atividades diárias, maior será a frequência e a complexidade dos recursos alocados, que podem variar de ligações telefônicas bimestrais a visitas médicas mensais.

Os usuários incluídos no programa recebem um número de telefone que lhes dá o benefício de uma central de atendimento $24 \mathrm{hs}$ por dia, 7 dias na semana, 365 dias por ano. Essa central é composta por enfermeiros treinados e habilitados para acolher o usuário e apoiá-lo na escolha do melhor recurso de saúde para o problema apresentado. Apenas cerca de $2 \%$ dos doentes acompanhados (de um total de 40.000 usuários) entra em contato todos os meses, e a principal motivação da chamada é esclarecer algum tipo de dúvida ou solicitar apoio na resolução de alguma demanda de saúde presente.

Nas situações em que o problema de saúde apresentado possa causar algum tipo de dano ao usuário, o enfermeiro deve acionar outra instância de atuação. Nesse caso, o usuário é transferido para o médico da central de regulação da equipe de transporte terrestre, que segue na tratativa do caso. A finalização do atendimento pode se concentrar na orientação médica ou, caso o usuário tenha esse recurso contratado e esteja dentro da área de abrangência, pode haver o encaminhamento de 
uma ambulância com médico para o atendimento domiciliar. Esse último, por sua vez, pode finalizar a ocorrência na residência, ou transferir o usuário para alguma unidade de saúde habilitada para tal.

As informações geradas nas intervenções com os usuários são registradas em sistemas próprios, tais como: registros de consultas médicas, medicamentos em uso, internações, hábitos de vida e adesão às orientações fornecidas pelo programa.

A equipe envolvida nos atendimentos era composta por enfermeiros, que se revezavam em escalas de $6 \mathrm{~h}$ e $12 \mathrm{hs}$ de trabalho. Durante o dia (8-20hs), 4 profissionais trabalhavam simultaneamente, enquanto 2 profissionais atuavam no período noturno, horário de menor demanda.

Da mesma forma que na central de atendimento de urgência, foram observadas ineficiências em relação a utilização dos recursos humanos nessa central. Pelo fato de as chamadas serem direcionadas sempre para um enfermeiro, esse passava a se responsabilizar inclusive pelo direcionamento ou resolução de demandas administrativas como, por exemplo, a solicitação de contato com o profissional que acompanha esse usuário, agendamento ou cancelamento de visitas domiciliares, ou mesmo chamadas feitas por engano. Outro ponto observado foi o fato de as centrais não terem um sistema de informação integrado, forçando que as demandas que necessitavam de direcionamento para a central de urgência entrem no mesmo fluxo de chamadas externas, resultando em retrabalho pela equipe e ineficiência ao usuário, que precisava explicar novamente suas demandas de saúde.

A Figura 15 mostra o fluxo do processo de atendimento dos programas de gerenciamento de doenças crônicas. Os usuários podem entrar em contato simplesmente para esclarecimento de uma dúvida de saúde, solicitação de contato com o profissional que o acompanha ou para solicitar apoio em alguma questão relacionada a sua saúde. Caso a demanda não possa ser resolvida pelo enfermeiro, esse encaminhará o atendimento para a central de emergência ou, frente a não elegibilidade, a encaminhará para o pronto socorro mais próximo da sua residência.

Em relação ao volume de chamadas no período de 01 a 30/11/2018, foram recepcionadas 3.757 ligações. Todas as chamadas partiram do próprio usuário ou de um familiar. 
Em relação ao motivo da ligação:

- $\quad 85,7 \%$ solicita esclarecimento sobre o serviço de monitoramento;

- $6,2 \%$ retorna um contato com o profissional de saúde e,

- $\quad 8,1 \%$ solicita sanar dúvidas de saúde. 


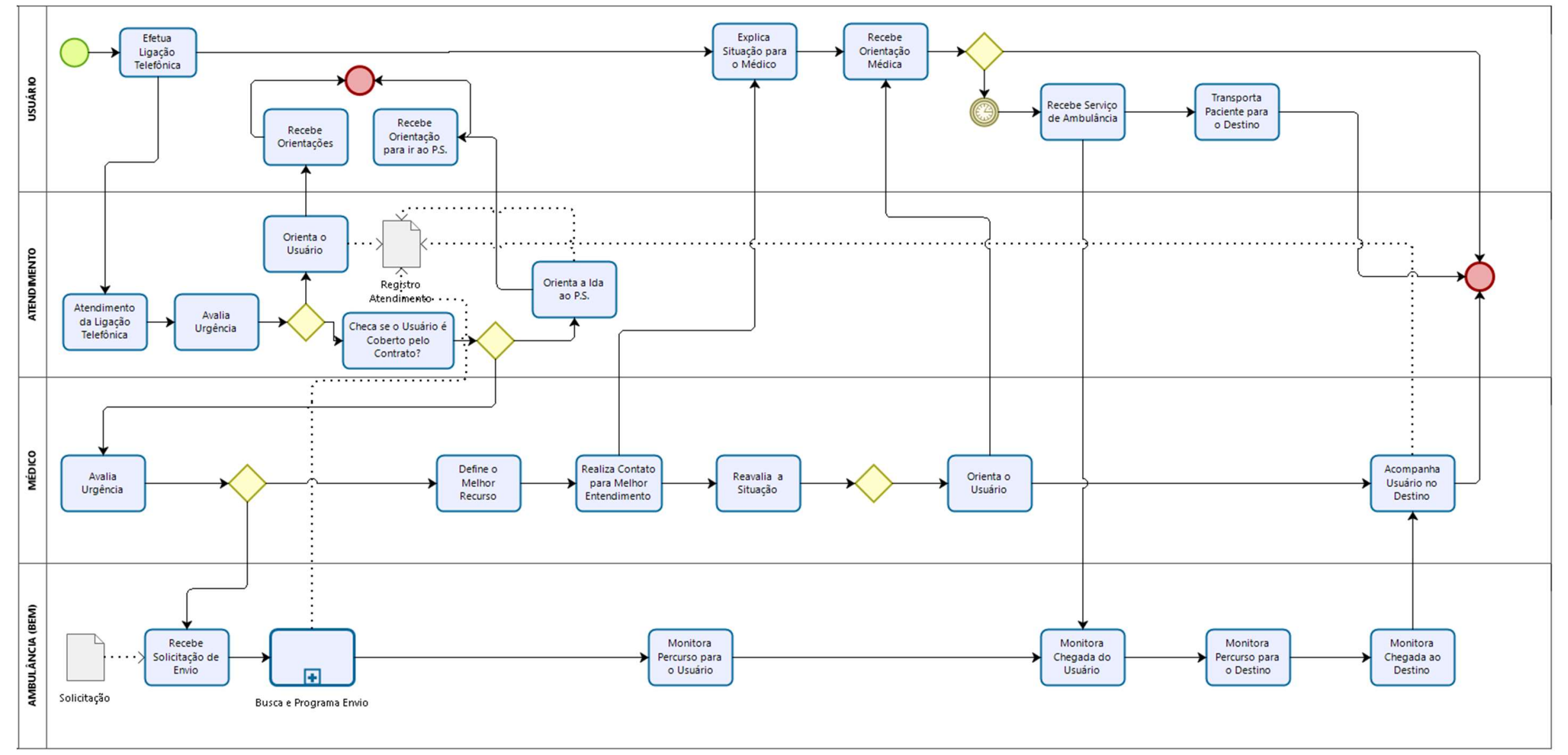

Figura 14. Fluxo de atendimento dos programas de gerenciamento de doenças crônicas 


\subsubsection{Internação domiciliar}

Os serviços de internação domiciliar, comumente conhecidos como Home Care (termo da língua inglesa que significa cuidado em casa), são constituídos por um conjunto de ações de prevenção e tratamento de doenças, reabilitação, paliação e promoção à saúde, prestados em domicílio, garantindo continuidade de cuidados (Ministério da Saúde, 2016).

No Brasil, o Serviço de Assistência Médica Domiciliar de Urgência (SAMDU), criado em 1949, foi a primeira iniciativa de assistência domiciliar. Na década de 1990, seguindo uma tendência mundial, surgiu o serviço organizado na forma de cuidado domiciliar (home care), concentrado em empresas privadas e nos grandes centros, cujo principal foco estava na prestação de serviço a um melhor custo (Feuerwerker, \& Merhy 2006).

Diferentemente dos serviços de transporte de usuários, o atendimento domiciliar não é um serviço obrigatório dentro do rol de procedimentos da Agência Nacional de Saúde. De acordo com a ANS (2016, p. 1), cumpre assinalar que a Lei $\mathrm{n}^{\circ}$ 9.656, de 1998, não inclui a assistência à saúde no ambiente domiciliar (Home Care) entre as coberturas obrigatórias. Para uso domiciliar, a lei garante apenas o fornecimento de bolsas de colostomia, ileostomia e urostomia, sonda vesical de demora e coletor de urina com conector (art. 10-B). Além disso, a Lei deixa explícito que, nos casos de terapia medicamentosa, o fornecimento de medicamentos para tratamento domiciliar não está contemplado dentre as coberturas obrigatórias (art. 10, inciso VI), exceção feita apenas para os medicamentos antineoplásicos orais Publicada em 02/01/2018 - para o controle de efeitos colaterais e adversos dos medicamentos antineoplásicos (art. 12, inciso I, alínea "c", e inciso II, alínea "g").

A judicialização, que consiste na tentativa de obter materiais, medicamentos, exames, cirurgias e tratamentos que não constam na lista do SUS e dos planos de saúde por meio de ações judiciais (Folha de S. Paulo, 2016) se tornou um meio para obrigar as operadoras de saúde a fornecerem esse tipo de serviço. Ainda segundo o jornal Folha de S. Paulo (Collucci, 2017), as decisões de primeira instância passaram de 42, em 2012, para 565, em 2016. Além disso, as de segunda instância aumentaram de 347 para 651 dentro desse mesmo período. O resultado demonstra que $90 \%$ das 
decisões têm desfecho favorável ao reclamante. Nesse período, ao avaliar o volume de empresas de Assistência Domiciliar no Estado de São Paulo, a evidência é que houve aumento de 138 para 299, o que significa que o número delas mais que dobrou.

De acordo com o último censo do Núcleo de Empresas de Atenção Domiciliar (NEAD) realizado em 2014, no país, mais de 1 milhão de pessoas são hospitalizadas e recebem cuidados ambulatoriais em casa. A pesquisa aponta, ainda, que cerca de $70 \%$ dos usuários são encaminhados pelas operadoras de saúde para o atendimento domiciliar, $26 \%$ pagam pelo serviço particular e apenas $4 \%$ são provenientes do serviço público de saúde.

A Figura 16 ilustra as entradas e saídas no macroprocesso de internação domiciliar de usuários.
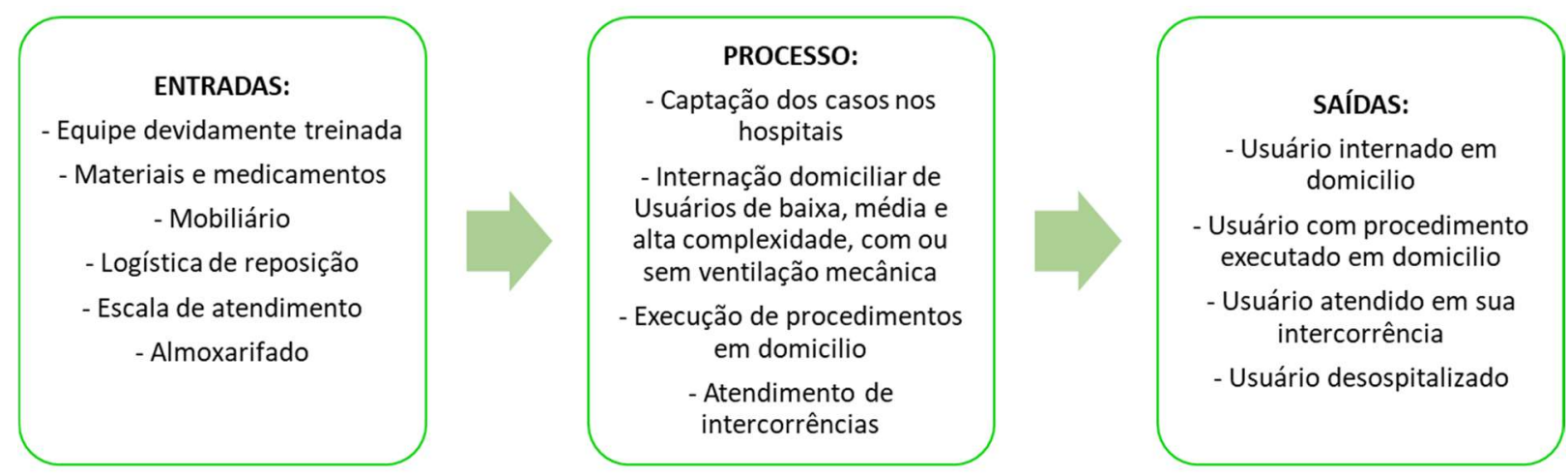

Figura 15. Macroprocesso de internação domiciliar. Fonte: elaborado pela autora.

O processo de atenção domiciliar consiste em recepcionar as demandas dos clientes, avaliar os usuários e definir quais recursos são necessários, montar a estrutura no domicílio, transportar o usuário da unidade hospitalar para o domicilio adaptado e acompanhar sua evolução ao longo da prestação de serviços.

A equipe que atua nesse atendimento é formada por profissionais administrativos, que suportam a equipe técnica composta por médicos, enfermeiros, fisioterapeutas, terapeutas ocupacionais, fonoterapeutas, assistentes sociais, psicólogos e nutricionistas.

A etapa inicial do atendimento ocorre com um pedido de avaliação solicitado pelos clientes. Essa avaliação prevê a visita de um enfermeiro habilitado no hospital 
de internação do usuário, com o objetivo de avaliar os recursos necessários para a implantação do atendimento domiciliar, tendo como base a condição clínica do paciente e os itens solicitados pelo médico responsável. De posse dessa avaliação, é possível compor um orçamento, para que o cliente valide o Plano de Assistência Domiciliar (PAD) e o aprove. Uma vez aprovado o orçamento, evolui-se para a organização do domicílio para a recepção do usuário. Os familiares ou responsáveis têm participação ativa nesse processo. A presença da equipe no domicílio varia de acordo com a indicação técnica. Em alguns casos, ela permanece por poucos dias, até o fim da terapêutica iniciada no ambiente hospitalar; em outros, permanece tempo suficiente para a reabilitação do paciente, e, em parte dos casos, inicia seu atendimento sem nenhuma perspectiva de alta. O tempo médio de internação dos usuários varia muito, podendo ser de apenas dois dias ou de até oito anos, como é o caso de maior permanência já registrada pela empresa em estudo.

Essa cadeia de atendimento inclui a logística de profissionais que atendem em domicílio e a entrega dos insumos necessários para os cuidados. Os mobiliários são entregues antes da transferência do usuário para a residência e sofrem pequenas alterações em sua composição ao longo da jornada da internação domiciliar, que depende da necessidade de manutenção ou de alterações clínico-terapêuticas que determinem novas necessidades ou intervenções.

Os materiais e medicamentos de uso diário são abastecidos a cada 15 dias. O início desse processo se dá com a visita de um enfermeiro no domicílio para inventário do estoque. Esse profissional preenche uma documentação no sistema de informação de apoio, indicando o volume de insumos disponíveis no domicílio para cada item necessário. A diferença entre o item inventariado e a quantidade necessária para a próxima quinzena gera uma Ordem de Serviço (OS). Essa OS é encaminhada pelo sistema informatizado para o Almoxarifado, cuja equipe é responsável por separar o material e enviar para as residências. O intervalo de tempo entre o inventário e a entrega dos materiais é de sete dias.

Não são raras as alterações de conduta por parte do médico responsável, ou mesmo as situações inesperadas, que são chamadas de intercorrências. Nesses casos, um aditivo orçamentário é executado, uma nova OS é gerada, e o prazo de entrega varia entre $24 \mathrm{hs}$ (para atender intercorrências clínicas) e 72hs (para situações não emergenciais). 
Esse processo também inclui uma logística reversa. Todo excedente de material e medicamento do domicílio retorna ao Almoxarifado, passa por um processo de avaliação técnica de qualidade e validade, e é reintegrado ao estoque para nova dispensação.

O canal de relacionamento com o usuário é composto por um número de telefone e um e-mail. A demanda é recepcionada por um profissional de saúde, responsável por acolher o familiar ou cuidador, decodificar a mensagem e dar a tratativa necessária para solução breve da demanda apontada. A maior porte das chamadas se refere a questões logísticas: recepção de materiais de uso hospitalar, medicamentos e presença dos profissionais.

O relacionamento com os usuários e o atendimento de suas demandas é registrado em um sistema de informações, estando subdividido em:

- Dados cadastrais do usuário em atendimento

- Dados contratuais do cliente (fonte pagadora)

- $\quad$ PAD (Programa de Assistência domiciliar, que resume o plano terapêutico estabelecido pela equipe multidisciplinar e foi aceito pelo cliente)

- Recursos humanos alocados no atendimento

- Insumos e equipamentos

- $\quad$ Fornecedores

Finalmente observou-se que não havia uma central de atendimento estruturada para os usuários da assistência domiciliar. O volume de chamadas também não era conhecido. O sistema de telefonia utilizado por essa equipe não fornecia elementos mensuráveis. Entretanto, considerando-se que $100 \%$ das ocorrências eram registradas em sistema de informação, pode-se concluir que o volume médio de chamadas era de 3.200/mês.

As ligações em horário comercial, eram atendidas por uma recepcionista, que transferia a chamada para a pessoa requerida pelo solicitante, e não exatamente àquela responsável pelo atendimento da demanda. Fora do horário comercial, as chamadas eram atendidas por uma enfermeira, que resolvia ou direcionava a demanda para a resolução no dia útil subsequente. 
As ligações se originavam dos usuários ou dos profissionais que atendem no domicílio. As solicitações variavam, indo desde comunicados sobre intercorrência clínica, a questões de desabastecimento de materiais e medicamentos. Não havia processos claros e estruturados de tratativas de solicitações, situação que sobrecarregava parte da equipe que, por perfil de resolutividade, acabava assumindo toda a demanda. Observou-se que essa situação gerava muito descontentamento por parte dos usuários, que, muitas vezes, precisavam acionar a área de ouvidoria para terem suas solicitações atendidas.

As ineficiências observadas nesse processo eram muitas, tendo grande impacto na qualidade assistencial. De todas as operações da empresa, essa era provavelmente a que requeria maior investimento em revisão de processos, infraestrutura e treinamento de pessoas.

A Figura 17 mostra o fluxo do processo de atendimento ao beneficiário em internação domiciliar. 


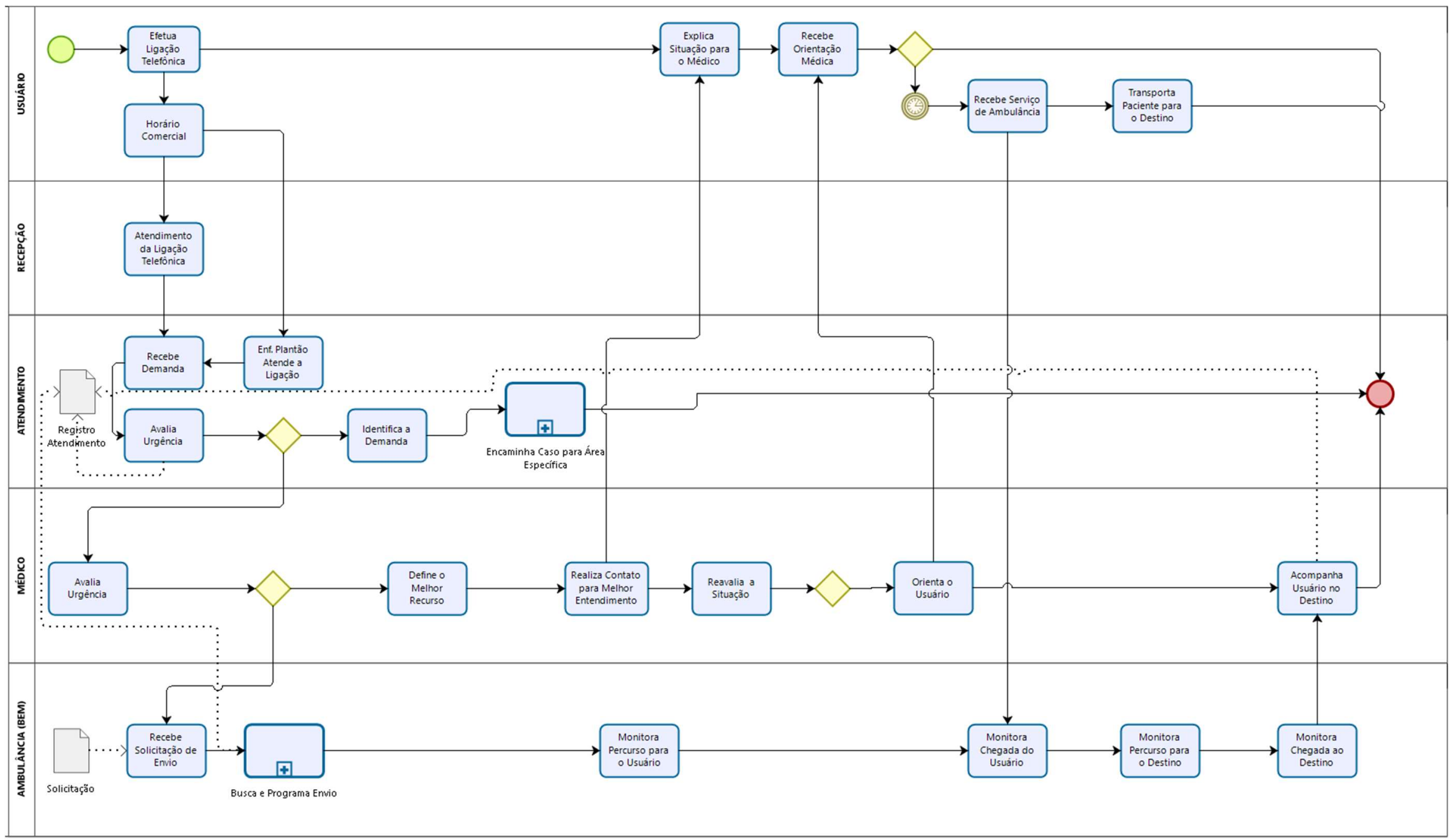

Figura 16. Fluxo de atendimento ao usuário em internação domicilio. Fonte: elaborado pela autora. 
Conforme exposto anteriormente, constatou-se haver ineficiência de recursos humanos, quando foram analisadas as centrais separadamente. Além disso, a falta de processos claros e estruturados afetava diretamente a qualidade do atendimento aos usuários e, por consequência, o nível de satisfação dos clientes. Vale ressaltar que as deficiências observadas provavelmente também levam a um custo mais alto, uma vez que os recursos não são utilizados de forma otimizada, observando-se ociosidade em parte das equipes e sobrecarga de trabalho em outras.

O conceito e todas as implicações do termo padronização advêm da revolução industrial, cujo desafio consistia na implementação da força da máquina que, muitas vezes, substituía o homem. Nesse contexto, padronizar os processos fabris objetivava a obtenção de produtos uniformes, elevando os padrões de qualidade do produto (Martins \& Laugeni, 1999). Fazendo uma analogia deste conceito com a estruturação de uma central de atendimento de múltiplos serviços, a padronização possibilitaria aumento de eficiência e a convivência de diferentes operações sob uma única gestão. Analisando os três processos de atendimento, foi possível observar muitas semelhanças que facilitariam sua unificação e padronização.

Entre os dias 14/01/2019 e 21/01/2019, foram analisadas as chamadas telefônicas realizadas na operação da assistência domiciliar, de forma que fosse possível entender volume e motivos que faziam os usuários, profissionais e fornecedores a ligarem na empresa.

Em relação ao volume de atendimentos no período especificado, essa operação não fazia parte da plataforma de telefonia das centrais de atendimento e, portanto, esse dado não pode ser conhecido.

Em relação ao motivo da ligação, o levantamento de dados se deu por meio do formulário apresentado a seguir, especialmente elaborado para essa finalidade. 


\begin{tabular}{|c|c|}
\hline \multicolumn{2}{|r|}{ ORIGEM DA CHAMADA } \\
\hline$\square$ & Cuidador ou Paciente \\
\hline$\square$ & Funcionário \\
\hline$\square$ & Fornecedor ou Prestador de Serviços \\
\hline$\square$ & Clientes \\
\hline \multicolumn{2}{|r|}{ TEMA DA CHAMADA } \\
\hline$\square$ & Captação/Implantação \\
\hline$\square$ & Escala de profissionais ou visita domiciliar \\
\hline$\square$ & Intercorrência Clínica \\
\hline$\square$ & Equipamento/Mobiliário \\
\hline$\square$ & Oxigênio \\
\hline$\square$ & Materiais e Medicamentos \\
\hline$\square$ & Exames/Remoções \\
\hline$\square$ & Dúvidas Técnicas \\
\hline$\square$ & Ouvidoria \\
\hline$\square$ & Lixo Hospitalar \\
\hline$\square$ & Outros \\
\hline \multicolumn{2}{|r|}{ DESCRIÇÃO BREVE DO MOTIVO DA CHAMADA } \\
\hline \multicolumn{2}{|r|}{ A DEMANDA FOI RESOLVIDA? } \\
\hline$\square$ & Sim \\
\hline$\square$ & Não \\
\hline \multicolumn{2}{|r|}{ QUAIS RECURSOS FORAM UTILIZADOS? } \\
\hline$\square$ & Somente consultar o sistema \\
\hline$\square$ & Consultar informação com a equipe técnica ou de operação \\
\hline$\square$ & Consultar fornecedor externo ou prestador de serviço \\
\hline$\square$ & Resolvi sozinho(a) (sou detentor da informação) \\
\hline & PARA QUAL ÁREA VOCÊ TRANSFERIU A DEMANDA? \\
\hline
\end{tabular}

Figura 17. Formulário de levantamento de dados de demandas de usuários por telefone no serviço de assistência domiciliar.

Fonte: elaborado pela autora.

O primeiro bloco (Origem da chamada) elencou os quatro grandes agentes dessa cadeia: usuários e seus familiares, equipe de saúde que atende o usuário, fornecedores que prestam serviços para a empresa e os clientes que os contratam.

O segundo bloco (Tema da chamada), buscou elencar os motivos que fazem com que esses agentes entrem em contato com a empresa por telefone. A definição dos temas considerou a fase do usuário no atendimento (pré- 
atendimento, atendimento e alta), bem como a divisão das equipes operacionais no atendimento das demandas desses agentes.

O terceiro bloco (Descrição breve do motivo), considerou a necessidade de entender as demandas que se encaixavam em outros temas previamente definidos.

O quarto bloco visou avaliar se a demanda havia sido resolvida durante a chamada telefônica, se havia a necessidade de repasse para outros agentes, ou até mesmo transferir a chamada para outra equipe.

O quinto bloco (Utilização de recursos), avaliou a autonomia ou capacidade do receptor da demanda em resolvê-la.

E, por fim, o último bloco mapeou o volume de chamadas transferidas para outros setores de atendimento.

As lideranças de cada processo de atendimento foram as responsáveis por controlar diariamente a adequada coleta dos dados, garantindo que seria obtida a melhor informação possível para qualificar as demandas dos usuários. Vale ressaltar que se trata de uma operação bastante agitada e intensa, cujas demandas muitas vezes são emergenciais e requerem atuação imediata. Por isso, a importância dessa ação foi reforçada junto a essa equipe, de forma que a perda de registro fosse a mínima possível. O levantamento dos dados durou sete dias, de forma que fosse possível avaliar a demanda nos sete dias da semana.

Nesse período, foram classificadas 618 chamadas. Entre elas, 410 $(53,5 \%)$ continham todos os campos preenchidos nos formulários, razão pela qual optou-se em utilizar essa amostra de dados para a sequência do trabalho de análise.

A Tabela a seguir demonstra a origem das chamadas, sendo possível perceber que mais da metade das demandas parte das residências, por solicitações dos usuários. 
Tabela 1

Origem das chamadas da atenção domiciliar.

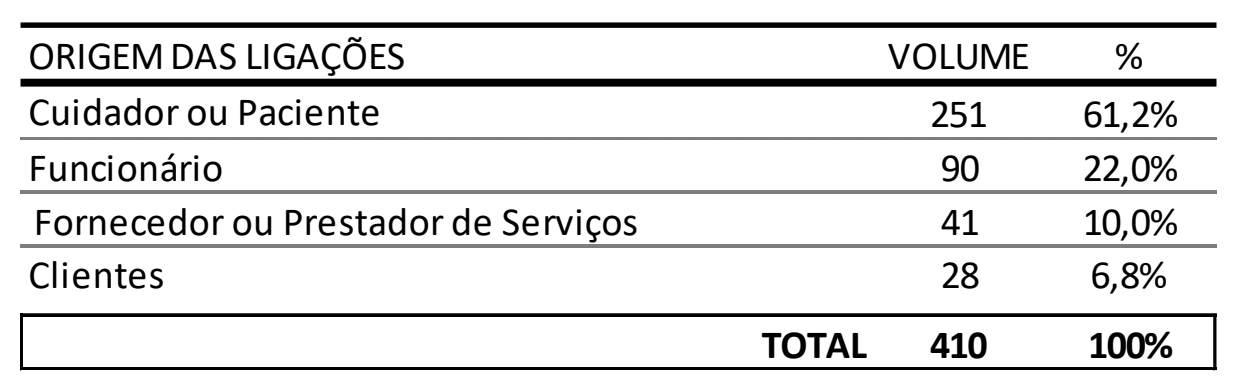

Nota: Fonte: elaborado pela autora.

É dentro da residência que a prestação do serviço domiciliar acontece. É lá que está o usuário alvo do atendimento; é até lá que os profissionais se deslocam para prestar a assistência e é lá que os fornecedores entregam os insumos necessários para que o atendimento ocorra. Portanto, era esperado que a maioria das chamadas partissem dessa origem.

Desconsiderando a opção "outros motivos", o processo de Captação e Implantação concentra o maior volume de chamadas, o que pode ser explicado pelo fato de ser uma etapa que agrega múltiplos agentes (cliente, hospital, família, fornecedores de equipamentos, fornecedores de materiais e medicamentos, equipe de transporte, médico responsável, etc.).

$\mathrm{Na}$ sequência, foram identificadas demandas relacionadas a materiais e medicamentos e à escala de profissionais. Levando-se em conta que a assistência domiciliar pode ser considerada uma ação logística de entrega de insumos materiais e humanos para executar um plano de cuidados, também faz sentido que esses sejam temas frequentes de chamadas. 
Tabela 2

\section{Motivo das chamadas}

\begin{tabular}{|c|c|c|}
\hline TEMAS & VOLUME & $\%$ \\
\hline Outros & 84 & $20,5 \%$ \\
\hline Captação/Implantação & 80 & $19,5 \%$ \\
\hline Materiais e Medicamentos & 66 & $16,1 \%$ \\
\hline Escala de profissionais ou visita domiciliar & 62 & $15,1 \%$ \\
\hline Oxigênio & 38 & $9,3 \%$ \\
\hline Intercorrência Clínica & 30 & $7,3 \%$ \\
\hline Equipamento/Mobiliário & 24 & $5,9 \%$ \\
\hline Exames/Remoções & 17 & $4,1 \%$ \\
\hline Dúvidas Técnicas & 9 & $2,2 \%$ \\
\hline Ouvidoria & 0 & $0,0 \%$ \\
\hline Lixo Hospitalar & 0 & $0,0 \%$ \\
\hline & TOTAL & $100 \%$ \\
\hline
\end{tabular}

Nota: Fonte: elaborado pela autora.

A capacidade de resolutividade da equipe de atendimento também foi mapeada pela coleta de dados.

Analisando os dados coletados, chamou a atenção o baixo índice de resolutividade. Das 410 chamadas avaliadas, apenas 213 foram solucionadas imediatamente. As outras 197 necessitaram de alguma ação ou busca de informação para sua completa resolução. Essa não resolutividade em primeiro nível aumenta a demanda da equipe e torna esse serviço menos eficiente. Além disso, considerando que o sistema de informação utilizado pela equipe não permite inserção do prazo para o retorno ao usuário, esse volume de pendências exige um controle paralelo por parte da equipe, evitando, assim, manifestações de insatisfação por parte dos usuários pelo elevado tempo de resposta.

Os baixos índices de resolutividade estavam relacionados a falta de treinamento da equipe, ausência do registro das instruções de trabalho e da complexidade das demandas, que muitas vezes requerem uma intervenção multidisciplinar. 


\begin{tabular}{|c|c|c|c|}
\hline A DEMANDA FOI RESOLVIDA? & & VOLUME & $\%$ \\
\hline Sim & & 213 & $52,0 \%$ \\
\hline Não & & 197 & $48,0 \%$ \\
\hline & TOTAL & 410 & $100 \%$ \\
\hline
\end{tabular}

Nota: Fonte: elaborado pela autora.

Em relação à fonte da informação que é passada no ato da chamada, o procedimento de coleta de dados permitiu constatar que não é simples a atividade de busca de informações para atender uma demanda do usuário. $\mathrm{Na}$ maioria dos casos, o sistema não oferecia subsídios para o entendimento da questão apontada e o profissional precisava consultar um colega ou o seu gestor. O fato de não haver $100 \%$ das informações registradas no sistema obrigava que cada um dos elementos da equipe tivesse que compor sua própria base de conhecimento.

Em apenas 6\% das demandas, foi possível finalizar o atendimento tendo como base informações inseridas no sistema. O reflexo disso é uma lentidão no retorno da demanda ao usuário, além da falta de padronização, o que pode levar a diferenças no padrão de atendimento da empresa, com variação na qualidade.

Tabela 4

Fonte da informação passada durante a chamada

\begin{tabular}{lcc}
\hline FONTE DA INFORMAÇÃO & VOLUME & $\%$ \\
\hline Consultar informação com a equipe técnica ou de operação & 201 & $49,0 \%$ \\
\hline Resolvi sozinho(a) (sou detentor da informação) & 139 & $33,9 \%$ \\
\hline Consultar fornecedor externo ou prestador de serviço & 45 & $11,0 \%$ \\
\hline Somente consultar o sistema & 25 & $6,1 \%$ \\
\hline \multicolumn{1}{|c}{ TOTAL } & $\mathbf{4 1 0}$ & $\mathbf{1 0 0 \%}$ \\
\hline
\end{tabular}

Nota: Fonte: elaborado pela autora. 
Tabela 5

Volume e características de chamadas

\begin{tabular}{|c|c|c|c|}
\hline Processo & Volume chamadas & Principais motivos & $\%$ \\
\hline \multirow{4}{*}{$\begin{array}{l}\text { Assistência } \\
\text { Domiciliar }\end{array}$} & \multirow{4}{*}{-} & Captação/Implantação & $19,5 \%$ \\
\hline & & Materiais e Medicamentos & $16,1 \%$ \\
\hline & & Escala de profissionais ou visita domiciliar & $15,1 \%$ \\
\hline & & Oxigênio & $9,3 \%$ \\
\hline \multirow{4}{*}{$\begin{array}{l}\text { Transporte } \\
\text { de usuários }\end{array}$} & \multirow{4}{*}{14.510} & Emergência & $38,2 \%$ \\
\hline & & Urgência & $23,4 \%$ \\
\hline & & Remoção & $19,8 \%$ \\
\hline & & Dúvidas de Saúde & $18,6 \%$ \\
\hline \multirow{3}{*}{$\begin{array}{l}\text { Gestão de } \\
\text { Crônicos }\end{array}$} & \multirow{3}{*}{3.757} & Esclarecimento sobre o serviço & $85,7 \%$ \\
\hline & & Dúvidas de Saúde & $8,1 \%$ \\
\hline & & Retorno de uma ligação não atendida & $6,2 \%$ \\
\hline
\end{tabular}

Nota: Fonte: elaborada pela autora.

\subsection{Proposta para o novo processo de atendimento ao usuário}

A partir da análise e da revisão dos processos de atendimento que foram realizadas, este estudo procurou elaborar uma nova proposta de processos, visando à otimização da utilização dos recursos, ao aumento da eficiência operacional e à entrega de maior valor ao usuário.

A nova proposta está graficamente representada na Figura 18. A partir de um canal único de atendimento, os usuários dos serviços acessariam uma central de atendimento. O primeiro nível, composto por um profissional com formação em nível médio, devidamente treinado no atendimento telefônico, entenderia a natureza da demanda geradora da chamada e tomaria a decisão de transferir ou não imediatamente a ligação para uma equipe técnica. Em caso de não transferência, a demanda poderia ser tratada pelo próprio atendente e registrada no sistema, ou direcionada para a equipe responsável pela sua tratativa, que atuaria conforme os SLAs de atendimento. Os fatores que influenciam no prazo de resposta estão ligados ao impacto na estabilidade clínica 
do usuário. Quanto maior o impacto, menor o prazo de atendimento por parte da equipe. 


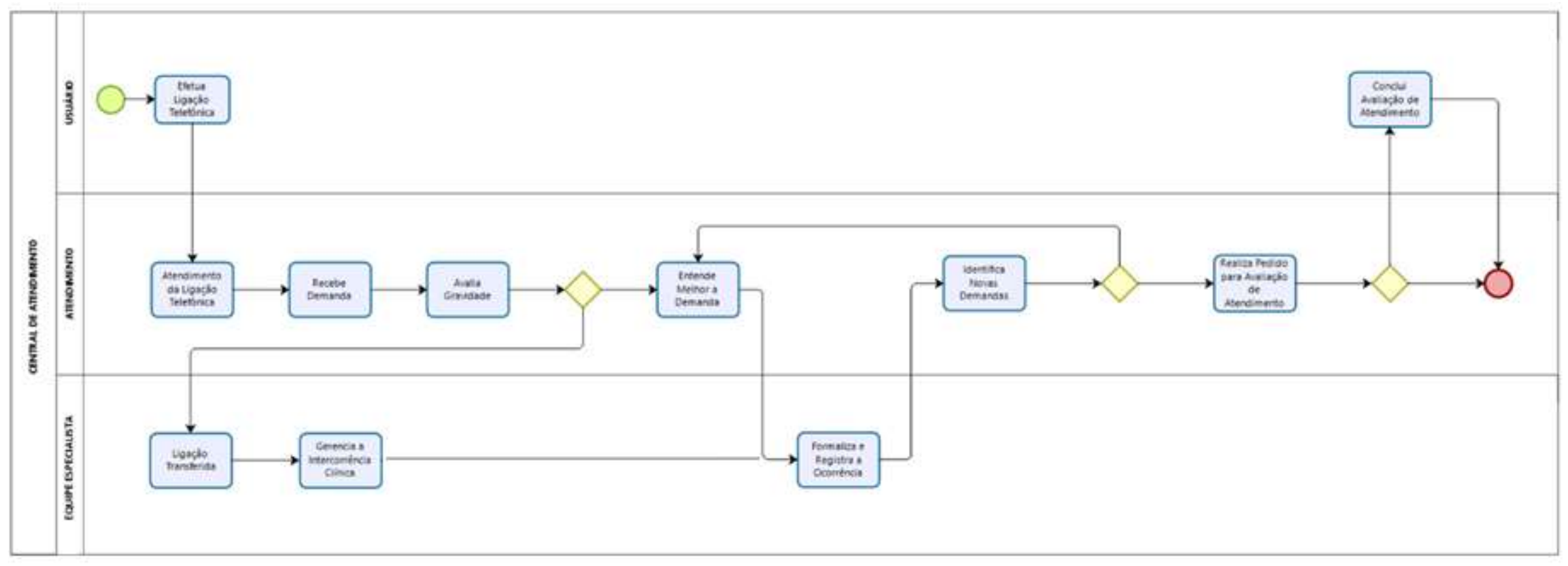

Figura 10. Novo modelo de atendimento ao usuário. Fonte: elaborado pela autora. 
Considerando que, originalmente, a operação de atendimento domiciliar não contava com uma central de atendimento telefônico, não seria possível a sua integração com as demais áreas operacionais da empresa.

Após o entendimento de que essa estratégia poderia trazer consideráveis ganhos de eficiência para a empresa, estabeleceu-se como foco desse estudo de caso a implementação da central de atendimento ao usuário.

\subsection{Implementação da central de atendimento}

A primeira ação da pesquisa constituiu-se no mapeamento dos processos operacionais de atendimento ao usuário das três unidades de negócios da empresa, de forma que fosse possível identificar oportunidades de atuação, com o redesenho da operação, objetivando ganho em eficiência.

Essa ação possibilitou o entendimento de que os níveis de maturidade das centrais de atendimento eram distintos e, portanto, a sua unificação imediata não seria possível. Dentro desse contexto, implantar uma central única de recepção das demandas da assistência domiciliar - cujos custos correspondem a $65 \%$ de toda a despesa da empresa, fazendo desse o maior ponto de oportunidade para identificação e diminuição dos desperdícios - seria prérequisito para um projeto posterior de unificação das centrais.

O planejamento da implementação da central foi dividido em três blocos:

1. Tecnologia: ferramentas necessárias para a implementação da central de atendimento aos usuários;

2. Pessoas: equipe necessária e treinamento para iniciar os atendimentos e

3. Processos: fluxos de direcionamento das demandas recepcionadas.

$\mathrm{Na}$ fase que antecedeu a implantação da central de atendimento, as pessoas estavam convencidas de que o formato estabelecido não era o ideal. Havia muita reclamação dos usuários de que a empresa era "uma bagunça", e que era sempre muito difícil ser atendido e ter retorno das demandas, sendo 
preciso insistir muito para ter respostas concretas. Apesar de todas as evidências de que algo de diferente precisava ser feito, os envolvidos demonstraram muita resistência na implementação do novo modelo. O período entre a finalização do planejamento das ações e a implementação propriamente dita foi de seis meses. A data de mudança foi adiada quatro vezes e, se não fosse por uma certa imposição do gestor, teria sido postergado ainda mais o início de seu funcionamento. Ora o discurso para mudança de data estava vinculado à imaturidade para trabalhar no novo modelo, ora baseava-se no fato de que os usuários não estavam acostumados a não serem atendidos por determinado colaborador. Havia, ainda, a alegação da saída de férias de algum representante da equipe.

\subsubsection{Novo sistema de telefonia}

Para que a central de atendimento fosse implementada, as seguintes funcionalidades foram requisitadas à equipe de tecnologia:

- $\quad$ Novo número de telefone que fosse divulgado para todos os usuários ativos. Considerando a abrangência geográfica em mais de um estado e muitos municípios com DDD distintos, optou-se por um 4005, de forma que o custo para os usuários fosse de uma chamada local para telefonia fixa.

- Plataforma de call center com gestão de filas de espera, chamadas gravadas e possibilidade de monitoramento on line das ligações.

Percebeu-se que uma das grandes preocupações das lideranças em trabalhar nesse novo modelo era a possibilidade de um usuário realizar alguma solicitação crítica para a empresa, como a ausência de algum medicamento, ou até mesmo o surgimento de sintomas que requeiram intervenção imediata, e a resposta não acontecer dentro de um tempo adequado, causando algum dano a sua saúde. 
Visando mitigar esse risco, tomou-se a decisão de inserir no sistema de telefonia uma URA (Unidade de Resposta Audível), que permitiria ao usuário escolher entre duas opções: comunicar emergência em saúde ou aguardar para ser atendido. As chamadas que tratariam de emergência teriam prioridade na fila e seriam imediatamente transferidas para a equipe técnica de enfermeiros e médicos, garantindo identificação rápida do problema e agilidade na execução das ações necessárias para manter o usuário em segurança.

\subsubsection{Revisão do Sistema de Informação}

Considerando que grande parte das demandas seriam recepcionadas por uma equipe, mas tratadas e resolvidas por outra, foi preciso estruturar a forma como essa comunicação seria feita internamente.

O atual sistema de informação permitia o registro de ocorrências, que eram divididas por categorias de atendimento. Convencionou-se que esse módulo seria o local em que a informação seria transacionada. Para isso, foi criado e divulgado um documento com os prazos de atendimento para cada tipo de solicitação.

Ainda assim, as lideranças entenderam que o processo seria frágil, pois não seria possível estabelecer prioridades. Com base nesse risco, foi realizado um ajuste no sistema de informação, adicionando uma categoria de demanda que foi chamada "Iniciar Tratativa Urgente". Dessa forma, quando a equipe responsável por dar a tratativa à ocorrência recebesse a demanda, saberia que aquela demanda havia chegado e ainda não tinha sido avaliada. Após o início do atendimento, esse status deveria ser modificado para 'Em atendimento da demanda', ou para 'Demanda atendida'.

A empresa utiliza basicamente dois sistemas de informação para dar suporte a sua operação: o Sistema ERP Protheus (fornecido pela Totvs) e o Sistema S2 (desenvolvido internamente). Conforme o diagnóstico da consultoria, ambos apresentavam oportunidades de melhoria na sua utilização. A Figura 19 demonstra as principais deficiências diagnosticadas. 
Não possui o cadastro corretos de materiais e medicamentos que permita otimizar processo de compras Não permite a realização de Mapa de Cotaçăo via sistema;

C Não é realizado custeio por contrato e serviço;

Controle de orçamento realizado no Excel

Sistema não realiza conciliações de impostos, provisōes e contabilização (fechamento)

C Não há controle de propostas e contratos

Previsão de compras com informaçöes divergentes;

Inviabilidade de atualizações e melhorias de forma rápida;

Impossibilidade de integração com plataforma mobile

Linguagem de programaçấo ultrapassada e sem documentação

$\Rightarrow$ Planejamento de escala realizado em planilha paralela

Dados operacionais e financeiros desatualizados ou não confiáveis (Ex. Escala, Estoque, Faturamento...)

Ausência de relatórios em formato que permita a gestão operacional (Ex. $n^{\circ}$ de usuários ativos Informar)

Códigos de produtos (MatMed) incompativeis entre sistemas;

Processo de Escala (S2) não conversa com o sistema de folha Protheus;

C Processos de Gente e Gestäo nào são realizados em nenhum dos sistemas:

Dificuldade de conciliação de números de inventário;

Divergência na integração de pedidos de compra

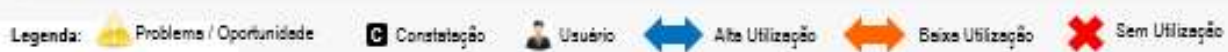

Figura 11. Oportunidades de melhoria nos sistemas de suporte diagnosticadas pela Consultoria. Fonte: Relatório da Consultoria.

Os problemas identificados na figura 19 trazem grande impacto para a gestão do negócio. Um exemplo está relacionado à base de cadastro de produtos no ERP. Como os produtos não continham os mesmos códigos e apresentações nos dois sistemas, chegar à informação final de custo por usuário atendido era uma tarefa que requeria muita manipulação de base de dados externa ao sistema, consumindo um tempo elevado que, além de tornar a operação custosa, tornava a análise dos dados lenta e dependente do envolvimento de pessoas especializadas.

Além disso, o sistema de informação da empresa em estudo não permitia a interoperabilidade entre os serviços, bem como não oferecia nenhuma facilidade para os usuários na alteração de parâmetros e inserção de novos fluxos de trabalho.

Outra decisão a mencionar, dada a sua relevância, foi a de substituir o sistema de informação que dá suporte ao trabalho da equipe de atendimento. $O$ sistema até então foi desenvolvido pela própria empresa, ao longo dos últimos oito anos, para atender especificamente ao negócio. Suas funcionalidades contemplam as especificidades de cada serviço e acompanharam a evolução de cada um deles. Do ponto de vista do colaborador, o sistema atendia às 
necessidades. Do ponto de vista de tecnologia, o sistema estava construído em uma linguagem ultrapassada, sua documentação era incompleta e sua manutenção requeria muito esforço e conhecimento do negócio, elevando os custos de manutenção. E, por fim, do ponto de vista do negócio, o sistema não acompanhou a velocidade da evolução tecnológica do mercado e, portanto, tornava a melhoria de processos e criação de novos serviços um processo lento e burocrático.

Analisando o cenário descrito acima, a direção da empresa tomou a decisão de buscar um sistema de mercado que atendesse a demanda dos diferentes segmentos de atuação do negócio, que partisse de uma arquitetura e linguagem mais modernas e, especialmente, que permitisse o consumo de atualizações advindas da colaboração de uma comunidade muito maior que aquela presente na empresa. Foi, então, feita uma RFP (Request For Proposal) e três empresas enviaram suas propostas. Passada a fase de validação do escopo e de análise de preço, uma delas foi selecionada. O processo de implementação foi iniciado em fevereiro de 2019, com data prevista de finalização para setembro de 2019.

\subsubsection{Revisão das atividades}

De acordo com o dicionário online Houaiss de Português, uma atividade pode ser entendida como a ocupação de uma pessoa. Já um processo é considerado uma atividade ou um conjunto delas que toma um input (entrada), adiciona valor e fornece um output (saída) ao cliente (Harrington, 1991).

Há autores que afirmam que a essência dos processos é a coordenação das atividades (Graham e LeBaron, 1994). Portanto, a atividade é parte fundamental do valor que uma empresa quer oferecer ao mercado.

Essas equipes eram divididas em:

> Núcleo 1 de atendimento: concentrava a gestão dos usuários de um único cliente, feita por enfermeiros e assistentes operacionais; 
Núcleo 2 ou Núcleo diversos: realizava a gestão de todos os demais clientes que, somados, igualavam em volume ao núcleo 1 , também composto por enfermeiros e assistentes operacionais;

Equipe multidisciplinar: todos os profissionais especialistas da equipe, responsáveis por avaliar os usuários sob a sua ótica de atuação: médicos, fisioterapeutas, fonoaudiólogos, nutricionistas, farmacêuticos, assistentes sociais e psicólogos;

> Gestão de escala: equipe responsável por distribuir os profissionais nas escalas de atendimento das residências e,

> Contas médicas: equipe responsável por reunir toda a documentação comprobatória para o faturamento.

Para avaliar a ocupação das pessoas por atividades executadas, foi executada a seguinte dinâmica com os colaboradores:

1. A primeira etapa consistiu na convocação das pessoas para reuniões de trabalho, separadas por áreas de atuação, sendo: Núcleo 1, Núcleo 2, Equipe Multidisciplinar, Equipe Médica, Gestão de Escala e Contas Médicas. Considerando que essas equipes estão divididas nas filiais SP e RJ, as reuniões se replicaram em cada unidade.

2. A segunda etapa contemplou o mapeamento de todas as atividades executadas por cada equipe, incluindo ações que consideravam que deveriam ser executadas por outras equipes. Durante essa dinâmica, cada integrante da equipe escreveu em "post-its" as atividades que compunham o seu dia a dia.

3. A terceira etapa da dinâmica correspondeu à leitura e entendimento de todas as atividades por um líder.

4. Na quarta etapa, as atividades afins foram agrupadas em macroprocessos de trabalho e foram redirecionadas para outras equipes as atividades que não compunham o objetivo final de entrega da equipe em questão.

5. Na quinta etapa, estabeleceu-se um líder para cada grupo de atividades, de forma que fosse possível engajar todos, 
acompanhar a execução das atividades e oferecer feedback individual sobre os resultados alcançados.

Abaixo, é apresentada uma tabela que compara o volume de atividades por equipe antes e depois da intervenção:

Tabela 6

Comparação do volume de atividades pré e pós revisão.

\begin{tabular}{|c|c|c|}
\hline ÁREA & ATIVIDADES (PRÉ) & ATIVIDADES (PÓS) \\
\hline Núcleo 1 & 82 & 81 \\
\hline Núcleo 2 & 96 & 86 \\
\hline Equipe Multidisciplinar & 195 & 221 \\
\hline Gestão de Escala & 35 & 38 \\
\hline Contas Médicas & 56 & 38 \\
\hline
\end{tabular}

Nota: Fonte: elaborado pela autora.

Proporcionalmente ao volume de atividades, a equipe de contas médicas foi a que apresentou a maior distorção entre o que vinha executando e o que deveria executar para a entrega de seus resultados. Vale ressaltar que essa equipe é a guardiã dos prazos das entregas de documentação aos clientes, fase que antecede a entrega dos faturamentos. $O$ fato de serem pressionados para o cumprimento desses prazos fazia com que assumissem a execução de todas as atividades que não estavam sendo realizadas pelos responsáveis no prazo previsto. Após esse diagnóstico, um novo alinhamento interno ocorreu, de forma que os prazos fossem atendidos nas diversas áreas da operação, sem gerar impactos para essa equipe.

\subsubsection{Reestruturação da equipe de atendimento}


Conforme já exposto anteriormente, o volume de ligações não era uma informação disponível, e por essa razão, havia risco de sub ou superdimensionamento da equipe de atendimento.

Em relação à equipe que atenderia a opção 1 da URA, o dimensionamento se deu pelo volume de intercorrências clínicas atendidas historicamente pela empresa, registradas como Ocorrências no sistema de informação. Com base nesse volume, estruturou-se um time com 1 profissional nas $24 \mathrm{hs}$ do dia, compondo uma equipe de 4 profissionais. Não houve contratação externa, e sim um aproveitamento de mão de obra interna.

Para atender os demais assuntos na opção 2 da URA, foram contratados dois profissionais, que cobriram o horário das 8 às $20 \mathrm{hs}$ de segunda a sábado. À noite e aos domingos, foram redirecionados profissionais internos. E para os primeiros 7 dias de operação assistida, foram treinamento outros 4 profissionais que receberiam os transbordos das chamadas caso o volume fosse muito superior à capacidade de atendimento da equipe dedicada.

Uma terceira ação tomada foi a definição de um líder para cada macroprocesso da operação: gestão de pacientes, intercorrência clínica, gestão de recursos, contas médicas, farmácia, logística e equipe médica. Dessa forma, alguém poderia acompanhar o aumento do volume de demandas ou alterações no tempo médio de resolução e, a partir dessas variações, tomar medidas para tornar $\mathrm{o}$ atendimento mais eficiente.

\subsubsection{Revisão da estrutura organizacional}

Segundo o diagnóstico da consultoria, a estrutura organizacional era altamente verticalizada, com posições características de corporações com volume muito maior de colaboradores que a realidade da empresa. Além disso, havia lideranças com responsabilidades redundantes e um volume de subordinados diretos que não se justificava, com muitas posições duplicadas. 
Todos os profissionais com nível de liderança tiveram interface com o trabalho de diagnóstico da consultoria e foram avaliados de acordo com os seguintes critérios:

1. Competência técnica e gerencial:

a. Capacidade técnica: conhecimentos e habilidades necessárias para desempenhar sua função.

b. Capacidade gerencial: capacidade de liderança de equipes e processos.

2. Motivação

a. Nível de motivação para liderar, implantar ou participar da implantação das melhorias e mudanças identificadas.

3. Impacto (no caso de a pessoa sair da estrutura da empresa)

a. Único detentor de conhecimentos importantes

b. Dificuldade de sucessão (com profissional de mercado ou de dentro da empresa)

c. Referência em valores e cultura organizacional

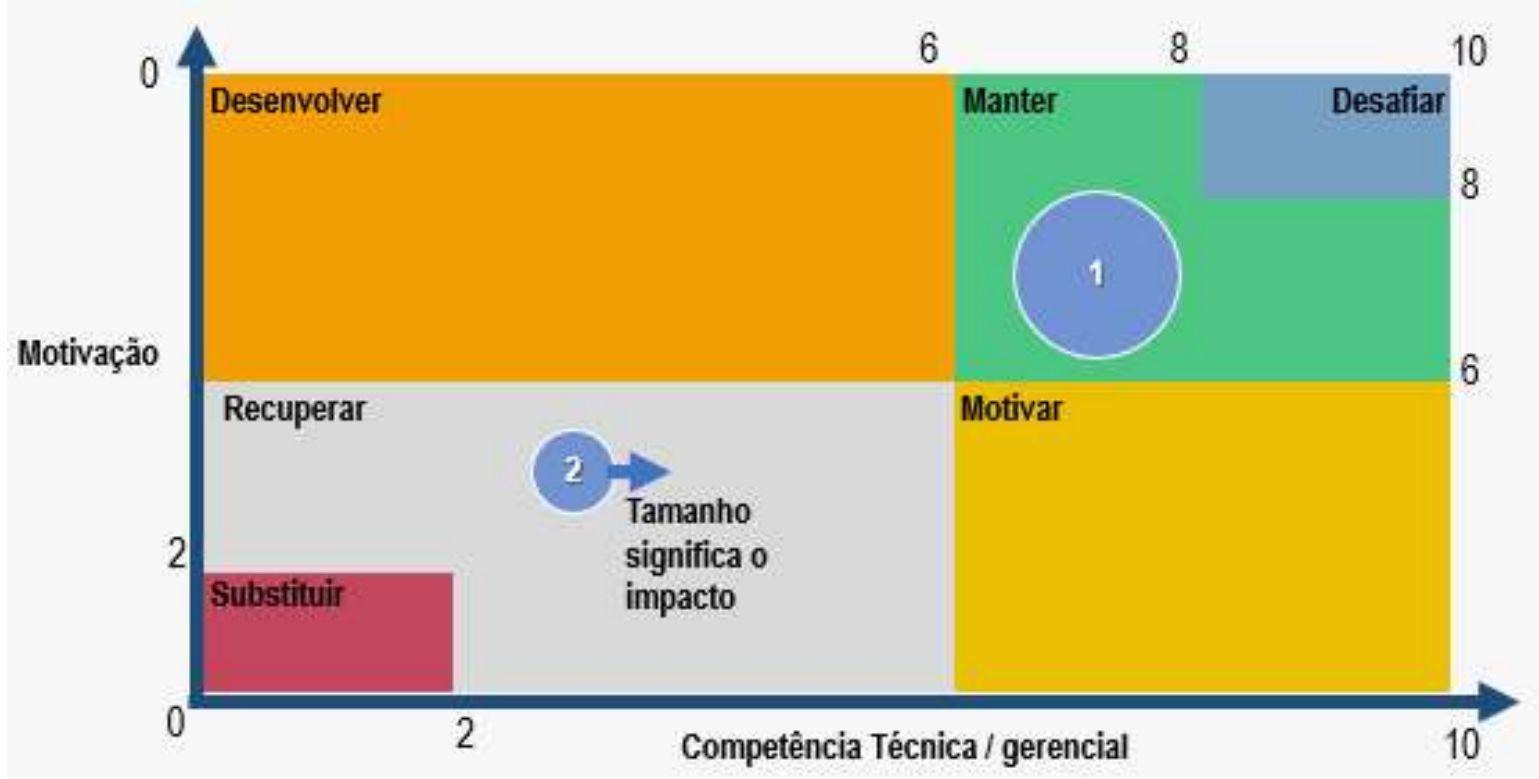

Figura 12. Matriz de análise de pessoas. Fonte: Relatório da Consultoria.

A Figura 20 demonstra os quatro quadrantes em que esses profissionais poderiam ser inicialmente classificados. No quadrante inferior esquerdo, 
estariam os profissionais com baixa capacitação técnica para a função ocupada e baixo grau de motivação para enfrentamento das mudanças necessárias. A recomendação para esses casos era a de criar um plano de recuperação e, na ausência do retorno esperado, efetivar a substituição. Já no quadrante superior direito, estavam os profissionais com elevado grau de capacitação e motivação e que, portanto, precisariam estar envolvidos em um plano de retenção, o que inclui mantê-los desafiados em suas funções. Os quadrantes intermediários incluem pessoas que atendem minimamente aos requisitos de suas funções, porém para alcançarem patamares de melhor entrega necessitariam de desenvolvimento, tanto técnico, quanto motivacional.

Utilizado o diagnóstico da consultoria como fonte de dados, e tendo concluído o levantamento de todas as atividades executadas pelas pessoas, deu-se início a etapa de análise das ações versus o perfil adequado para sua execução, objetivando a devida separação das atividades técnicas e operacionais. Além disso, calculou-se um tempo médio de atuação para cada uma delas, de forma que fosse possível estimar o número adequado de pessoas em cada equipe.

Constatou-se que muitas atividades administrativas (como solicitação de motoboy ou preenchimento de planilhas de controle) estavam sendo executadas por profissionais especialistas de nível superior, configurando um desperdício na alocação dos recursos.

Dessa forma, foi reavaliado o pessoal necessário, considerando a execução das demandas especializadas - que deveriam ser realizadas pelos profissionais de nível superior- e as demandas administrativas - a cargo dos profissionais com formação em nível médio. Essa reavaliação resultou nas seguintes mudanças:

- Redução da jornada semanal de 6 categorias profissionais de 44 para $36 \mathrm{hs}$ (total: $440 \mathrm{hs})$.

- $\quad$ Aumento de 220 hs horas da equipe administrativa (um recurso) para receber as atividades que estavam sendo executadas pela equipe técnica. 
- $\quad$ Diagnosticou-se também que uma mesma atividade era executada por diferentes profissionais, inseridos em várias equipes. Essa dispersão dificultava a gestão e não permitia sinergia de treinamento, acompanhamento e feedback para os executores.

Outro ponto relevante constatado foi a existência de uma grande sobrecarga de atividades em algumas equipes, especialmente nas que estavam diretamente ligadas ao relacionamento com os usuários. Optou-se, então, por redesenhá-las, de forma que fosse possível unificar atividades semelhantes, separando a interação com usuário e a interação com parceiros e fornecedores.

As Figuras a seguir apresentam a estrutura organizacional original e a nova estrutura organizacional proposta: 


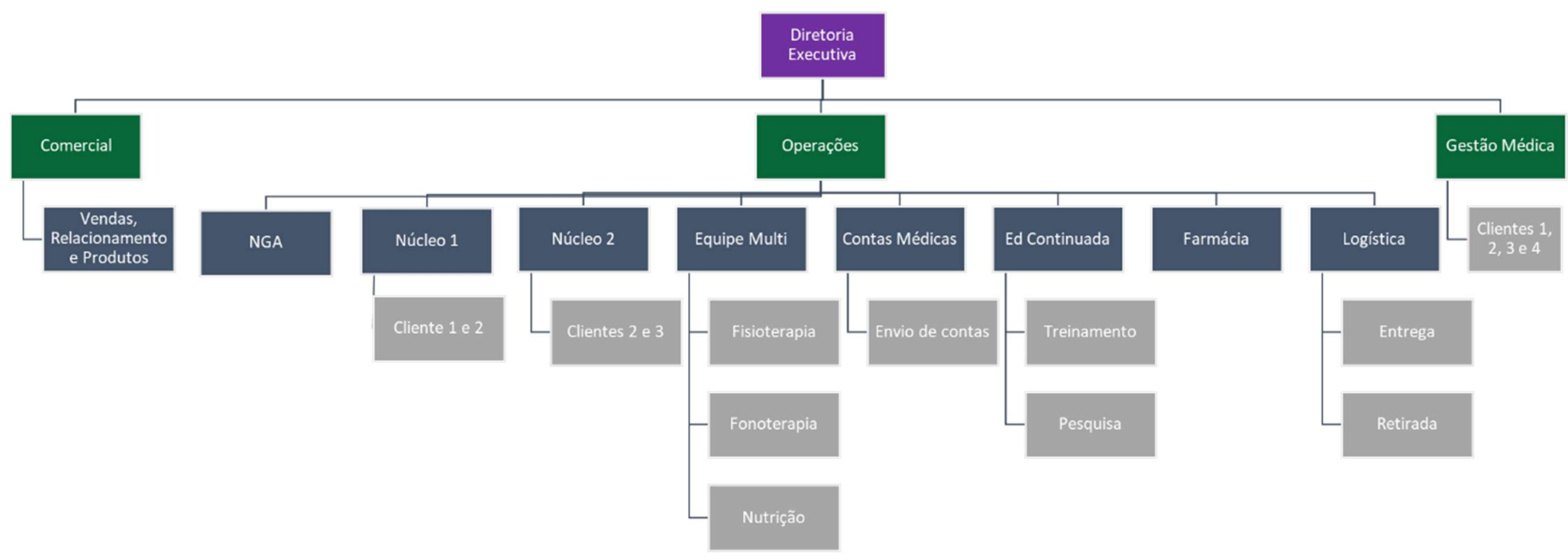

Figura 13. Estrutura atual das áreas. Fonte: elaborada pela autora. 


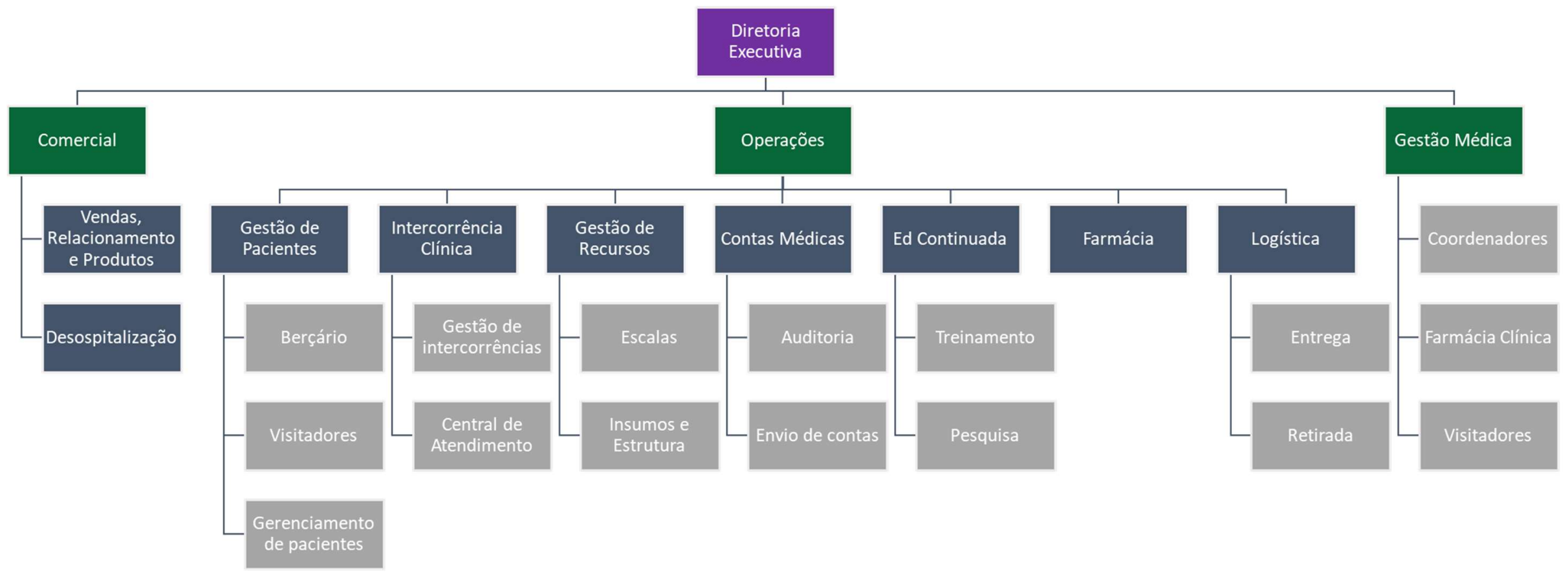

Figura 14. Estrutura proposta após a revisão das atividades. Fonte: elaborada pela autora. 
A estrutura original considerava a divisão das atividades por clientes e por categorias profissionais, como enfermeiros, fisioterapeutas, médicos etc. Demandas programadas ou eventuais não estavam separadas, e o resultado era uma equipe altamente reativa às demandas internas e pouco proativa na busca de soluções para os problemas dos usuários.

A nova estrutura organizacional proposta privilegiou as necessidades dos usuários e, por meio do bom atendimento a ele, acontecerá a entrega de um serviço adequado ao cliente. Sob essa perspectiva, foram considerados os diferentes momentos do usuário no relacionamento com a empresa e, a partir daí, agrupadas as atividades:

1. O primeiro momento ou desospitalização: é a fase da saída do hospital;

2. O segundo momento ou berçário: é a fase de adaptação do usuário aos serviços domiciliares;

3. Gerenciamento do usuário: é a fase que institui o relacionamento e conhecimento necessário para prestar uma assistência segura e adequada;

4. Foram segregadas as demandas não previstas e emergências, denominadas "Intercorrências clínicas". Isso porque, nessa condição, o usuário requer atendimento imediato e rápido. Evidenciou-se que, designando uma equipe exclusiva para esse tipo de atendimento, seria possível um atendimento mais ágil, desonerando as demais equipes das demandas emergenciais que, muitas vezes, ocupavam o lugar das demandas programadas e,

5. Criou-se uma equipe de relacionamento com fornecedores, que não atuam no relacionamento direto com usuário, porém trabalham nos bastidores, garantindo o cumprimento dos serviços contratados.

Vale ressaltar os aspectos culturais que interferiram na nova proposta de revisão de estrutura organizacional. Cultura organizacional, segundo Fleury e Fisher (1989), é composta pela união de elementos que, juntos, determinam a identidade organizacional, agindo como fatores de comunicação e consenso ou, em seu lado perverso, instrumentalizando as relações de dominação. 
Neste estudo, foram identificados alguns elementos culturais que podem influenciar a qualidade do atendimento aos usuários. Foram eles:

1. Ilhas de excelência: poucos colaboradores sendo nomeados pelos usuários como seus representantes internos, dado seu alto poder de resolutividade;

2. Criação de rótulos: usuários mais exigentes são rotulados como "famílias difíceis", situação essa que esconde as falhas de execução da equipe, minimizando sua responsabilidade em atender bem ao usuário;

3. Tomadas de decisão baseadas em percepção: as dificuldades na coleta de dados sobre a demanda real das residências geraram uma acomodação da equipe, que se acostumou a viver em um ciclo de aumento da demanda de trabalho e aumento frequente da insatisfação dos usuários. Isso propicia um ambiente cuja tomada de decisão é baseada nas percepções sobre a receptividade dos usuários, e não em informações claras sobre a criticidade das demandas;

4. Lentidão e falta de senso de urgência: a ausência de investigação sobre as causas dos principais problemas, com consequente falta de informação, não permite a priorização das ações. Dessa forma, tende-se a privilegiar o mais fácil de se executar, aumentando o índice de insatisfação do usuário e redução da qualidade da prestação de serviços.

5. Visão de mercado: empresas de assistência de saúde domiciliar em geral não compõem o ranking das melhores para se trabalhar, nem tampouco constam como opção de atuação profissional nos currículos escolares. Isso diminuiu a atração de bons profissionais, bem como a retenção daqueles que se destacam, que acabam buscando oportunidades similares em empresas de maior destaque no mercado.

Deal e Kennedy (1982) relatam bem o peso da cultura quando se quer propor uma mudança organizacional. Segundo os autores, durante essa mudança, é necessário que as pessoas se identifiquem com as novas regras e 
as novas lideranças que surgem. Dentro desse processo, as pessoas passam a contar diferentes histórias para explicar o novo ambiente do qual elas fazem parte. As horas produtivas são utilizadas de uma forma diferente, as dúvidas são outras e o resultado esperado também. Por essa razão, os autores orientam que todas as pessoas da organização sejam envolvidas nessa mudança, aumentando o engajamento e diminuindo a curva de aprendizado.

Holanda (1987), em um trabalho de investigação sobre a cultura brasileira, traz uma definição simples e fácil de compreender: "[...] Cultura é tudo que com o passar do tempo se incorpora na vida dos indivíduos, impregnando o seu cotidiano".

Segundo Kotter (2000), os líderes devem ter habilidades para apoiar a organização em momentos de crise, lidando com mudanças complexas, rompendo paradigmas e atuando na gestão de crises e conflitos. Tendo isso em vista, pontua-se que esse estudo apoiou a decisão da substituição de $100 \%$ do corpo diretivo, bem como de mais de $50 \%$ do quadro de gerentes e coordenadores. 


\section{Avaliação dos Resultados}

Ultrapassadas todas as barreiras, a central de atendimento ao usuário foi implantada em 11 de março de 2019, às 8hs.

Os primeiros 30 dias de adaptação ao novo modelo de atendimento foram bastante difíceis para todos. Isso porque, com a obrigatoriedade de registros no sistema de informação, ficou evidente que havia o dobro de demandas advindo das casas, e isso gerou uma grande sobrecarga de trabalho para a equipe, pois o volume de pessoas disponíveis para tratá-las foi considerado insuficiente. Os usuários também sentiram a diferença, pois estavam acostumados a serem atendidos por determinados representantes internos, e passaram a receber a informação de que a partir daquele momento as chamadas não seriam mais transferidas, e que as demandas seriam direcionadas para a equipe responsável, que oportunamente daria retorno. Isso também gerou uma certa resistência por parte deles.

A operação foi assistida de perto por uma equipe dedicada nos primeiros 7 dias após a mudança. Esses profissionais se posicionaram fisicamente perto da nova equipe de atendimento da central, bem como próximo aos demais elementos da equipe que dariam sequência à demanda recebida. O objetivo era o de minimizar a possibilidade de que algum usuário ficasse desassistido, ou que o tempo de resposta à demanda fosse alto, gerando algum tipo de insatisfação. Também foram destacados 5 profissionais que atenderiam ao excedente das ligações caso o volume fosse muito maior do que a capacidade da equipe dedicada.

Durante a operação assistida, identificou-se algumas oportunidades de revisão do planejamento da operação, como o reforço no treinamento dos profissionais da central e a revisão da recepção da demanda dentro das equipes de atendimento. Além disso, foi necessário revisitar todas as atividades da equipe, de forma que a nova demanda fosse acomodada, sem a necessidade de aumento do quadro de pessoal. Essas ações estão descritas na sequência. Esse diagnóstico permitiu uma análise para definição da necessidade de redimensionamento da equipe e revisão de processos, de forma que ações 
fossem tomadas junto as áreas mais afetadas pelos volumes de solicitações e se garantisse $o$ atendimento da demanda em menor tempo.

Para efeito de avaliação objetiva dos resultados, foram levantados dados nos 30 dias imediatamente anteriores e 30 dias imediatamente posteriores à mudança do processo segmentado para o unificado, período entre 9/2/2019 e 11/4/2019, extraídos das ocorrências registradas no sistema de informação utilizado nas operações. Cada demanda residencial deveria gerar o cadastro de uma ocorrência no sistema de informação. Importante ressaltar que a obrigatoriedade de registro de ocorrências no sistema em função das demandas já era uma regra, porém de controle e utilização bastante prejudicados em função da segmentação dos processos.

Tabela 7

Comparação nos volumes de registro de ocorrências

\begin{tabular}{|c|c|c|}
\hline PRÉ IMPLANTAÇÃO & PÓS IMPLANTAÇÃO & VARIAÇÃO \\
\hline 3.125 & 6.254 & $+100,1 \%$ \\
\hline
\end{tabular}

Nota: Fonte: elaborado pela autora.

As demandas que demonstraram a maior variação positiva estavam relacionadas aos processos descritos abaixo:

Tabela 8

Categorias com maior impacto em volume

\begin{tabular}{|l|c|c|c|}
\hline \multicolumn{1}{|c|}{ CATEGORIAS } & Volume PRÉ & Volume PÓS & Variação \\
\hline Escalas de técnicos de enfermagem & 174 & 598 & $343,7 \%$ \\
\hline Materiais e Medicamentos & 580 & 1533 & $264,3 \%$ \\
\hline Alterações de conduta médica & 92 & 214 & $232,6 \%$ \\
\hline $\begin{array}{l}\text { Solicitação de contato ao enfermeiro } \\
\text { CASE }\end{array}$ & 199 & 443 & $222,6 \%$ \\
\hline \begin{tabular}{l} 
Solicitação ou troca de mobiliários \\
\hline
\end{tabular} & 70 & 154 & $220,0 \%$ \\
\hline
\end{tabular}


Nota: Fonte: elaborado pela autora.

Observou-se uma variação enorme no volume de ocorrências registradas no sistema, aumento de 100,1\%. Esse resultado confirmou a suspeita de que muitas tratativas com os usuários, que consumiam tempo e recursos e possivelmente não seguiam padrões, não eram registradas como ocorrências no sistema. A descentralização na recepção da demanda por atendimento, a ausência de chamadas telefônicas gravadas e a faculdade de captar, armazenar e gerar informações informalmente, isto é, sem o registo no sistema de informação, não permitia a mensuração real do volume de ocorrências decorrentes das demandas por atendimento.

Os macroprocessos da operação que mais contribuíram para essa variação foram as Escalas de Técnicos de Enfermagem, Materiais e Medicamentos, Alterações na Conduta Médica, Solicitação de contato com a Enfermeira Case e Solicitação ou troca de mobiliários.

A equipe responsável por atender as demandas relacionadas às Escalas de Técnicos de Enfermagem é formada por uma coordenadora e sete técnicos para escalação de pessoal, compondo, portanto, uma equipe de oito profissionais, que trabalham das 7:00 às 20:00 horas, todos os dias da semana e aos finais de semana. Eles são responsáveis pelo relacionamento com as empresas que fornecem mão de obra para as escalas de cuidadores das residências, uma vez que essa atividade é terceirizada. Esse relacionamento inclui: formação das escalas de atendimento para novos usuários, substituição de profissionais das escalas fechadas, cobertura das folgas, cobertura das faltas, atrasos, apontamentos de problemas de conduta, relacionamento com as famílias dos usuários, entendimento dos perfis dos profissionais para cada perfil de usuário e família, fechamento das produtividades, aprovação das NF de serviços. Anteriormente ao funcionamento da central de atendimento, comunicados de atrasos, faltas, folgas programadas e as ligações de monitoramento das novas escalas não geravam registros no sistema. Por essa razão, houve um aumento tão significativo no volume de demandas. 
Materiais e medicamentos são dispensados para as residências pelo almoxarifado da empresa. A área solicitante é sempre a operação, e os volumes a serem solicitados consideram a prescrição médica e de cuidados, consumo diário e estoque. A solicitação é feita através de Ordem de Serviço (OS) em sistema e, dentro do Almoxarifado, passa pelos processos de separação e embalagem, para então seguirem para a residência. A área no sistema de informação que identifica a demanda, não é a mesma onde se registra o que foi dispensado e o que está pendente de dispensação. Por essa razão, quando os usuários entravam em contato com a empresa para verificar algum item, a informação era consultada no módulo de dispensação, resposta era dada imediatamente, sem registro no módulo de ocorrências. Essa dinâmica impedia que empresa tivesse conhecimento de quais eram os itens críticos que geravam maior demanda nas residências, e consequentemente eliminava a sua possibilidade de atuação sobre elas.

As ocorrências relacionadas à Alteração de Conduta Médica também não eram abertas, pois originalmente o meio de comunicação entre o médico que visita a residência e a equipe interna era o e-mail, e agora passou a ser inserido na ocorrência. Isso porque essas ocorrências ativam uma série de outras atividades internas como, por exemplo, solicitação de autorização pelo cliente, e todas elas também eram transacionadas por e-mail. Cabe ressaltar que essa equipe é composta por médicos coordenadores internos e médicos visitadores. As alterações de condutas médicas podem ser definidas pelas duas equipes, porém ocorre com muito mais frequência pela equipe de visitadores.

Denomina-se Enfermeira Case a profissional que centraliza os cuidados com o usuário, garantindo que toda a equipe que se relaciona com ele esteja atuando em sintonia, executando uma assistência adequada e segura. Na fase que antecedeu o funcionamento da central de atendimento, essas profissionais eram sobrecarregadas por demandas que não estavam dentro da sua esfera de atuação, isso porque elas se identificam como pontos focais de atendimento, e costumeiramente geram nos usuários fidelização e confiança. No cenário pós mudança, em que as ligações não eram transferidas pela central, os usuários passaram a solicitar mais contatos diretos com essa equipe, pois eles estavam acostumados a serem atendidos por ela. A expectativa é que esse volume de 
ocorrências solicitando contato com a enfermeira Case reduza com a adaptação e confiança dos usuários ao novo processo de atendimento.

Semelhante ao processo de atendimento e às escalas de técnicos em enfermagem, a equipe responsável pela Solicitação e Troca de Mobiliários também lida com os diversos fornecedores. Como toda a comunicação externa acontece por e-mail, as solicitações eram atendidas, porém não registradas adequadamente no sistema de informação. A ausência de informação aumenta a exposição ao erro e consequente desperdício na contabilização dos valores mensais a serem pagos.

Na fase que antecedeu o funcionamento da nova central de atendimento, o tempo médio para resolução das ocorrências era de 95hs, ou 4 dias. No primeiro mês de funcionamento da nova central, conforme apresenta a tabela a seguir, foi possível verificar uma mudança expressiva no tempo médio de atendimento das demandas.

Tabela 9

Variação no tempo de resolução das ocorrências

\begin{tabular}{|c|c|c|}
\hline PRÉ IMPLANTAÇÃO & PÓS IMPLANTAÇÃO & VARIAÇÃO \\
\hline 95 horas & 53,4 horas & $-43,7 \%$ \\
\hline
\end{tabular}

Nota: Fonte: elaborado pela autora.

As reclamações das residências são registradas no sistema de informação como ocorrência e classificadas como "Reclamação", cresceram. No quadro abaixo, é possível comparar os volumes de reclamações na fase pré e pós implantação da central de acolhimento. 
Tabela 10

Variação no registro das Reclamações

\begin{tabular}{|c|c|c|}
\hline PRÉ IMPLANTAÇÃO & PÓS IMPLANTAÇÃO & VARIAÇÃO \\
\hline 98 & 152 & $+55,1 \%$ \\
\hline
\end{tabular}

Nota: Fonte: elaborado pela autora.

O percentual da variação no registro das reclamações foi $44,9 \%$, inferior à variação total dos registros, que foi de 100,1\%. A Tabela abaixo demonstra a variação do volume de reclamações nas principais categorias das ocorrências:

Tabela 11

Variação do registro das Reclamações por categoria

\begin{tabular}{|l|c|c|c|}
\hline CATEGORIAS & Volume PRÉ & Volume PÓS & Variação \\
\hline Materiais e Medicamentos & 18 & 51 & $183,3 \%$ \\
\hline Fisioterapeuta & 8 & 16 & $100,0 \%$ \\
\hline Escalas de técnicos de enfermagem & 26 & 36 & $38,5 \%$ \\
\hline Fonoaudiólogo & 7 & 7 & $0,0 \%$ \\
\hline Enfermeira CASE & 15 & 12 & $-20,0 \%$ \\
\hline Médico & 9 & 5 & $-44,4 \%$ \\
\hline
\end{tabular}

Nota: Fonte: elaborado pela autora.

Demandas relacionadas a materiais e medicamentos ocupam a segunda maior demanda de chamadas, e primeira causa de reclamações. O processo de atendimento explica esse resultado, uma vez que a assistência acontece longe da estrutura de dispensação dos insumos e o tempo previsto da entrega nem sempre atende às expectativas dos usuários.

As categorias não relacionadas a materiais e medicamentos que aparecem na lista das maiores causas de reclamações, estão ligadas à atuação das equipes de atendimento em suas diversas especialidades. Fisioterapeutas, Técnicos de Enfermagem e Fonoaudiólogos são os profissionais mais frequentes nas escalas de assistência no domicílio. Enfermeiros e Médicos têm atuação menos intensa e são categorias profissionais com dois representantes, 
um interno e um externo, permitindo uma comunicação mais rápida e coordenada com o usuário. A logística de atendimento nas residências, causadora de atrasos e ausências, e o fator empatia, responsável pela aceitação do profissional pelo usuário influenciam muito nesse aspecto. Percebeu-se que a solicitação de troca do profissional vem seguida de uma reclamação sobre um desses aspectos. 


\section{Conclusões}

No mestrado profissional deve ocorrer a imersão na pesquisa, porém deseja-se aprimorar a formação do profissional, externo a academia, na sua habilidade de reconhecer, identificar e utilizar a pesquisa para agregar valor as suas atividades profissionais ou sociais. As diretrizes de um estudo em um mestrado profissional são orientadas por um problema encontrado na prática profissional e o pesquisador deve encontrar as propostas de solução por meio do emprego de um método de pesquisa.

O principal resultado deste estudo de caso foi, através da visão de mudança por processos, gerar uma contribuição efetiva para a empresa estudada, confirmando o mestrado profissional como formador de pesquisadores que no campo profissional desenvolvam a habilidade de reconhecer, identificar e utilizar a pesquisa para agregar valor as suas atividades profissionais.

O presente trabalho teve a finalidade de estudar a renovação dos processos de atendimento ao usuário, tendo como resultados esperados 0 aumento de eficiência, refletido nos tempos médios de atendimento aos usuários e na diminuição de custos, com a redução do custo com pessoas e aumento da satisfação do usuário, medida pelo volume de apontamentos na Ouvidoria. Seu principal resultado, entretanto, foi empreender mudanças e renovações em processos críticos da organização estudada, comprovando a possibilidade de aplicar na prática uma efetiva gestão por processos, que possibilitou aumento de eficiência e a possibilidade de redução de custos, fatores fundamentais para a sobrevivência da empresa.

O atual cenário do sistema de saúde também impulsionou a realização dessa pesquisa. Considerando que todo o sistema é formado pela união de empresas que as representam, é válido pensar que a busca por mais eficiência e satisfação presentes nesse trabalho podem servir de estímulo para que todo o sistema se reavalie e entenda quais mudanças são necessárias para o alcance do cenário esperado. 
A gestão por processos é um tema que tem sido amplamente discutido em várias indústrias, e analisar as operações de saúde sob essa perspectiva direciona esse setor para o caminho da sustentabilidade e da entrega de valor para os usuários.

O sucesso na implantação da central de atendimento ao usuário aumentou o nível de confiança da equipe. Isso permitirá a continuidade da reestruturação iniciada, assim como a manutenção de uma busca continua por eficiência e qualidade.

É possível concluir que os objetivos propostos para esse trabalho foram alcançados. Houve aumento da eficiência, medido pelo aumento das ocorrências resolvidas em menor tempo e consequente diminuição do custo por ocorrência atendida. Porém, não foi possível identificar elementos suficientes para afirmar que a satisfação do usuário aumentou.

Outro ganho relevante que essa pesquisa proporcionou à empresa estudada foi a especificação de requisitos para o sistema de informação em implementação, que beneficiará todo o processo de atendimento ao usuário e permitirá ainda maior ganho de eficiência.

Não foi possível mensurar e avaliar o impacto dessa mudança na percepção dos clientes. Acredita-se que o aumento de eficiência obtido no atendimento aos usuários colocará a empresa à frente de seus concorrentes, porém esse será um efeito de médio prazo.

Essa pesquisa também colaborou para o desempenho profissional da autora, que através do aprendizado adquirido com a teoria pesquisada, a metodologia utilizada e os resultados obtidos, potencializará sua atuação profissional com a visão de pesquisadora, contribuindo ainda mais para a empresa em que atua e para a área de gestão da saúde como um todo.

As limitações dessa pesquisa estão relacionadas ao fato dela ter transcorrido em um ambiente organizacional único, o que restringe a possibilidade de generalizar a análise para além dos resultados da própria pesquisa. Adicionalmente a esse fato, ainda dentro do ambiente organizacional, essa pesquisa transcorreu na área de Operações, o que pode ter influenciado 
as conclusões, uma vez que essa área traz seu olhar para o usuário e para todas as suas complexidades e particularidades.

\section{Referencial Bibliográfico}

ABPMP - Associação Internacional de Profissionais de BPM. (2013). BPM CBOK - Guia para o gerenciamento de processos de negócio. Recuperado de <http://www.abpmp-br.org/bpm-cbok-v3-0/>.

Albuquerque, L. G., A (2002) Gestão Estratégica de Pessoas. In: Fleury, M. T. L. As pessoas nas organizações. São Paulo: Gente, 2002.

ANS - Agência Nacional de Saúde. (2009). Manual técnico de promoção da saúde e prevenção de riscos e doenças na saúde suplementar (3. ed. rev. e atual.). Rio de Janeiro: ANS.

ANS - Agência Nacional de Saúde. (2014). ANS define regras para a remoção de pacientes de planos de saúde com cobertura hospitalar. 04 de abril. Recuperado de <http://www.ans.gov.br/a-ans/sala-de-noticiasans/consumidor/2447-ans-define-regras-para-a-remocao-de-pacientes-deplanos-de-saude-com-cobertura-hospitalar>.

ANS - Agência Nacional de Saúde. (2016). Parecer Técnico No 04/GEAS/GGRAS/DIPRO/2016. Cobertura: Assistência Domiciliar (Home Care). Recuperado de http://www.ans.gov.br/images/stories/parecer_tecnico/uploads/parecer_tecn ico/_parecer_2016_04.pdf.

ANS - Agência Nacional de Saúde. (2018). Sala de situação. ANS. Recuperado de <http://www.ans.gov.br/perfil-do-setor/dados-e-indicadores-dosetor/sala-de-situacao>.

Antunes, A. V., \& Trevizan, M. A. (2000). Gerenciamento da qualidade: utilização no serviço de enfermagem. Revista Latino-Americana de Enfermagem, 8(1),35-44.

Bergue, S. T. (2014) Gestão Estratégica de Pessoas no Setor Público. Ed. Atlas. SP.

Berry, L.L., Mirabito, A. M., Baun, W. B. (2010). What's the Hard Return on Employee Wellness Programs? Harvard Business Review, December 2010.

BPM CBOK (2009). Business Process Management Common Body of Knowledge. Versão 2.0, 325p.

Brasil. Projeto de Lei No 5.088-B, de 04 de março de 2013. Torna obrigatória a permanência de ambulância de resgate e de profissional da área da saúde em lugares com grandes aglomerações de pessoas. [Aprovado em 
11/11/2014]. Recuperado de

$<$ http://www.camara.gov.br/proposicoesWeb/fichadetramitacao?idProposica $0=566255>$.

Burns LR, Degraaf RA, Danzon PM, Kimberly JR, Kissik WL, Pauly MV. (2002) The Wharton School study of the health care value chain. In: Burns LR, editor. The health care value chain: producers, purchasers and providers. San Francisco: Jossey-Bass; 2002. p. 3-26.

Campos EF, Gontijo MCF, Oliveira PJ, Chaves SR, Laudares P, editores. (2009) A cadeia de valor em saúde: uma proposta de reorganização da atenção na saúde suplementar. Belo Horizonte: Unimed Federação Minas; 2009.

Campos, C. E. A.; Garcia, J. (2007) Contribuições para a supervisão dos programas sociais com foco na família. Revista Katálisys, v.10, n.1, p.95104, jun. 2007.

Candido, R. M., Ferreira, M. T., \& Zuhlke, R. F. (2008) Implantação de Gestão por Processos: Estudo de Caso numa Gerência de um Centro de Pesquisas, Rio de Janeiro. Anais XXVIII Encontro Nacional de Engenharia de Produção (ENEGEP), Rio de Janeiro, 2008.

Christensen, M. C., Grossman, J. H., \& Hwang, J. (2009). Inovação na Gestão da Saúde - A receita para reduzir custos e aumentar qualidade. Porto Alegre: Bookman, 2009.

Cogan, S. (1994). Activity Based Costing (ABC) - A Poderosa Estratégia Empresarial. São Paulo: Pioneira.

Cohn, A., \& Elias, P. E. (2003). Saúde no Brasil: políticas e organização de serviços. São Paulo: Editora Cortez.

Collucci, C. (2017). Disparam decisões que obrigam planos de saúde a oferecer serviço home care. Folha de S. Paulo, 11 de abril. Recuperado de http://www1.folha.uol.com.br/cotidiano/2017/04/1874421-disparam-decisoes-queobrigam-planos-de-saude-a-oferecer-servico-home-care.shtml.

COUGHLAN, P.; COGHLAN, D. (2002) Action Research For Operations Management. International Journal of Operations \& Production Management, v. 22, n. 2, p. 220240.

Creswell, J. W. W. Projeto de pesquisa: métodos qualitativo, quantitativo e misto. 2. ed. Porto Alegre: Bookman, 2010.

Deal, Terrence E.; Kennedy, Allen A. (1982) Corporate cultures: The rites and rituals of corporate life. Readin: Addison-Wesley, 1982.

Debruin, T., \& Doebeli, G. (2009) BPM as an organizational approach: the experience of an Australian transport provider. In: Rosemann, M., \& Von Brocke, J. (Eds.). Handbook on Business Process Management. (vol. 1). Berlin: Springer, 2009. 
Deslandes, S. F. (2004). Análise do discurso oficial sobre a humanização da assistência hospitalar. Ciência \& Saúde Coletiva, 9(1),7-14.

ENGEL, G. I. (2000) Pesquisa-ação. Educar em Revista, n. 16, PP.181-191. Universidade Federal do Paraná. Paraná. Brasil. P.3-4.

Enthoven AC. (2008) Curing fragmentation with integrated delivery systems: what they do, what has blocked them, why we need them, and how to get there from here. Presentation at the Harvard Law School Conference: "Our Fragmented Health Care System: Causes and Solutions." June 13-14, 2008.

Ferreira, A. B. H. (1975). Novo dicionário da língua portuguesa (15 reimp.). Rio de Janeiro: Nova Fronteira.

Feuerwerker, L. C. M., \& Merhy, E. E. (2008). A contribuição da atenção domiciliar para a configuração de redes substitutivas de saúde: desinstitucionalização e transformação de práticas. Revista Panamericana de Salud Pública, 24(3):180.

Fleury, M. T. L., Fischer, R. M. (1989) Cultura e Poder nas Organizações. São Paulo: Atlas, 1989.

Flick, U. Desenho da pesquisa qualitativa. Porto Alegre: Artmed, 2009.

Folha de S. Paulo. (2016). Saúde supera corrupção como pior problema para a população. Folha de S. Paulo, São Paulo, 11 de dezembro. Recuperado de <http://www1.folha.uol.com.br/poder/2016/12/ 1840371-saude-superacorrupcao-como-pior-problema-para-a-populacao.shtml>.

Fundação Oswado Cruz. (2012). A Saúde no Brasil em 2030: diretrizes para prospecção estratégica para o sistema de saúde brasileiro. Rio de Janeiro: Fiocruz/Ipea/Ministério da Saúde/Secretaria de Assuntos Estratégicos da Presidência da República.

Gadelha CAG. (2003) O complexo industrial da saúde e a necessidade de um enfoque dinâmico na economia da saúde. Cien Saude Colet 2003; $8(2): 521-535$

Gil, A. C. (2008). Métodos e técnicas de pesquisa social. São Paulo: Atlas.

Gil, A.C. (1995). Como elaborar projetos e pesquisa. São Paulo: Atlas.

Godoy, A. S. (1995). Introdução à pesquisa qualitativa e suas possibilidades. RAE - Revista de Administração de Empresas, São Paulo, 35(2), 57-63.

Gonçalves, J. E. L. (2000, out-dez.). Processo, que processo? RAE - Revista de Administração de Empresas, São Paulo, 40(4), 8-19.

Graham, Morris, LeBaron, Melvin. (1994) The horizontal revolution. San Francisco: Jossey-Bass, 1994. 
Hair, J., Babin, B., Money, A., \& Samouel, P. (2005). Fundamentos de Métodos de Pesquisa em Administração. São Paulo: Bookman.

Hammer, M. (1998) A empresa voltada para processos. Management, jul./ago. 1998.

Hammer, M., \& Champy, J. (1994). Reengineering the corporation. New York: Harper Business.

Harrington, H. J. (1991). Business process improvement. New York: McGraw Hill.

Hartz, Z.M. Z, Contandriopoulos, (2004) A. Integralidade da atenção e integração de serviços de saúde: desafios para avaliar a implantação de um "sistema sem muros" - Cad. Saúde Pública, Rio de Janeiro, 20 Sup 2:S331-S336, 2004.

Herzlinger RE. (2007) Who killed health care? America's \$2 trillion medical problem - and the consumer-driven cure. New York: McGraw-Hill; 2007.

Holanda, Sérgio Buarque de (1936-69) Raízes do Brasil. Rio de Janeiro: José Olympio Editora, 1987. Primeira edição, 1936; quinta edição, texto definitivo, 1969.

Houaiss, A. (2001). Dicionário Houaiss da língua portuguesa. São Paulo: Objetiva.

Jesus, L., \& Macieira, A. (2015) Repensando a gestão por meio de processos. Rio de Janeiro: Algo Mais, 2015.

Koladycz, R. Fernandez,G., Gray, K., Marriott, H. (2018) Global Health: Science and Practice October 2018, 6(3):413424; https://doi.org/10.9745/GHSP-D-18-00068

Kotter, J. (2000) Afinal, o que fazem os líderes: a nova face do poder e da estratégia. Rio de Janeiro: Campus, 2000.

Machado, C. V., Salvador, F. G. F., \& O'Dwyer, G. (2011). Serviço de Atendimento Móvel de Urgência: análise da política brasileira. Revista Saúde Pública, 45(3),519-528.

Malvestio, M. A. A., \& Sousa, R. M. C. (2002). Suporte avançado à vida: atendimento a vítimas de acidentes de trânsito. Revista Saúde Pública, 36(5),584-589.

Martins, P.G., Laugeni FP. (1999) Administração da produção. São Paulo: Saraiva; 1999.

Maximiniano, A. C. A. (2004) Introdução à Administração. - 6 ed. rev. e atual. São Paulo: Atlas, 2004. 
Mello, C. H., Turrioni, J. B., Xavier, A. F., \& Campos, D. F. (2012). Pesquisa ação na engenharia de produção: proposta de estruturação para sua condução. Produção, pp. 22(1), 1-13.

Michell, M. (2009). Complexity: A guided tour. Oxford: Oxford University Press.

Ministério da Saúde. (2016). Recuperado de $<$ http://portalarquivos2.saude.gov.br>.

Ministério da Saúde. Portaria $n^{\circ} 741 / G M$, de 19 de dezembro de 2005, com Anexos: Definem as Unidades de Assistência de Alta Complexidade em Oncologia, os Centros de Assistência de Alta Complexidade em Oncologia (CACON) e os Centros de Referência de Alta Complexidade em Oncologia e suas aptidões e qualidades e inclui outras providências. Diário Oficial [da] União, Brasília, DF, dez. 23 2005b. Seção 1, p. 113.

Monteiro, R. (2010) Busca e Retenção. In: Gestão Estratégica de Pessoas: Conceitos e Tendências. S.P., Ed. Saraiva, 2010

Net Promoter Score. Recuperado de $<$ http://www.netpromotersystem.com/about/ measuring-your-net-promoterscore.aspx>.

OPAS - Organização Pan-Americana de Saúde. (2011). Doenças Crônicas Não Transmissíveis: Estratégias de Controle e Desafios para os Sistemas de Saúde. Brasília: OPA.

Orlova A.O., Dunnagan, M., Finitzo, T., Higgins, M., Watkins, T., Tien, A., et al. (2005) Electronic health record - public health (EHR-PH) system prototype for interoperability in 21st century healthcare systems. AMIA Annu Symp Proc. 2005:575-9

Ostroff, F., (1999) The horizontal organization. Oxfordm, 1999.

Paim, J., Travassos, C., Almeida, C., Bahia, L., \& Macinko, J. (2011). O sistema de saúde brasileiro: história, avanços e desafios. Lancet, 377(9779),17781797.

Paim, R., Cardoso, V., Caulliraux, H, \& Clemente, R. (2009) Gestão de processos: pensar, agir e aprender. Porto Alegre: Bookman, 2009.

Pedroso MC, Malik AM. (2012) Healthcare value chain: a model for the Brazilian healthcare system. Ciênc Saúde Coletiva. 2012; 17(10):2757-72.

Pisano GP. (2006) Science business: the promise, the reality and the future of biotech. Boston: Harvard Business School Press; 2006.

Por que pesquisa em Saúde? Council on Health Research for Development (COHRED) Global Forum for Health Research. Brasilia: 2007.

Porter, M. E. (1996, nov-dez.). What is Strategy? Harvard Business Review, 6178. Recuperado 
https://pdfs.semanticscholar.org/62a5/6cb47ec0a181da67358662446ab7d5 44c01f.pdf.

Porter, M.E., Teisberg E.O. (2006) Redefining Health Care: Creating ValueBased Competition on Results (Boston: Harvard Business School Press)

RESOLUÇÃO CFM No 2.110/2014 (Publicada do D.O.U. em 19 nov. 2014, Seção I, p. 199).

Robbins. S.P. (1990) Organizational Behavior. Englewood Cliffs, NJ: Pretince hall.

Rodrigues, K.C. (2019) A era da experiência dos pacientes. GVEXECUTIVO • V $18 \cdot \mathrm{N} 1 \cdot \mathrm{JAN} / \mathrm{FEV}$ 2019. FUNDAÇÃO GETULIO VARGAS.

Shingo, S. (1996). O sistema Toyota de Produção - do ponto de vista da engenharia da produção. Porto Alegre: Bookman.

Slack, N., Chambers, S., \& Johnston, R. (2009). Administração da Produção (3a ed.). São Paulo: Atlas.

Thiollent, M. (2011). Metodologia da Pesquisa Ação. São Paulo: Cortez.

Torres Júnior, N., \& Miyake, D. I. (2011). Melhoria de desempenho em serviços: alternativas para lidar com o trade-off entre eficiência e eficácia. Revista Produção Online, 11(1), 162-193.

Tushman M., Nadler, D. (1997) Organizando-se para a inovação In: STARKEY, Ken. Como as organizações aprendem: relatos do sucesso das grandes empresas. São Paulo: Futura, 1997.

Veras, R. P. (2012). Gerenciamento de doença crônica: equívoco para o grupo etário dos idosos. Revista Saúde Pública, 46(6),929-934.

Vidor, A. C., Fischer, P.D., Bordin, R. (2011). Utilização dos sistemas de informação em saúde em municípios gaúchos de pequeno porte. Revista Saúde Pública, 45(1),24-30

Walliman, N. (2015). Métodos de Pesquisa. São Paulo: Saraiva.

Yin, R. (2001) Estudo de caso: planejamento e métodos. Porto Alegre: Bookman. 